\title{
Neolithic and Eneolithic activities inferred from organic residue analysis of pottery from Mala Triglavca, Moverna vas and Ajdovska jama, Slovenia
}

\author{
Lucija Šoberl $^{1 \%}$, Milena Horvat ${ }^{2}$, Andreja Žibrat Gašparič $^{2}$, Marko Sraka $^{2}$, \\ Richard Evershed ${ }^{1}$ and Mihael Budja ${ }^{2}$ \\ 1 Organic Geochemistry Unit, School of Chemistry, University of Bristol, UK \\ lucija.soberl@gmail.com \\ 2 Department of Archaeology, Faculty of Arts, University of Ljubljana, SI
}

\begin{abstract}
The research discussed in this paper focused on the analysis and identification of organic residues either preserved as visible or absorbed organic remains on Neolithic and Eneolithic pottery from various archaeological and geographical contexts. These are connected with various food preparation strategies and past human activities, i.e. cave burials in Ajdovska jama (food as a grave good/offering), the rock shelter at Mala Triglavca (meat and dairy animal husbandry practices) and Moverna vas, which had a long occupation sequence (complex farming and animal management). The preservation of biomarkers mirrored past human activities and different pottery uses at various types of sites. The carbon stable isotope ratios of primary fatty acids in lipid pottery extracts confirmed the presence of adipose and dairy fats as well as biomarkers of plant fats, beeswax and birch bark tar.

IZVLEČEK - Predstavljeno raziskovalno delo se je osredotočalo na analizo in identifikacijo organskih ostankov na površini neolitske in eneolitske keramike ter ostankov lipidov absorbiranih v keramično matrico vzorcev iz različnih arheoloških in geografskih kontekstov. Ti so povezani z različnimi strategijami priprave hrane in preteklimi človeškimi aktivnostmi - pokopi v Ajdovski jami (hrana kot grobni pridatek), skalni previs Mala Triglavca (mesna in mlekarska živinoreja) ter naselbina Moverna vas z dolgo stratigrafsko sekvenco (kompleksno poljedelstvo in živinoreja). Različne tipe najdišč je bilo mogoče povezati z raznolikimi dejavnostmi in raznoliko uporabo keramičnih posod prek ohranjenih biomarkerjev. Analiza razmerja stabilnih izotopov glavnih maščobnih kislin v keramičnih ekstraktih je potrdila prisotnost mesnih in mlečnih maščob glavnih domestikatov kakor tudi navzočnost lipidnih biomarkerjev rastlinskega izvora, ostanke čebeljega voska in smole.
\end{abstract}

KEY WORDS - Neolithic; Eneolithic; lipid residue analysis; pottery; stable isotopes; birch bark tar; beeswax

\section{Introduction}

Archaeological research has benefited greatly in the past twenty years from an exponential increase in interdisciplinary studies incorporating analytical sciences. Two major fields of archaeological investigation, predominantly in prehistoric periods, have been trying to understand past diets and the mobility of populations by analysing osteological material and ceramics. The porous surface of these two commonly found archaeological artefacts enables organic molecules such as lipids, proteins and nucleic acids to become entrapped and preserved through millennia.

Unglazed pottery has proved to be an ideal analytical medium: on the one hand, it readily absorbs organic compounds during cooking, food storage and consumption, while it also serves as an indicator of past lifestyles, kinship, animal husbandry practices,

* author for correspondence 
agriculture, trade or ritual practices (Boast 2002; Gibson 2002). Although organic molecules are prone to degradation processes during pottery use or during the post-depositional period, it has been found that adequate concentrations of lipids can be preserved either as absorbed residues or visible food crusts and retrieved through organic solvent extraction (Heron, Evershed 1993; Evershed 2008; Craig 2004; Saul et al. 2013).

\section{Sites selection}

Among the various Slovenian Neolithic and Eneolithic sites available, three were chosen for lipids analy-

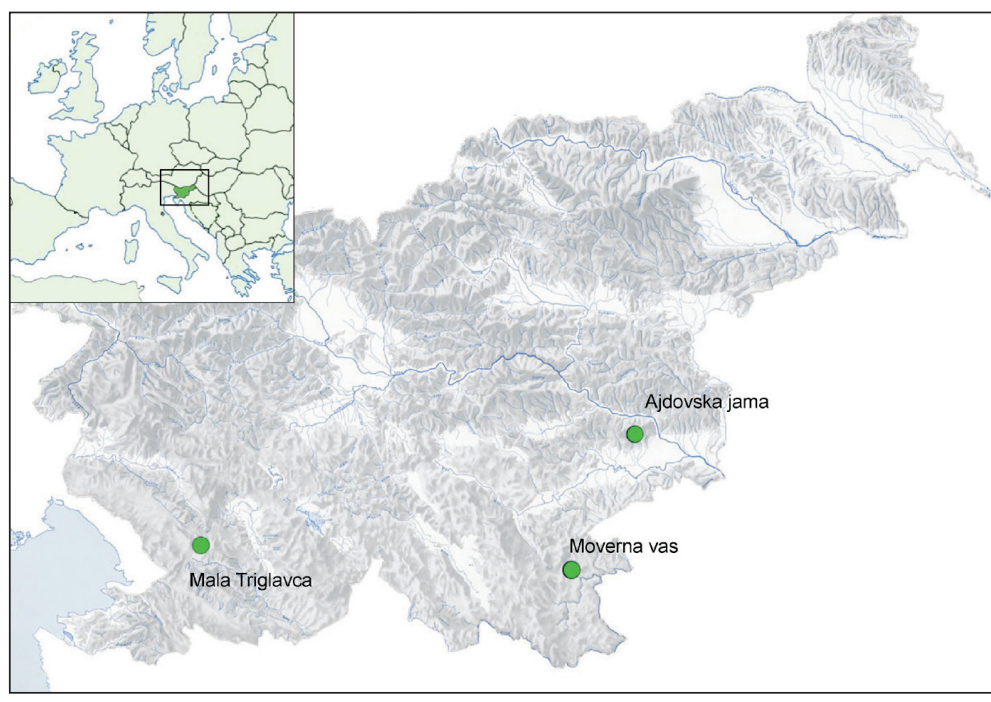

Fig. 1. A map of Slovenia showing the locations of archaeological sites investigated (adapted from National Museum of Slovenia). ses (Fig. 1). The two with the longest settlement sequence, i.e. Mala Triglavca and Moverna vas, are embedded in different environmental and cultural contexts. The third, Ajdovska jama, is a burial site with strong evidence of burial ceremonies and rituals.

The Mala Triglavca rock shelter is located on the Dinaric Karst in south-western Slovenia, $15 \mathrm{~km}$ from the Northern Adriatic coast. The AMS ${ }^{14} \mathrm{C}$ dates show a long sequence of human activities from the $8^{\text {th }}$ to the $3^{\text {rd }}$ millennium calBC, combined with natural and geomorphological post-depositional disturbances. The Moverna vas open-air site is situated in the karstified Bela Krajina region in the south-eastern part of Slovenia. The settlement sequence spans approximately two millennia from the $5^{\text {th }}$ to the $3^{\text {rd }}$ millennium calBC. The Ajdovska jama cave site lies within the catchment of the Sava River in south-eastern Slovenia. The site is well known for its burials. The human remains at the site occurred as distinct clusters of mainly disarticulated bones belonging to at least 31 individuals. The cave was used for burial and related ritual practices in the late $5^{\text {th }}$ and early $4^{\text {th }}$ millennium calBC.

\section{Moverna vas}

The Neolithic and Eneolithic settlement sequence at Moverna vas consists of nine settlement phases. Phases 2 to 6 were recognised as Neolithic, and phases 7 to 9 as Eneolithic (Budja 1989; 1994). Bayesian modelling (Fig. 2) shows that the sequence spans approximately two millennia, with continuous occupation from $4945-4810$ calBC to $4270-4135$ calBC and discontinuous occupation until 2905-2800 calBC (at $68.2 \%$ probability) with possibly centuries-long breaks in occupation (Budja 1994; Sraka 2013). The chronology is largely based on AMS ${ }^{14} \mathrm{C}$ dates from carbonised organic residues adhering to interior pottery surfaces. Chemical analyses of these residues show that they are either charred remains of food

\begin{tabular}{|c|c|c|c|c|c|c|c|c|c|}
\hline $\begin{array}{l}\text { Sample } \\
\text { Name }\end{array}$ & Material & Context & Phase & Lab code & $\begin{array}{l}\text { 14C Con- } \\
\text { ventional } \\
\text { age }(B P)\end{array}$ & $\begin{array}{l}\text { Calibrated age } \\
\text { acc. to } 68.2 \% \\
\text { prob. (calBC) }\end{array}$ & $\begin{array}{l}\text { Calibrated age } \\
\text { acc. to } 95.4 \% \\
\text { prob. (calBC) }\end{array}$ & $\begin{array}{c}\Delta^{13} \mathrm{C} \\
\text { (meas. } \\
\text { on AMS) }\end{array}$ & Reference \\
\hline $23 \mathrm{MV}$ & food crust & 053.1 & 3 & Poz-21396 & $5750 \pm 40$ & $4450-4350$ & $4460-4335$ & $-24.9 \pm 0.5$ & Sraka 2013.App. \\
\hline $24 \mathrm{MV}$ & birch bark tar & 050.2 & 4 & Poz-21398 & $5550 \pm 40$ & $4540-4455$ & $4615-4370$ & $-20.6 \pm 0.3$ & Sraka 2013.App. \\
\hline $25 \mathrm{MV}$ & birch bark tar & 050.1 & 4 & Poz-21399 & $5630 \pm 40$ & $4715-4605$ & $4770-4540$ & $-24.2 \pm 0.2$ & Sraka 2013.App. \\
\hline $26 \mathrm{MV}$ & birch bark tar & O22.1 & 5 & Poz-21400 & $5610 \pm 40$ & $4940-4805$ & $4995-4785$ & $-24.2 \pm 0.6$ & Sraka 2013.App. \\
\hline $27 \mathrm{MV}$ & birch bark tar & 050.1 & 4 & Poz-21401 & $5620 \pm 40$ & $4495-4370$ & $4530-4360$ & $-20 \pm 0.4$ & Sraka 2013.App. \\
\hline $28 \mathrm{MV}$ & birch bark tar & $050.2 / 056$ & 2 & Poz-21402 & $5990 \pm 40$ & $4490-4365$ & $4520-4355$ & $-22.3 \pm 0.7$ & Sraka 2013.App. \\
\hline $29 \mathrm{MV}$ & food crust & planum 7 & 2 & Poz-21403 & $5800 \pm 40$ & $4505-4370$ & $4540-4365$ & $-21.6 \pm 1.8$ & Sraka 2013.App. \\
\hline $151 \mathrm{MV}$ & birch bark tar & 031.4 & 6 & Poz-21404 & $5670 \pm 40$ & $4450-4350$ & $4460-4335$ & $-19.1 \pm 0.5$ & Sraka 2013.App. \\
\hline $152 \mathrm{MV}$ & birch bark tar & 050.2 & 4 & Poz-21420 & $5550 \pm 40$ & $4680-4545$ & $4705-4500$ & $-22.9 \pm 0.5$ & Sraka 2013.App. \\
\hline
\end{tabular}

Tab. 1. ${ }^{14}$ C dates obtained from organic remains on pottery for Moverna vas (see also Fig. 10). 


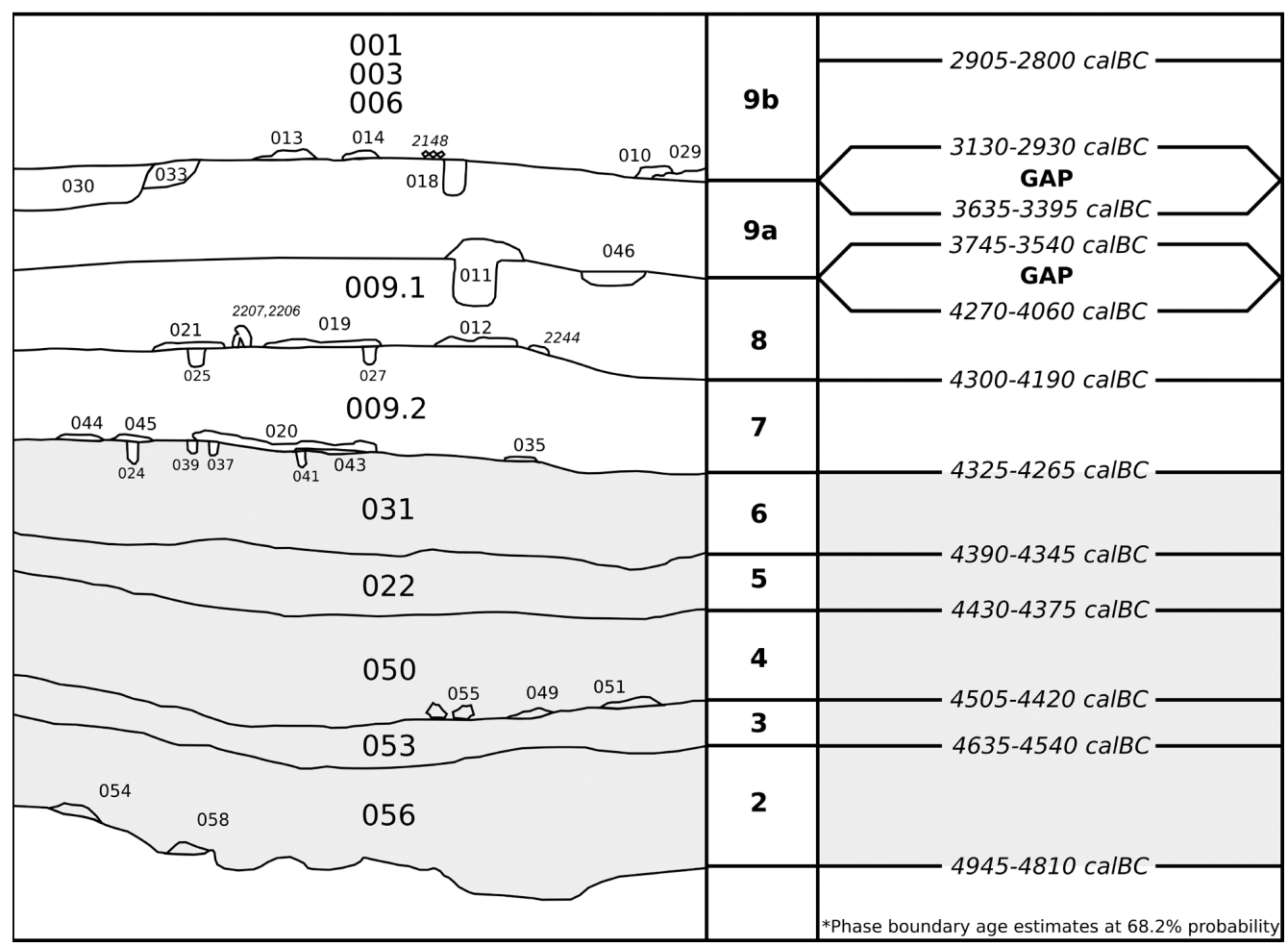

Fig. 2. Moverna vas stratigraphical sequence with Bayesian statistical modelling of radiocarbon dates.

(23MV, 29MV; App. 1; Tab. 1) or birch bark tar (24MV-28MV, 151MV, 152MV; App. 2; Tab. 1; Fig. 10). According to the results of chemical analyses, no freshwater reservoir effect is to be expected for these dates. Both the food crust and birch bark tar samples are considered as reliable samples with minimal inbuilt age (Hedges et al. 1992; Oinonen et al. 2010).

During the continuous occupation in the $5^{\text {th }}$ millennium, two related changes in 4325-4265 calBC (at $68.2 \%$ probability) have been observed. While the transition from Neolithic to Eneolithic vessel types and pottery fabrics was observed in the pottery assemblages (Tomaž 1997), the changes in settlement pattern relate to settlement fragmentation and settlement extension within the site-catchment areas, as well as in previously uninhabited areas (Budja 1995).

The pottery samples selected for lipid analysis were embedded in Neolithic settlement phases 2 to 6 ( $c$. 4945-4265 calBC) (Figs. 2, 4). The ceramic vessels of these settlement phases include various types of pot (Fig. 3.type 4, 5, 6, 8, 9), dishes with spouts (Fig. 3.type 1), pedestal dishes (Fig. 3.type 7), small pots (Fig. 3.type 3), bowls (Fig. 3.type 2), and ladles (Fig. 3.type 10). Most of the pottery was fired in an oxidising atmosphere and well made, with burnished surfaces and red or brown slips applied to the sur- face. The vessels were made with homogenous clay fabrics and abundant quartz grain inclusions, which in some samples can even be interpreted as added temper (Tomaž 1997; 1999; Žibrat Gašparič 2008).

\section{Mala Triglavca}

The Neolithic and Eneolithic sequence at the Mala Triglavca rock shelter consists of 23 occupational levels, ranging from $c .5600$ to $3500 \mathrm{calBC}$. The lipid analyses of the pottery assemblage, which is comprised mainly of various types of bowls, beakers, dishes and pots have been published (Šoberl et al. 2008; Budja et al. 2013) and will be used here mainly in relation to other sites in the discussion. The pottery samples were taken from Neolithic occupational levels and can be linked according to their morphology and technology to the Vlaška pottery group (Barfield 1972; Žibrat Gašparič 2004). The oldest pottery fragments appear as early as 56165525 calBC. For the lipid analysis, we sampled 65 vessels from contexts that range from 5480 to 4261 calBC (68.2\% probability). The results indicate an extensive mixing of ruminant and non-ruminant, and ruminant adipose and ruminant dairy fats in individual vessels. In some vessels, the presence of molluscs, crustaceans and freshwater fish was detected. Thirty per cent of the sampled pottery contained lipids characteristic of dairy fats, indicating 


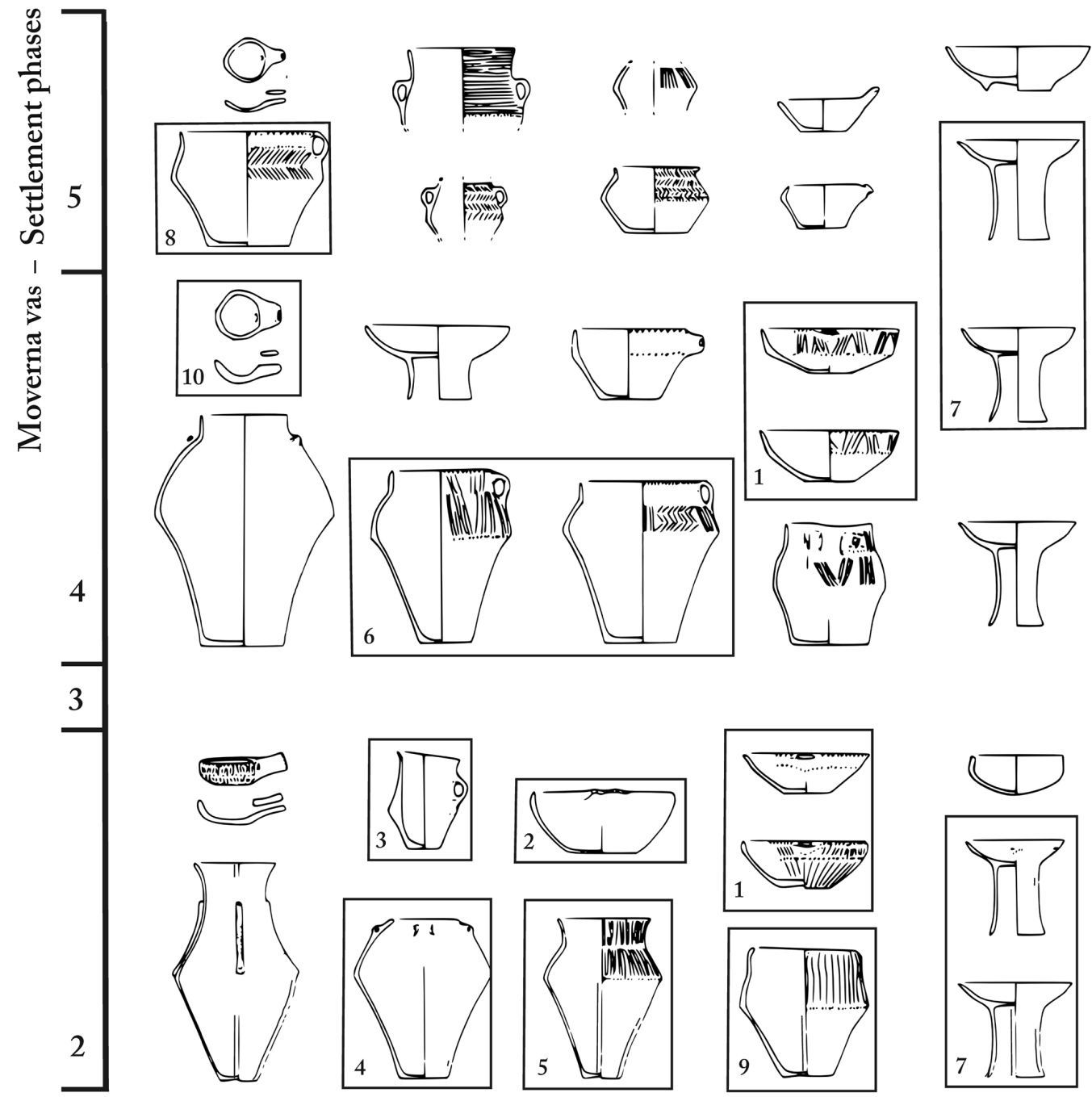

Fig. 3. Moverna vas pottery types represented within the different settlement phases. Types 1-10 wereanalysed for organic residues. See Appendix 1.

that the processing of dairy products in pottery vessels was quite extensive. The use of dairy products at Mala Triglavca is embedded in the time span between 5467-5227 calBC (for details see Budja et al. 2013).

\section{Ajdovska jama}

Excavations in Ajdovska jama proved that the cave was an eminent site at the end of the Neolithic period, with traces of temporary human activity until the High Middle Ages. Ajdovska jama is the funerary site with the oldest excavated burials in Slovenia, and a place where the remains of the dead were worshipped. The cave is also a natural karstic phenomenon, which might have had a symbolic meaning for prehistoric people.

The most typical grave goods of individual groups of burials that were excavated in the central hall and the left corridor included pottery (i.e. pot, dish, jug and ladle), jewellery (i.e. necklace or bracelet), and tools or weapons (i.e. axe, awl). The grave goods were found alongside the bodies of the deceased and prove that rituals were performed at the time of subsequent burials and visits to the cave. Food and meat were also placed beside the bodies as offerings. Analyses of plant and animal remains from the burials showed that cereals (e.g., wheat, barley and a type of bean) and the meat of domestic animals (i.e. ovicaprids, cattle) as well as wild animals (i.e. rabbit, wild boar, red deer, fox) were cooked (Horvat 1989). Additional information on diet came from the analyses of carbon $\left({ }^{13} \mathrm{C}\right)$ and nitrogen $(15 \mathrm{~N})$ isotopes in collagen obtained from human and animal bones. The results show that the people of this community consumed mostly meat and plant protein coming from $\mathrm{C}_{3}$ dietary source (Ogrinc, Budja 2005; Bonsall et al. 2007). Bayesian chronological modelling of ${ }^{14} \mathrm{C}$ dates provided by Clive Bonsall $e t$ al. (2007) shows that the burials belong to a relatively 

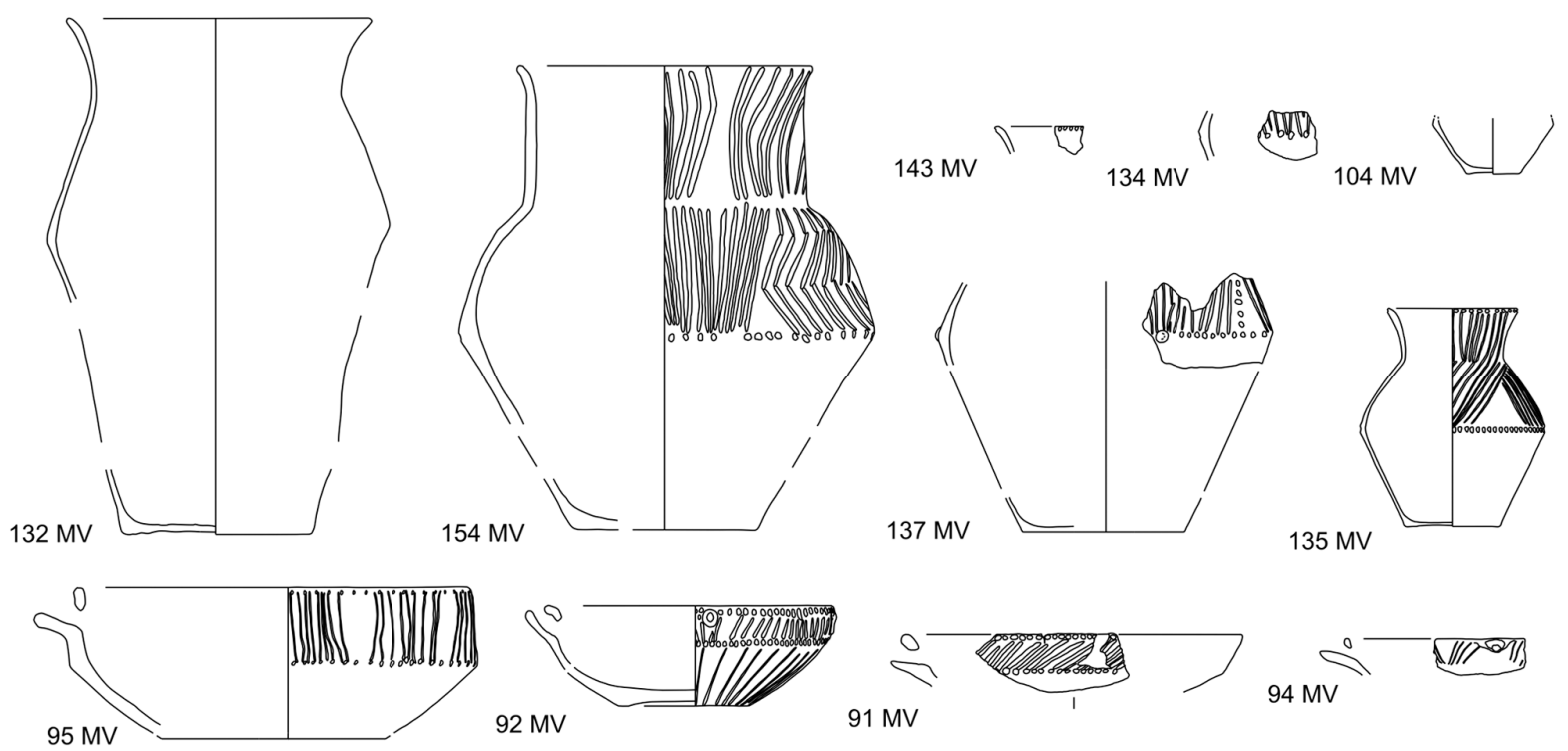
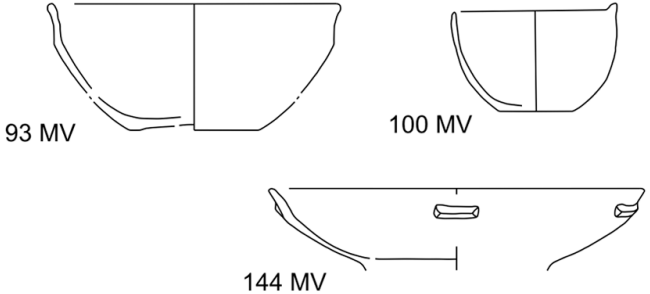
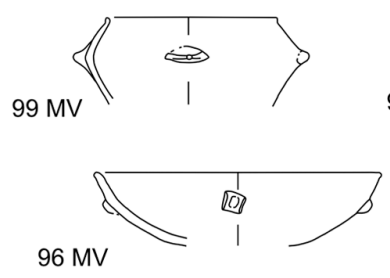

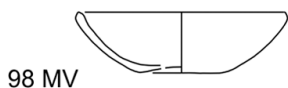

$10 \mathrm{~cm}$

Fig. 4. Vessels from Moverna vas that were analysed for organic residues.

short time interval of a few human generations from $4340-4290$ to $4295-4235$ calBC (at $68.2 \%$ probability).

A collection of 52 pottery samples was selected for lipid residue analysis, including various types of pots, dishes, dishes with spouts, pedestalled vessels, bowls and jugs (Fig. 5). Most of the vessels were fired in an oxidising atmosphere and were made with various fine-grained quartz fabrics (Horvat 1989; Osterc 1986).

\section{Organic residue analysis}

Cooking and processing organic commodities enables insoluble lipid residues to be absorbed into porous ceramic matrix and preserved for several thousand of years in the form of surface or/and absorbed residues. Cooking vessels have proved to be the most convenient for analysing organic residues due to their constant everyday use and exposure to high temperatures during cooking. However, non-culinary related vessel use can also absorb lipids when fatty commodities are stored: from the use of various sealants to reduce the permeability of the unglazed ceramic surface (resin, tar, pitch, milk and beeswax) and from the use of adhesives to repair broken ves- sels (Charters et al. 1993a; Regert, Rolando 2002; Regert 2004).

When determining the functionality of pottery, numerous archaeological methods can be employed, including written and pictorial evidence, the use of archaeological contexts, information obtained via ethnographical comparisons, pollen analysis of visible organic remains, use wear analysis and the analysis of preserved contents (Orton et al. 1993; Rice 1987; Tite 2008; Skibo, Feinman 1999). Prudence Rice (1987) divided the principle functions of pottery into three categories: (i) storing dry substances; (ii) carrying liquids; and (iii) heating the contents over fire. Direct evidence for storage vessels apart from their larger size is not readily available, cooking pots offer some additional indices, i.e. carbonised visible remains adhering to outer or inner pot surfaces and signs of sooting.

Chemistry offers interpretative tools for use in cases with a complete absence or selective preservation of organic and biological remains, such as osteological assemblages or plant remains; or for activities that are archaeologically difficult to trace, such as beekeeping. The primary focus of lipid research in the past 20 years has been to identify various biomar- 

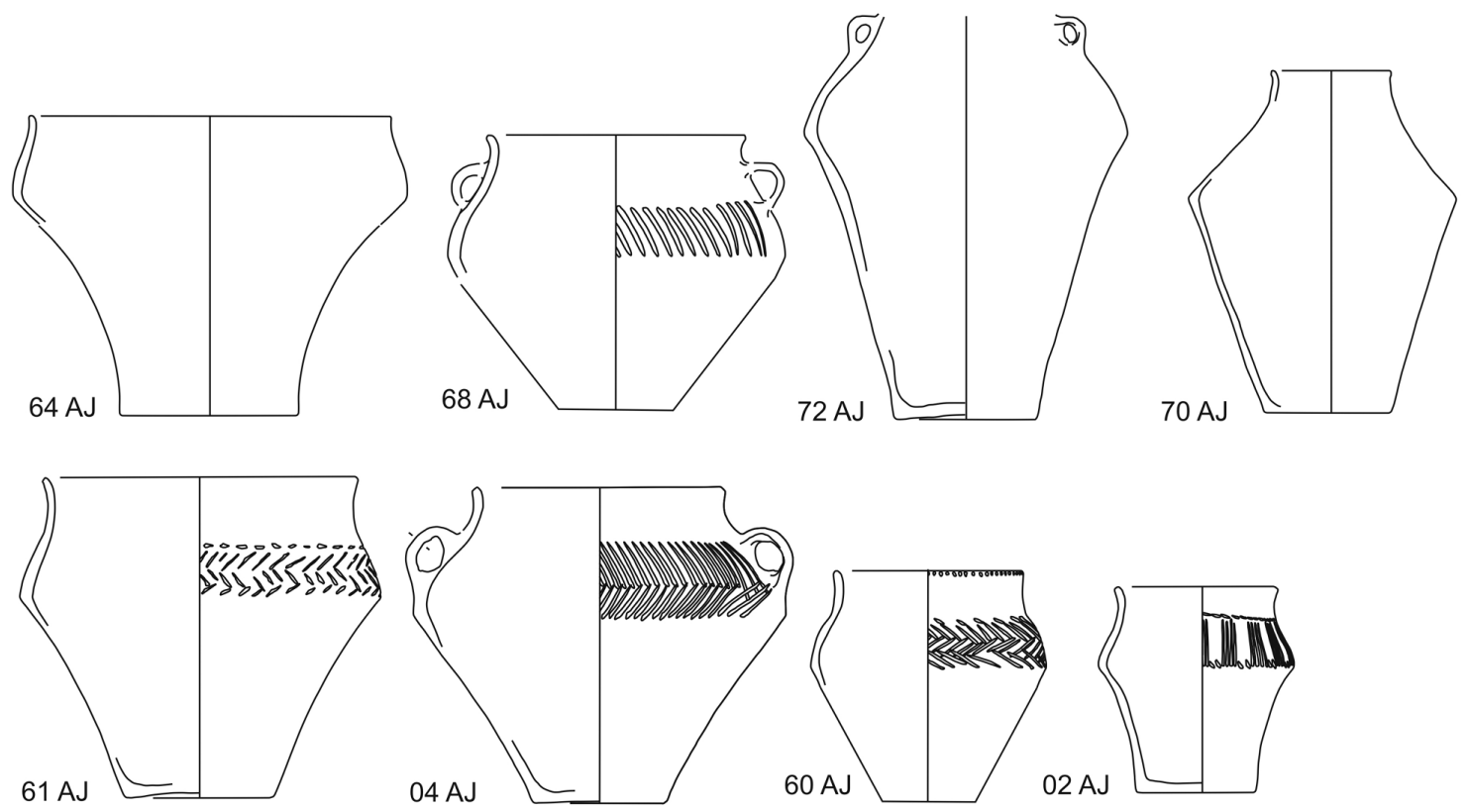

64 AJ
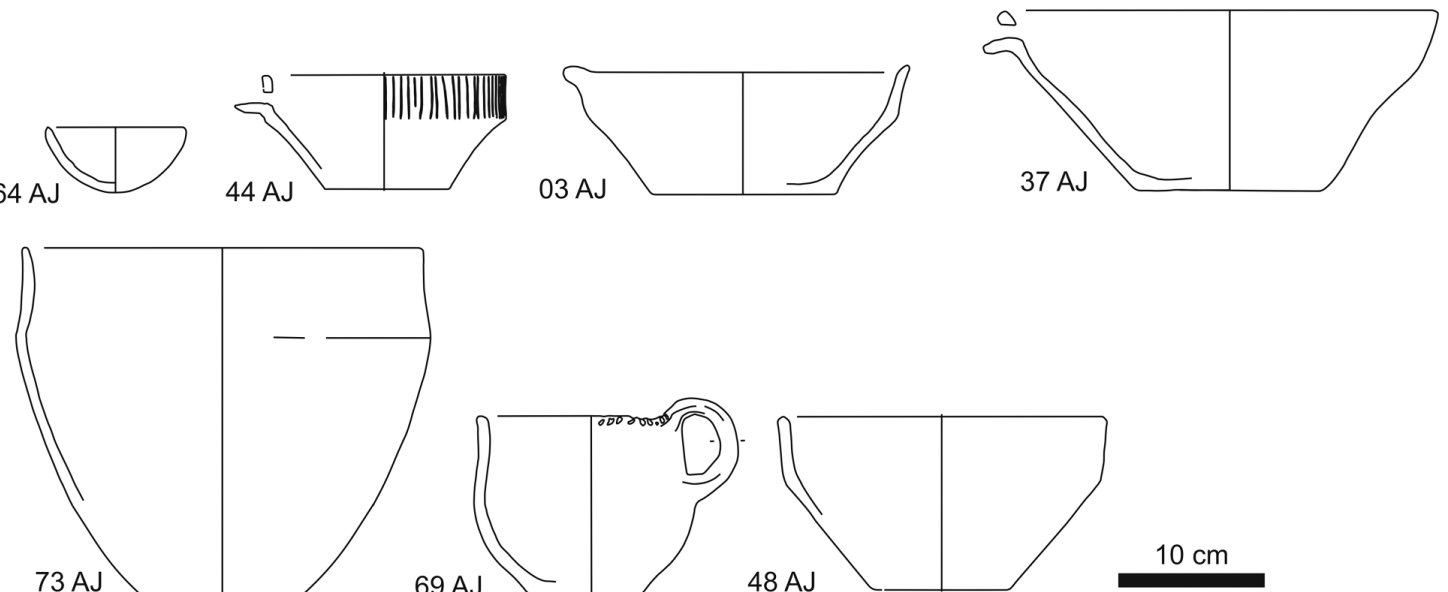

$69 \mathrm{AJ}$
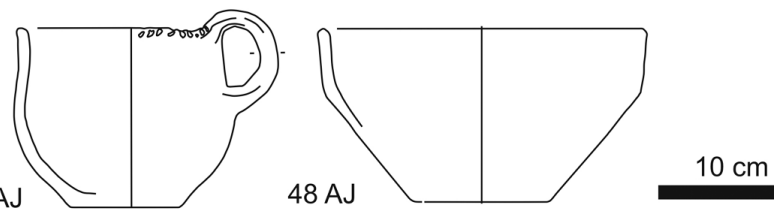

Fig. 5. Vessels from Ajdovska jama that were analysed for organic residues.

kers connected to specific domestic activities and ancient diets, and above all, identifying landmark transitions in ancient economies. These transitions include examples such as horse domestication (Outram et al. 2009), the earliest dairying practices in Europe, the Near East and Africa (Copley et al. 2005c; Craig et al. 2005; Evershed et al. 2008b; Dunne et al. 2012; Salque et al. 2013; Cramp et al. 2014); the chronologically and typologically diverse importance of pig exploitation (Mukherjee et al. 2007) and the evidence of geographical dependence on marine food sources (Copley et al. 2004b; Hansel et al. 2004; Evershed et al. 2008d; Craig et al. 2011; Cramp et al. 2014; Cramp, Evershed 2014).

The components of the lipid extracts of such residues can be identified and quantified by solvent extraction and a combination of analytical techniques that can achieve molecular level resolution, i.e. high temperature-gas chromatography (HTGC), GC/mass spectrometry (GC/MS; Evershed et al. 1990) and GCcombustion-isotope ratio MS (GC-C-IRMS; Evershed et al. 1994; 1999).

Furthermore, modern cooking experiments have helped to understand the accumulation of lipids caused by different cooking practices, vessel use and preservation. If we take into consideration that an average concentration of preserved lipids in archaeological pottery is around $100 \mu \mathrm{g} \mathrm{g}-1$, it is quite clear that only $1 \%$ or less of the original concentration survives post-depositional degradation (Evershed 2008). The initial lipid absorption also depends on the lipid content of processed food (animal $v$ s. plant products) and modes of food preparation or storage. Variations in long-term lipid preservation can also occur due to differences in fabric types. Animal fats are by far the most common class of residue identi- 
fied from archaeological pottery with compoundspecific stable carbon isotope analysis, allowing the identification of different animal fats, $e . g$., ruminant and non-ruminant adipose fats and dairy fats (Dudd, Evershed 1998), as well as the identification of the mixing of commodities (Charters et al. 1995; Evershed et al. 1999).

\section{Materials and methods}

Lipid analyses were performed with established protocols that are described in detail in earlier publications (Evershed et al. 1990; Charters et al. 1993b). The identification of individual compounds was based upon eluting order, a comparison of retention times to standards and by comparing the mass spectra with known fragmentation patters and NIST spectra library. In summary, after cleaning the potsherd surface, a $2 \mathrm{~g}$ fragment was ground to a fine powder and extracted using a mixture of chloroform and methanol $(2: 1 \mathrm{v} / \mathrm{v})$. An aliquot of the obtained total lipid extract (TLE) was trimethylsilylated and analysed directly by HTGC. Structure elucidation and molecular identification was achieved by GCMS and HTGC-MS analyses. Fatty acid methyl esters were prepared by saponification of a TLE aliquot with $\mathrm{BF}_{3} /$ methanol to enable compound-specific stable isotopic determination by GC-C-IRMS. The addition of an internal standard of known concentration (n-tetratriacontane, $1 \mathrm{mg} \mathrm{mL}^{-1}$ ) enabled the calculation of extracted lipid concentration. The discussion of recovery rates refers to the proportional number of pottery extracts with an appreciable preserved lipid concentration (>5 $\left.\mathrm{gg} \mathrm{g}^{-1}\right)$, which was determined as the lowest acceptable lipid concentration that can be reliably attributed to and interpreted as remnants of ancient food processing rather than modern contamination (Evershed et al. 1999; Evershed $2008 a$ ).

Visible surface residues were scraped from the ceramic surface with a clean scalpel, ground to a fine powder and extracted as described above; again an internal standard was added for lipid quantification.

A total of 179 potsherds and visible residues were selected for organic residue analysis: 52 samples from Ajdovska jama, 36 samples from Mala Triglavca and 91 samples from Moverna vas site. Potsherds were selected to represent different occupational phases and human activities at each site. Visible residues were sampled and analysed separately. To avoid duplication, where visible residues were present they were labelled with the number 1 , while the originating potsherd extract was labelled with the number 2 .

\section{Results}

Neolithic and Eneolithic pottery from Ajdovska jama, Mala Triglavca and Moverna vas showed a very good lipid preservation, with an overall $53.6 \%$ of potsherds analysed yielding an appreciable lipid concentration. The preservation of lipids in pottery is heavily influenced by the alterations that may occur during vessel use or due to post-burial conditions in the soil, as well as the use of ceramic vessels during their lifetime (Evershed et al. 1999; Evershed 2008a). These factors could explain the variations observed in average lipid concentrations and recovery rates between sites: the pottery assemblage from Mala Triglavca yielded the least TLE extracts, with appreciable lipid concentrations (30.6\%), followed by $48 \%$ of pottery from Ajdovska jama yielding lipids, while $65.9 \%$ of the analysed pottery from the Moverna vas site showed preserved organic residues. This trend is also repeated in observed median lipid concentrations from potsherd extracts as well as lipid concentration ranges. For a better demonstration of different concentration ranges, these are plotted as box-and-whiskers plots in Figure 5. Since, generally, only lipid concentrations higher than $5 \mu \mathrm{g} \mathrm{g}-1$ are considered as appreciable and can therefore be interpreted as archaeological, lipid concentrations below this threshold were ignored in the following comparisons (see Fig. 6 and Tab. 2).

The observed lipid concentration ranges are considerably narrower in the ceramic assemblages of Mala Triglavca and Ajdovska jama than those from Moverna vas. Since the latter site was a fully developed, permanent settlement, in contrast to the occasionally used rock shelter and burial cave, higher lipid concentrations could indicate frequent daily use of ceramic vessels resulting in an accumulation of residues.

The organic residues in the investigated pottery showed compound distributions typical of animal fats and plant material degraded to various degrees. The parent triacylgycerols (TAGs) present in fresh adipose fats and plant oils quickly degrade into their constituent fatty acids, with the palmitic $\left(\mathrm{C}_{16: 0}\right)$ and stearic $\left(\mathrm{C}_{18: 0}\right)$ fatty acids persisting in highest abundance, and with minor contributions from shorter chain saturated fatty acid components. Many vessels yielded only free fatty acids, indicating that complete hydrolysis of the precursor TAG components had taken place. Two gas chromatograms representing differing degrees of degradation and compounds most commonly identified in the Neoli- 
thic and Eneolithic residues analysed can be seen in Figure 7.

Fatty acids are usually present in the greatest abundance in archaeological lipid extracts with even rather than odd carbon number preference, dominated by palmitic $\left(\mathrm{C}_{16: 0}\right)$ and stearic $\left(\mathrm{C}_{18: 0}\right)$ fatty acids. While animal fats generally display a greater abundance of stearic acid, the plant derived lipids show a predominance of palmitic acid (Dudd 1999; Copley et al. 2005a; Romanus et al. 2007). The presence of odd carbon number free fatty acids (e.g., $\mathrm{C}_{15: 0}$, $\left.\mathrm{C}_{17: 0}, \mathrm{C}_{19: 0}\right)$ together with their iso- and anteiso-branched variations may indicate ruminant animal sources, as these compounds are biosynthesised by the bacteria living in the rumen (Mottram et al. 1999; Evershed et al. 2002).

Despite their predominance, the $\mathrm{C}_{16: 0}$ and $\mathrm{C}_{18: 0}$ fatty acids possess only limited biomarker potential. Broad groups of commodities can be alluded to only by investigating the $\mathrm{C}_{16: 0}$ vs. $\mathrm{C}_{18: 0}$ fatty acid ratio $(\mathrm{P} / \mathrm{S}$ ratio). Previous investigations of $\mathrm{P} / \mathrm{S}$ ratios in modern reference materials have provided some additional proxies; however, interpretations of these have to be applied with great caution and only in combination with other data, i.e. TAG distributions and $\delta^{13} \mathrm{C}$ values. Calculated $\mathrm{P} / \mathrm{S}$ ratios for pottery extracts from investigated sites are shown in Figure 8.

Previous studies have reported a $\mathrm{P} / \mathrm{S}$ ratio $<1.3$ as indicative of ruminant adipose fats; a $\mathrm{P} / \mathrm{S}$ ratio of approx. 2.2-2.9 and 4.9 indicative of dairy fats or non-ruminant adipose fats, while a $\mathrm{P} / \mathrm{S}$ ratio between 4.0 and 9.4 has been reported for commercial olive oils (Dudd 1999; Copley et al. 2005a; Romanus et al. 2007). P/S ratios calculated for TLEs of Slovenian pottery (Fig. 8) show a large proportion of 53 lipid extracts (68\%) falling below the 1.3 mark, indicative of ruminant adipose fat; 24 extracts $(31 \%)$ displaying the range 1.3-4.0, attributed to either rumi-

\begin{tabular}{|lccc|}
\hline Labels & $\begin{array}{c}\text { Ajdovska } \\
\text { jama }\end{array}$ & $\begin{array}{c}\text { Mala } \\
\text { Triglavca }\end{array}$ & $\begin{array}{c}\text { Moverna } \\
\text { vas }\end{array}$ \\
\hline Min & 5.02 & 5.53 & 5.25 \\
\hline Q1 & 8.26 & 10.81 & 18.03 \\
\hline Median & 32.45 & 21.93 & 118.18 \\
\hline Q3 & 79.25 & 65.95 & 503.45 \\
\hline Max & 557.13 & 173.35 & 3308.10 \\
\hline IQR & 70.99 & 55.14 & 485.42 \\
\hline $\begin{array}{l}\text { Upper } \\
\text { Outliers }\end{array}$ & 3 & 1 & 7 \\
\hline
\end{tabular}

Tab. 2. Details of absorbed lipid concentration ranges in analysed pottery.

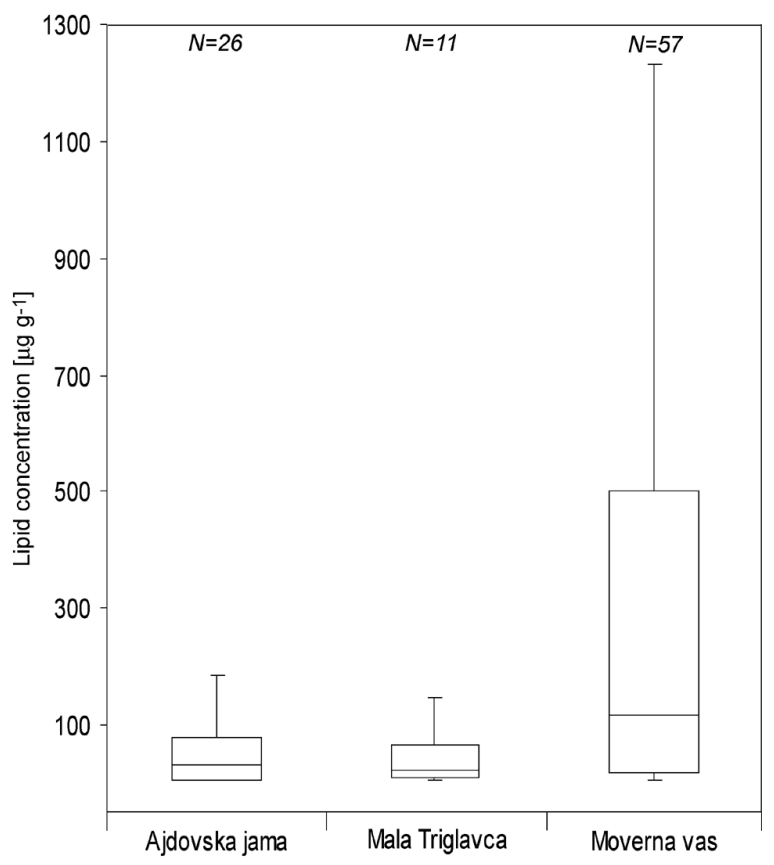

Fig. 6. Box-and-whisker plots showing the range of preserved appreciable lipid concentrations in pottery from Ajdovska jama, Mala Triglavca and Moverna vas. Only concentrations higher than $>5 \mu \mathrm{g} / \mathrm{g}^{-1}$ were used.

nant dairy or non-ruminant adipose fats; only $1 \mathrm{ex}-$ tract (1\%) displays a $\mathrm{P} / \mathrm{S}$ ratio higher than 4.0 , indicative of olive/plant oils.

The presence of ruminant-derived lipids has also been confirmed by observed distributions of odd carbon number saturated fatty acids with their branched iso- and anteiso- homologues $\left(\mathrm{C}_{15: 0}, \mathrm{C}_{15: 0 \mathrm{br}}\right.$, $\mathrm{C}_{17: 0}, \mathrm{C}_{17: 0 \mathrm{br}}$ ), biosynthesised by the bacteria living in the rumen (Dudd et al. 1998; Mottram et al. 1999; Vlaemnick et al. 2006). These branched fatty acid biomarkers were found in ten potsherd extracts: 08MT, 18MT, 75MT, 87MT, 23MV-2, 98MV, 134MV, $149 \mathrm{MV}, 153 \mathrm{MV}$ and $154 \mathrm{MV}$.

Apart from $\mathrm{C}_{16: 0}$ and $\mathrm{C}_{18: 0}$ fatty acids, a series of saturated long-chain fatty acids (LCFA) with a carbon number range between $\mathrm{C}_{20}$ and $\mathrm{C}_{30}$ has also been identified in fifteen potsherd extracts, representing $8 \%$ of the total assemblage: $03 \mathrm{AJ}, 37 \mathrm{AJ}, 69 \mathrm{AJ}, 70 \mathrm{AJ}$, 18MT, 29MV-2, 91MV, 99MV, 102MV, 111MV, 114MV, $121 \mathrm{MV}, 147 \mathrm{MV}, 149 \mathrm{MV}$ AND $154 \mathrm{MV}$. Such a series of LCFA has previously been associated with two potential sources, depending on the accompanying compounds. If found in combination with isoprenoid fatty acids such as phytanic or pristanic acid, 4,8,12-trimethyltridecanoic acid or $\omega$-(o-alkylphenyl)alkanoic acids, preserved lipids are most likely derived from marine organisms (Copley et al. 2004b; 


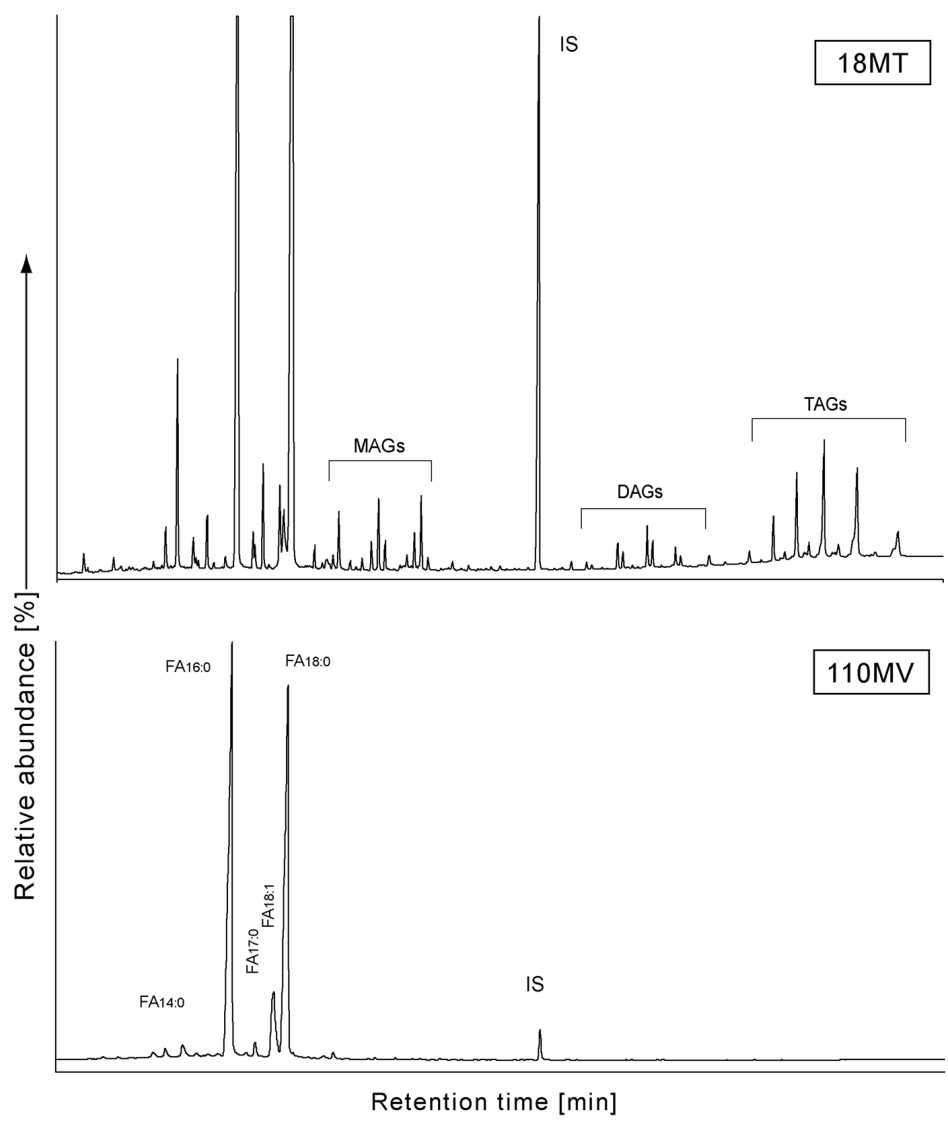

Fig. 7. Partial HTGC profile of the trimethylsilylated total lipid extract from potsherds 18MT (Mala Triglavca) and 110MV (Moverna vas) illustrating the contrasting distribution of compounds characteristic of partially and fully degraded animal fat. Key: FAX:Y are saturated free fatty acids of carbon length $x$ and degree of unsaturation $y$. IS is the added internal standard; MAGs are monoacylglycerols; DAGs are diacylglycerols; TAGs are triacylglycerols.

Hansel et al. 2004; Evershed et al. 2008c). LCFA extracted from Slovenian Neolithic and Eneolithic pottery, however, occur in high frequency together with long-chain n-alcohols of $\mathrm{C}_{22}$ to $\mathrm{C}_{32}$ even-carbon number series and analogous odd-carbon number n-alkane series of $\mathrm{C}_{23}$ to $\mathrm{C}_{33}$ chain length, which are more characteristic of degraded plant waxes (Tulloch 1976; Bianchi 1995).

Mid-chain ketones have been identified in six residues derived from five body sherds and one rim sherd (02AJ, 04AJ, 72AJ, 29MV-2, 91MV, and 133MV), most frequently displaying a narrow distribution with $\mathrm{C}_{29}, \mathrm{C}_{31}, \mathrm{C}_{33}$ and $\mathrm{C}_{35}$ homologues. These biomarker compounds are known to form by the condensation of fatty acids, involving decarboxylation and dehydration reactions occurring at high temperatures, typically in excess of $300^{\circ} \mathrm{C}$ (Evershed et al. 1995; Raven et al. 1997). The carbon chain length of ketones previously found in pottery extracts usu- ally ranges between $\mathrm{C}_{27}$ and $\mathrm{C}_{35}$, which reflects the length of the precursor fatty acids. These compounds have also been reported as components of the epicuticular leaf waxes of higher plants (Tulloch 1976; Kolattukudy et al. 1976). However, the presence of unsaturated ketones was identified in two lipid extracts (02AJ and 72AJ), suggesting the unsaturated fatty acid precursors common in plant oils. A similar series of ketones was also reported to be formed during vigorous pyrolysis at temperatures reaching $800^{\circ} \mathrm{C}$ (Raven et al. 1997).

\section{Waxes}

Beeswax recovered from archaeological contexts can undergo various degrees of alteration; however, four major groups of compounds provide biomarkers for its presence: (i) long-chain alcohols $\left(\mathrm{C}_{24}\right.$ to $\mathrm{C}_{32}$ ); (ii) odd-carbon number n-alkanes $\left(\mathrm{C}_{25}\right.$ to $\mathrm{C}_{33}$ ); (iii) a series of palmitic wax esters $\left(\mathrm{C}_{40}\right.$ to $\left.\mathrm{C}_{54}\right)$; and (iv) hydroxy palmitic wax esters $\left(\mathrm{C}_{42}\right.$ to $\left.\mathrm{C}_{54}\right)$. Similarly, plant waxes contain a mixture of compounds, including odd-carbon number n-alkanes $\left(\mathrm{C}_{21}\right.$ to $\left.\mathrm{C}_{37}\right)$, monoesters ranging in chain length from $\mathrm{C}_{32}$ to $\mathrm{C}_{64}$ and long-chain alcohols with a chain length range between $\mathrm{C}_{22}$ to $\mathrm{C}_{34}$ (Tulloch 1976; Heron et al. 1994; Mills, White 1994; Charters et al. 1995; Regert et al. 2001). A relatively large proportion of preserved lipid residues $(27 \%)$ showed traces of wax esters with chain lengths of $\mathrm{C}_{40}$ to $\mathrm{C}_{48}$, together with even-carbon number long chain alcohols $\left(\mathrm{C}_{22}-\mathrm{C}_{32}\right)$ and odd-carbon number straight chain alkanes $\left(\mathrm{C}_{23}-\mathrm{A}_{33}\right)$, which could either derive from diagenetically altered beeswax or degraded epicuticular plant waxes (Fig. 9).

Wax esters in these potsherd extracts were predominantly found together with free fatty acids and their acylglycerol moities, suggesting that the vessels were used to process both leafy plants and animal products; whether they were processed simultaneously or separately cannot be elucidated from this data. Interestingly, a beeswax residue was identified in cup extract 125MV without any contributions from animal fats or plant waxes. A further seven potsherd extracts from three vessels (25MV, 26MV and 28MV) contained birch-bark tar biomarkers in conjunction with wax esters, indicating mixing of commodities. 
Recent experimental work reported by Dana Millson (2011) and Merryn Dineley $(2000 ; 2011)$ has addressed the question of applying beeswax as a sealant, concluding that, although it is an effective waterproofing agent, it is not appropriate for use on cooking pots, causing the pot fabric to spall and flake off. Based on this, as honey would have been the earliest available natural sweetener, the beeswax residues identified in archaeological pottery could be interpreted as the remains of food processing that involved the addition of honey.

\section{Birch bark tar}

An unusual set of triterpenoid compounds was identified in 16 potsherd extracts from Moverna vas, representing seven vessels (24MV, 25MV, 26MV, 27MV, $28 \mathrm{MV}, 151 \mathrm{MV}$ and $152 \mathrm{MV}$ ) which had visible residues present on either the interior or exterior surface (Fig. 10). Visible residues are a common find on archaeological pottery, and routinely used for radiocarbon dating. It has been previously assumed/assessed that the exposed nature and structure of visible residues are usually not a good medium for preserving organic molecules (Evershed et al. 1992; Evershed 2008). It was possible to assess this variation, because visible residues were sampled and extracted separately. Lipid concentration values differ quite significantly, with values for visible residues averaging at $1537.04 \mu \mathrm{g} \mathrm{g}^{-1}$, while absorbed residues displayed an average lipid concentration of $25.5 \mu \mathrm{g} \mathrm{g}^{-1}$. The two sets of residues were also diffe-

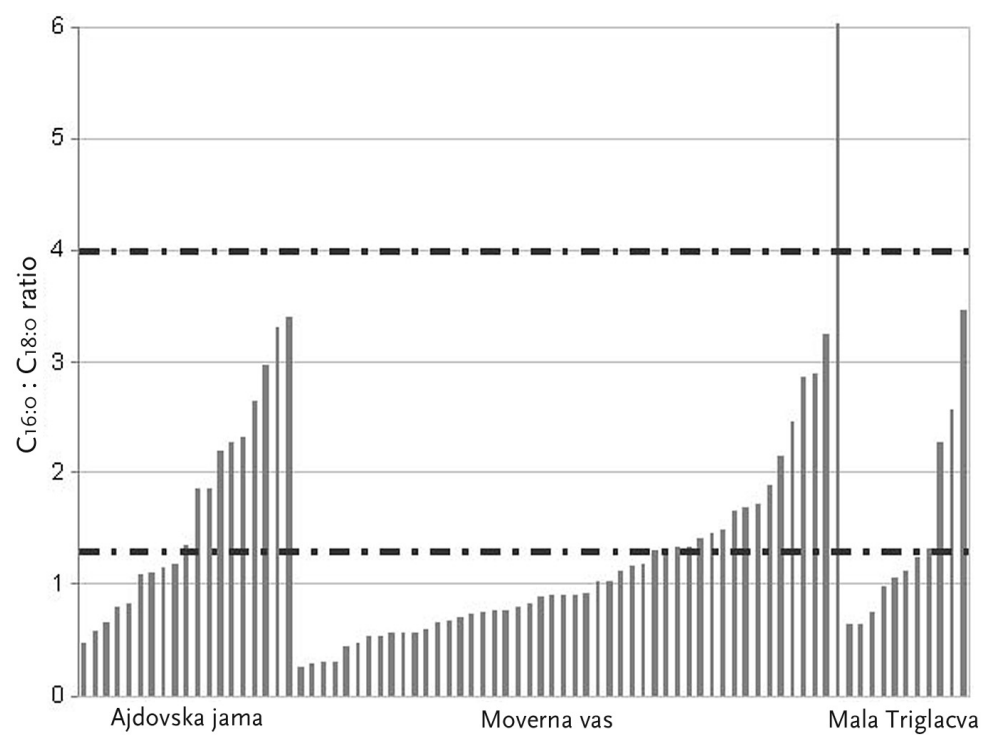

Fig. 8. Histograms representing the relative abundance ratios of palmitic $\left(C_{16: 0}\right)$ vs. stearic $\left(C_{18: 0}\right)$ fatty acid as detected in analysed potsherds. The dotted lines (set at 1.3 and 4) represent criteria as reported in the literature and used to separate ruminant adipose fats from non-ruminant, ruminant dairy fats and plant oils (Dudd 1999; Copley et al. 2005a; Romanus et al. 2007). rentiated by the biomarkers extracted: visible residues showed the presence of lupa-2,20(29)-dien-28-ol, allobetul-2-ene, lupenone, lupeol, betulone and betulin, which are characteristic of birch-bark tar. While betulin and lupeol are the predominant biomarkers present in birch-bark tar, other compounds are formed by degradation reactions, particularly the heating processes needed to produce the pitch. In particular, betulin is partly transformed into lupa2,20(29)-dien-28-ol by dehydration, whereas lupeol leads to the formation of a triterpenoid hydrocarbon identified as lupa-2,2-(29)-diene (Charters et al. 1993; Pollard, Heron 1996; Regert, Rolando 2002; Regert et al. 2003a: 2003b).

\section{Triacylglycerols}

Triacylglycerols, as the most abundant components of fresh animal fats and plant oils, can be useful indicators of lipid preservation and the extent of degradation. A comparison of TAG distributions with those of modern reference fats has shown that specific distributions can be linked to different lipid sources and enable the preliminary differentiation of their origins from the two major classes of domestic animals (ruminant and non-ruminant/porcine) and between ruminant dairy and adipose fats. Ruminant animals show a characteristic distribution of TAGs, with carbon numbers ranging from $\mathrm{C}_{44}$ to $\mathrm{C}_{54}$ with a maximum concentration at $\mathrm{C}_{52}$, whereas nonruminant animals display a slightly shorter distribution with carbon numbers between $\mathrm{C}_{46}$ and $\mathrm{C}_{54}$ with a low concentration at $\mathrm{C}_{46}$ and $\mathrm{C}_{54}$ and a maximum again at $\mathrm{C}_{52}$. Dairy fats show the widest TAG distribution, with carbon numbers ranging from $\mathrm{C}_{42}$ to $\mathrm{C}_{54}$, usually with two maxima at $\mathrm{C}_{50}$ and $\mathrm{C}_{52}$ (Evershed et al. 1997; Dudd, Evershed 1998; Mottram et al. 1999). Triacylglycerol remains (including samples with only trace amounts preserved) were identified in thirty pottery lipid extracts, representing $17 \%$ of the total assemblage investigated. Quantifiable TAG distributions as detected in lipid extracts from Slovenian potsherds are represented in Figure 11.

TAG distributions detected in potsherd extracts seem to be predominantly derived from ruminant adipose fats, with only 5 extracts (18MT, 79MT, 159MT, 96MV, 143MV) possibly deriving from ruminant dairy 


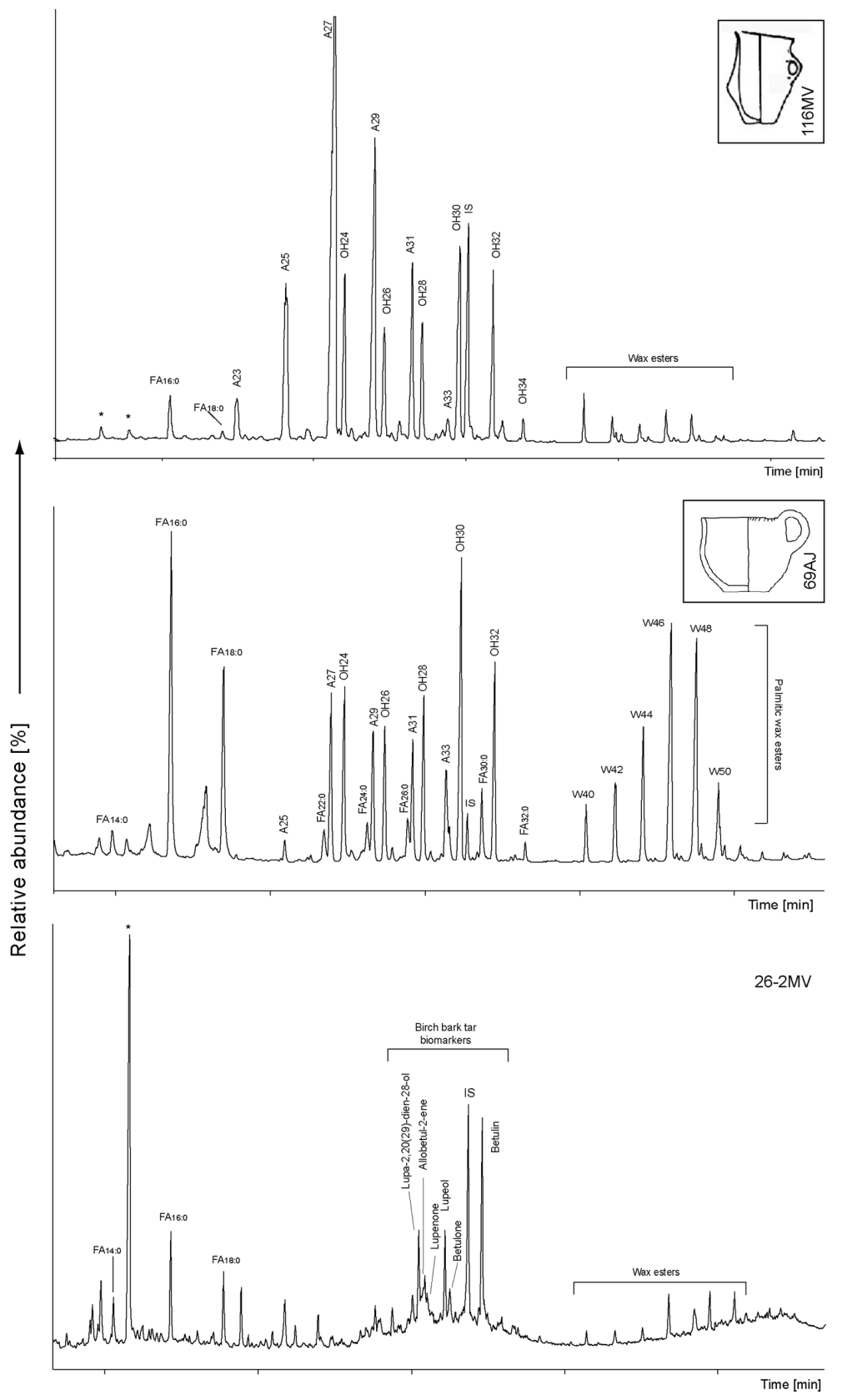

Fig. 9. Partial gas chromatograms of the trimethylsilylated TLEs from pottery showing the various biomarkers detected: $116 \mathrm{MV}$ epicuticular waxes residue; 69AJ a mixture of beeswax and plant residue; 26-2MV mixture of birch bark tar and plant residue. Key: FAx:y are fatty acids where $x$ is the carbon chain length and $y$ is the degree of unsaturation; OHx are long-chain alcohols of carbon chain length $x ;$ Ax are aliphatic alkanes of carbon chain length $x ;$ Wx are wax esters with carbon chain length $x ;$ IS is internal standard; * are plasticisers.

residues and with no TAG distribution indicating the presence of porcine fats. However, laboratory experiments have shown that TAG distributions can be skewed by degradation occurring during use or postdeposition, causing the wide TAG distribution characteristic of fresh ruminant dairy fat to become considerably narrowed due to the preferential degrada- tion of compounds with lower carbon numbers, and thus come to resemble the narrower distribution seen in ruminant adipose fat TAGs distribution (Dudd, Evershed 1998; Aillaud 2001). Conclusions from TAG distributions have to be drawn with caution and serve only as preliminary results, complemented with compound-specific carbon isotope ratio measurements.

\section{Compound-specific stable carbon isotope analysis}

Compound-specific stable carbon isotope values $\left(\delta^{13} \mathrm{C}\right)$ were obtained for the palmitic $\left(\mathrm{C}_{16: 0}\right)$ and stearic $\left(\mathrm{C}_{18: 0}\right)$ fatty acid methyl ester derivatives (FAMEs) from 52 Neolithic and Eneolithic potsherd residues with sufficient lipid concentrations. In order to elucidate the origin of preserved lipids accurately, archaeological $\delta^{13} \mathrm{C}$ values were compared with modern reference fats from animals reared on isotopically similar diets to those of animals in prehistory. To eliminate any isotopic variations occurring in animals through differences in dietary intake or environmental factors, the difference between $\delta 13 \mathrm{C}_{18: 0}$ $\delta 13 \mathrm{C}_{16: 0}$ values $\left({ }^{13} \mathrm{C}\right)$ is plotted in Figure $12 . \Delta^{13} \mathrm{C}$ values ranging from -3.3 to $-6.3 \%$ indicate ruminant dairy fats; values from 1.0 to $2.8 \%$ o represent ruminant adipose fats, while values from -0.7 to $+1.9 \%$ o indicate porcine adipose fats ( $\mathrm{Dudd}$, Evershed 1998; Evershed et al. 2008; Craig et al. 2011; Dunne et al. 2012; Salque et al. 2013).

Distributions of stable carbon isotopic values of lipids preserved in Neolithic and Eneolithic pottery show differences between individual archaeological sites: the residues recovered from Ajdovska jama pottery were predominantly of ruminant adipose (5 extracts) and ruminant dairy origin ( 4 extracts), while those from the Moverna vas pottery assemblage were mainly of ruminant adipose origin (17 extracts). The ubiquitous presence of dairy lipid residues in vessels from Mala Triglavca has already been reported, with $63 \%$ and 
$17 \%$ of vessels being used to process or store dairy products, respectively (Šoberl et al. 2008; Budja et al. 2013). The lowest occurrences were of porcine derived lipids, being found on only one potsherd from Ajdovska jama and three potsherds from Moverna vas. The mixing of various commodities throughout the life of vessels can also be seen by $\delta{ }^{13} \mathrm{C}$ values plotting close to, or between, the ranges of modern reference fats. It has been assumed that the pottery extracts with minor concentrations of leaf waxes or beeswax components present still reflect the isotopic signature of predominant fatty acids present in the residues.

\section{Discussion}

\section{Pottery use in different contexts}

Pottery has been traditionally regarded as a passive bearer of culture; however, with the rise of contextual archaeology, pottery has come to be seen more as an active factor, brought about by human agency and used in the construction of social identity (Boast 2002; Gibson 2002). Ceramic vessels could be used for many primary functions, such as the preparation, storage and cooking of food, brewing, tanning, dairying, dyeing, fulling, textile washing, transporting and salt preparation.

Whatever pottery was used for, it was an important artefact, as demonstrated by its appearance at domestic sites, as well as within ritually structured deposits. Pottery deposited in funerary settings could consist of previously used vessels or one made deliberately for that purpose.

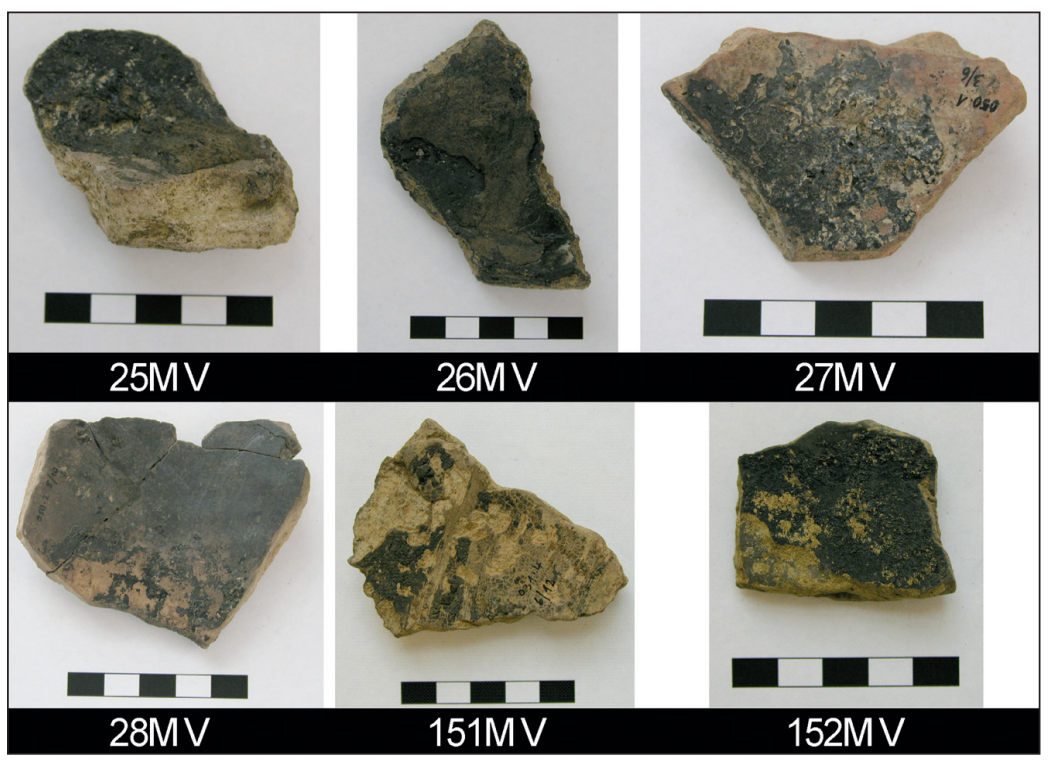

Fig. 10. Potsherds from Moverna vas with visible residues, remnants of birch bark tar application or production.
Although pottery is very robust and able to survive, it is also very sensitive and responsive to cultural, social, economic and ideological changes. These can be mirrored in a variety of ways: decoration, design, typology, modes of use and deposition.

\section{Ajdovska jama}

The ceramic vessels recovered from the Ajdovska jama site formed part of Neolithic burial rituals, acting as grave goods or simply containers for food offerings. Lipid preservation in ceramic vessels was good, with almost half of the potsherds (48\%) yielding an appreciable amount of organic residue. The variety of animal remains deposited with the burials is well reflected in preserved fatty acid composition and isotopic signatures, indicating that ceramic vessels predominantly contained ruminant animal products (meat and dairy), while only one vessel showed the presence of porcine fat. The presence of mid-chain ketones in three pots $(02 \mathrm{AJ}, 04 \mathrm{AJ}, 72 \mathrm{AJ})$, formed by the condensation of precursor fatty acids at high temperatures in the presence of clay, suggests these vessels were used as cooking pots (Fig. 5). The extraction of uncommon unsaturated midchain homologues in $02 \mathrm{AJ}$ pot could be the result of processing plant material which contains high concentrations of unsaturated fatty acids. This was also suggested by the extracted organic residues, which in combination with the excavated plant remains (burnt, scattered cereal grains and pulses), show a high contribution of a plant-based diet, with approx. $25 \%$ of vessels containing some plant biomarkers. A mixed diet of plants and animals was also attested in bulk stable isotopic determinations $\left(\delta^{13} \mathrm{C}\right.$ and $\left.\delta^{15} \mathrm{~N}\right)$ of collagen extracted from osteological remains recovered from the burials (Ogrinc, Budja 2005; Bonsall et al. 2007). However, enriched $\delta^{13} \mathrm{C}$ values of palmitic acid extracted from lipid residues in ceramics (Fig. 12) could indicate a $\mathrm{C}_{4}$ or marine component in the animal-based diet, as they are strongly diet-dependent (Copley et al. 2003). Since a marine dietary contribution seems unlikely in the case of Ajdovska jama, enriched $\delta{ }^{13} \mathrm{C}_{16: 0}$ values could have been introduced via animals eating plants from a waterlogged environment (Salque et al. 2012). This observed difference between Ajdovska jama, Mala Triglavca and Moverna vas isotopic values 


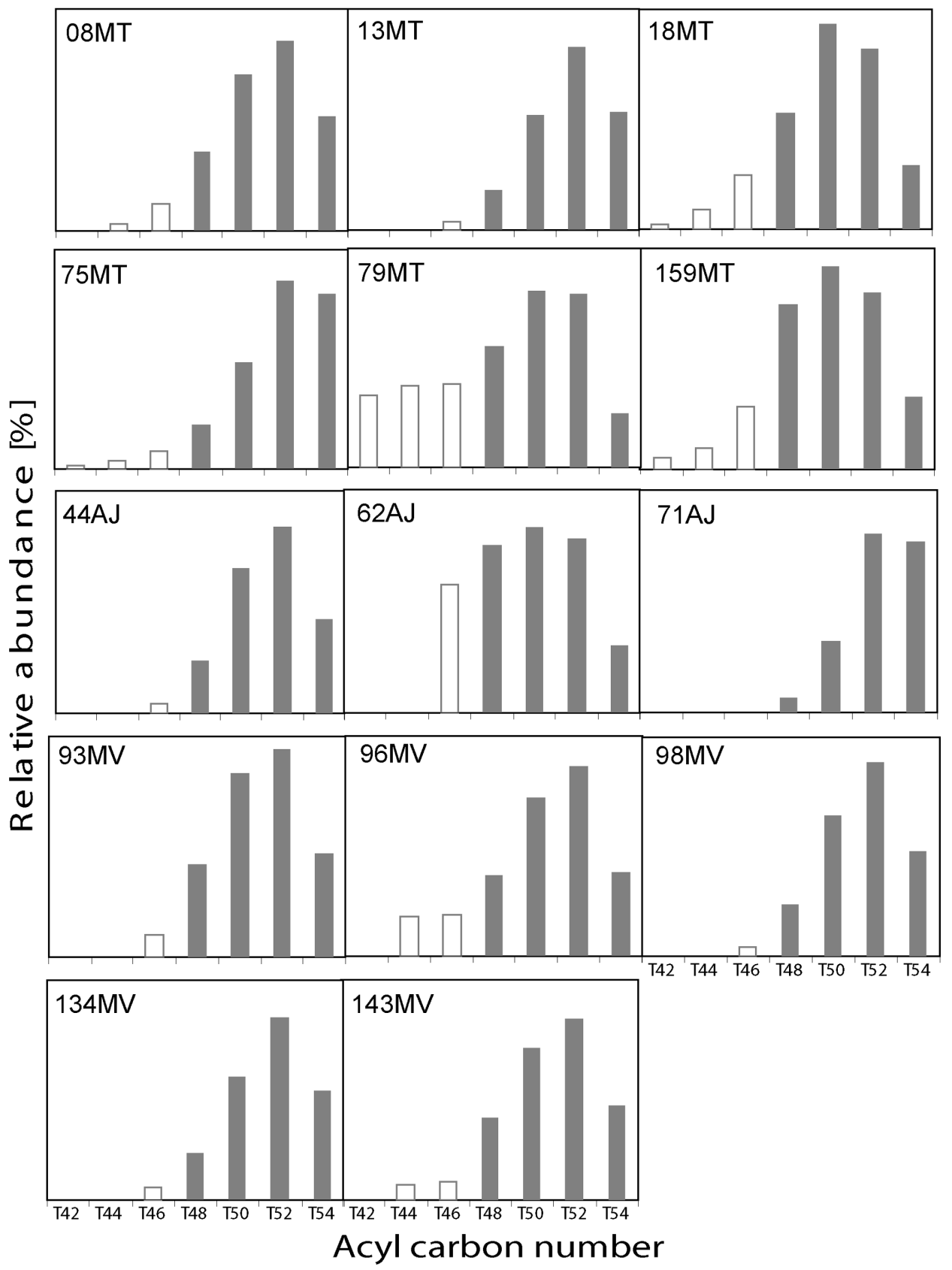

Fig. 11. Histograms showing triacylglycerol (TAG) distributions detected in pottery lipid extracts from Ajdovska jama, Mala Triglavca and Moverna vas. TX denotes the number of acyl carbon atoms in individual TAGs, grey bars represent TAGs identified in modern adipose and dairy fats while those in white are usually found only in dairy fats.

was also confirmed statistically with a two-tailed student's T-test which returned probability values of 0.003 and 0.016 .

\section{Mala Triglavca}

Rock-shelters such as Mala Triglavca were used as gathering places for Mesolithic populations, and some could have been subsequently transformed into shelters and pens for domestic animals during the Neolithic. An analysis of herd structure and mortality on faunal remains (sex and age of animals) can be used to produce 'kill-off curves' in order to distinguish between meat or dairy animal exploitation (Payne 1973). Kill-off curves from Neolithic sites in the Northern Adriatic region have been interpreted in two ways: while Preston Miracle, Stašo Forenbaher and Laura Pugsley believe herds of domestic animals were kept predominantly for dairying, Dimitrij Mlekuž suggests simple, non-optimised animal husbandry (Miracle, Forenbaher 2005; Miracle, Pugsley, 2006; Mlekuž 2005; 2006; Bonsall et al. 2013; Rowley-Conwy et al. 2013). 


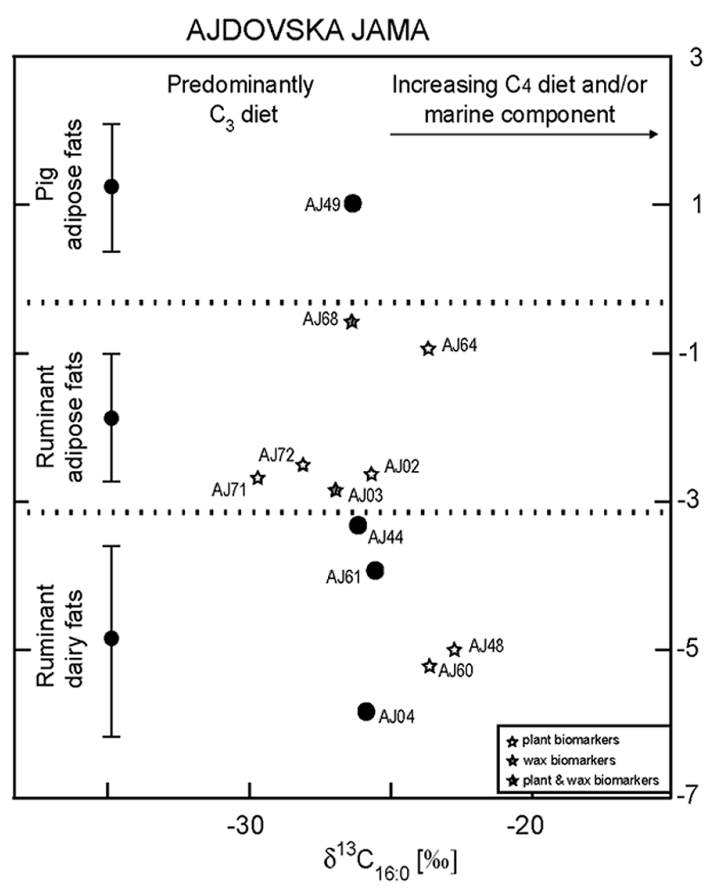

Fig. 12. Scatter plots showing $\Delta^{13} \mathrm{C}$ values $\left(\delta^{13} C_{18: 0}-\delta^{13} C_{16: 0}\right)$ and $\delta^{13} C$ values of $C_{16: 0}$ fatty acids extracted from Neolithic and Eneolithic pottery from sites Ajdovska jama, Mala Triglavca and Moverna vas. The ranges for the modern reference fats obtained from Europe, Africa, Kazakhstan and the Near East are plotted to the left of the diagram with mean \pm 1 s.d. (Salque et al. 2013). The $813 \mathrm{C}$ values obtained for modern reference animal fats have been adjusted for the post-Industrial Revolution effects of fossil fuel burning, by the addition of 1.2\%o.

The findings of absorbed organic residues from Mala Triglavca rock-shelter pottery have been discussed elsewhere ( Soberl et al. 2008) together with a more recent analysis of another pottery assemblage from the same site (Budja et al. 2013). Both studies show lipid biomarkers of a mixed animal and plant economic model. Domesticates were simultaneously exploited for meat and milk. The question of the contribution of game to the diet of the Neolithic occupants of this rock-shelter, as attested in zoological remains, has yet to be addressed and investigated. Ceramic vessels displayed the lowest concentration range of preserved lipids, as well as an absence of mid-chain ketones, suggesting perhaps less intense food processing (no heat involved) or a faster turnover in pottery use. While porcine fats were completely absent, the $\delta 13 \mathrm{C}$ values of most abundant fatty acids $\left(\mathrm{C}_{16: 0}\right.$ and $\left.\mathrm{C}_{18: 0}\right)$ fall within a range expected for ruminant dairy (75\%) and ruminant adipose fats (25\%; Fig. 12). Traces of odd-carbon num-
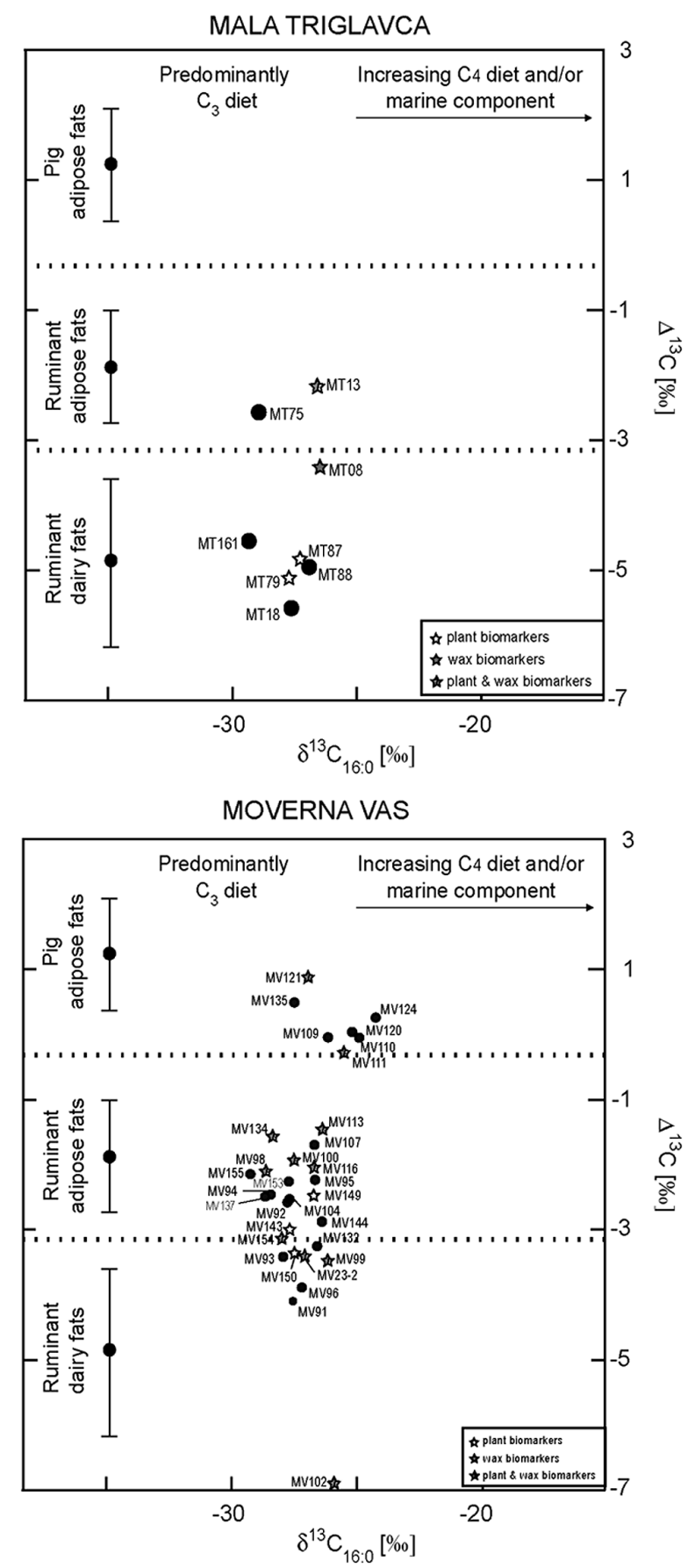

ber aliphatic alkanes, even carbon number longchain alcohols and wax esters were detected in three potsherds (08MT, 13MT, 79MT), indicating a degree of mixed commodities (meat as well as vegetables) being processed within these vessels.

\section{Moverna vas}

The Neo-Eneolithic settlement of Moverna vas had fully developed animal husbandry with agriculture, as well as diverse pottery production. The complexity of this settlement was mirrored perfectly in the lipid biomarkers extracted from the ceramic vessels. The 99 potsherds analysed covered a diverse vessel 
typology, from large cooking and storage pots to small 'drinking' cups and highly specialised pedestal dishes. Intensive use of ceramic vessels in food preparation and storage is reflected in the highest lipid concentration range (Fig. 6) and the presence of midchain ketones identified in three potsherds (29MV2, 91MV, 133MV) (Fig. 4). Extensive mixing of commodities (meat and plants) is apparent from extracted lipid biomarkers, in which not only free fatty acids were identified together with their parent acylglycerol moieties, but also a suite of other compounds, i.e. aliphatic alkanes, long-chain fatty acids, long-chain alcohols, triterpenoids and wax esters. In the absence of faunal remains, compound specific stable isotope analysis of palmitic and stearic fatty acid enabled us to approximately reconstruct animal husbandry practices. While $\delta^{13} \mathrm{C}$ values for $\mathrm{C}_{16: 0}$ and $\mathrm{C}_{18: 0}$ extracted from ceramic vessels found at Ajdovska jama and Mala Triglavca sites showed the ubiquitous presence of ruminant meat and dairy products, the potsherds from Moverna vas settlement contained predominantly ruminant and porcine adipose lipids (Fig. 12). Only seven potsherds revealed the presence of milk residues (23$2 \mathrm{MV}, 91 \mathrm{MV}, 93 \mathrm{MV}, 96 \mathrm{MV}, 99 \mathrm{MV}, 102 \mathrm{MV}, 150 \mathrm{MV})$ (Fig. 4). An elusive association of porcine products with prehistoric pottery has been observed in the past, especially in British Neolithic pottery (Mukherjee et al. 2007) as well as two recently investigated Slovenian Neolithic pottery assemblages from Maharski prekop and Resnikov prekop. While porcine derived lipids were detected in extracted residues at Resnikov prekop, the same class of foodstuff was completely absent from Maharski prekop (Ogrinc et al. 2012; Mlekuž et al. 2012; 2013). The discrepancy in preserved porcine lipids and faunal statistics may be the result of alternative ways of preparing porcine meat that did not necessarily involve pottery, but perhaps spit-roasting, as suggested by Umberto Albarella and Dale Serjeantson (2002).

\section{Pottery use within typology}

The ubiquity of pottery finds in all archaeological sites shows indirectly that this was a commodity produced en masse and used daily, not simply made for display or burials. From the perspective of pottery typology, it is only assumed which vessels were used for storing and/or cooking food.

Investigations of British Neolithic and Bronze Age pottery revealed correlations between specific commodity groups and three main differential criteria: (a) pottery size/rim diameter; (b) pottery typology, and (c) various household activities (Copley et al.
$2005 c ; 2005 d$ ). Similarly, biomarkers for a specific commodity, dairy products in this case, were detected in Neolithic ceramic sieves in Europe, which were in turn interpreted as cheese strainers (Salque et al. 2013). Lipid residue analyses of pottery from Ajdovska jama, Mala Triglavca and Moverna vas have shown some correlations between lipid concentrations and pottery typology (Figs. 4, 5 and 13), while only two correlations between specific commodities and vessel types have been observed. Mid-chain ketones, which are used as biomarkers for exposure to high temperature (cooking), were observed in only three vessel types, all characterised either by larger volumes or openness of rims: pots, bowls and dishes. Pots and pedestal dishes were also unique ceramic types associated with birch-bark tar biomarkers.

Rice (1987) divided the principle functions of pottery into three categories: (i) storing dry substances; (ii) carrying liquids; and (iii) heating contents over fire. The investigation of potsherd samples taken from different parts along the profile of the same ceramic vessel compared to laboratory cooking simulation experiments has shown correlations between concentrations of absorbed lipids, their spatial distribution and different modes of pottery use.

The hydrophobic nature of lipids and their lower density results in the highest lipid concentrations to be absorbed near the top of the vessel, where the original water line would have been (Charters et al. 1997). Other lipid distributions observed in the bases of vessels are thought to indicate an analogous preparation of food, namely roasting, or the application of surface sealing treatments (Charters et al. 1993b; 1997).

The average lipid concentration profiles in Figure 13 were divided into rim, body and base sherds to assess potential variations in distinguishing pottery use. Investigated pottery from Ajdovska jama, Mala Triglavca and Moverna vas shows distinct differences in vessel use: while average lipid concentration in cups peaks in the upper parts of the vessels, suggesting preferential absorption of immobilised lipids, an opposite concentration distribution was observed for pots and jugs, where the highest concentration in the lower vessel parts could indicate 'dry' cooking.

Average lipid concentration poses an interesting question as well; accepting that lipid accumulation correlates with the longevity of vessel's use, it is clear from Figure 13 that pedestal dishes, small cups and 

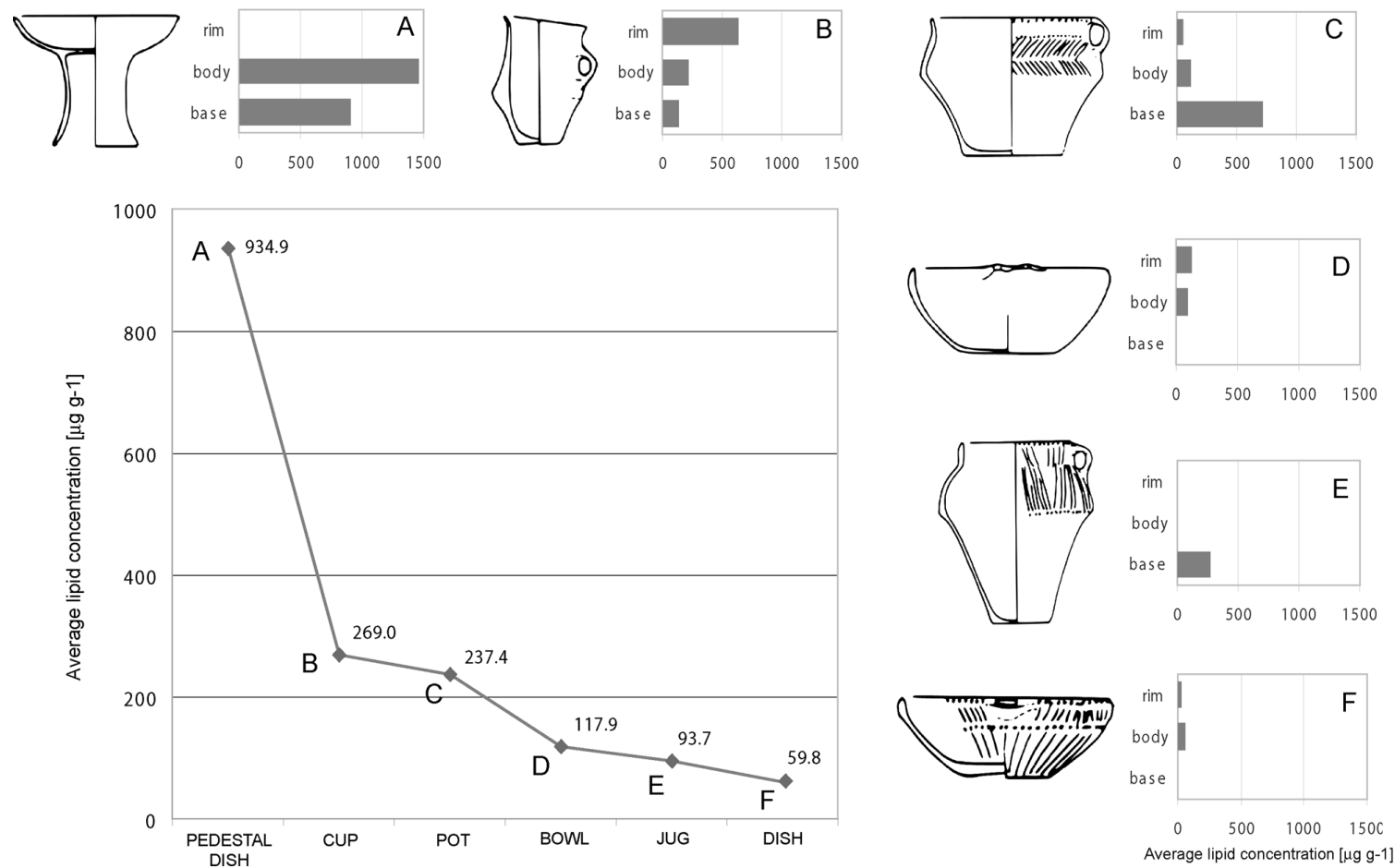

Fig. 13. Diagrams showing the mean concentration of extracted lipids according to ceramic typology and potsherd location.

pots with the highest preserved lipid concentrations (935, 269 and $237 \mu \mathrm{g} \mathrm{g} \mathrm{g}^{-1}$, namely) were probably used regularly to process or store fatty foodstuffs over an extended period. On the other hand, bowls, jugs and dishes were perhaps used only as storage vessels for less fatty commodities, or were perhaps dedicated serving vessels. An estimate of the longevity of cooking pots in regular use ranges between three months, one year and even longer periods of two to ten years (Foster 1960; David 1972; DeBoer 1974; Rice 1987; Longacre 1991).

\section{Birch-bark tar - a multi-purpose widespread prehistoric commodity}

Similar to beeswax, resins have also been shown to have had various potential applications in prehistory: as adhesives (Charters et al. 1993a; Regert et al. 2003b), for medicinal use (Lucquin et al. 2006; Evans, Heron 1993), as a waterproofing agent (Evershed et al. 1985; Robinson et al. 1987; Romanus et al. 2009) in pitch and tar production (Eerkens et al. 2002) or perhaps in wine production (McGovern et al. 2009). The presence of birch-bark tar has been widely reported from various prehistoric archaeological contexts, where it was mainly used as hafting adhesive on arrowheads or as a material used to repair broken ceramic vessels as early as the Neolithic (Pollard, Heron 1996; Regert, Rolando 2002; Regert et al. 2003b; Regert 2004; Lucquin et al. 2006). Birch-bark tar is sometimes also found as free lumps in sediment or in the form of visible residues on the exterior or interior surfaces of ceramic vessels (Charters et al. 1993; Bosquet et al. 2001; Urem-Kotsou et al. 2002; Regert et al. 2003; Lucquin et al. 2006). Birch-bark tar was only identified as a visible organic residue on pottery from Moverna vas, where it was linked specifically to pedestal dishes and pots. Pedestal dishes have been previously reported together with this natural product from Neolithic funerary contexts in Brittany (Lucquin et al. 2006), where the authors interpreted these vessels as incense burners' or portable hearths. As the smell of burning tar is quite unpleasant, it has been suggested that it might have been used to mask strong odours, such as decomposing bodies in funerary contexts (ibid.). This theory could explain the find of a small, black, amorphous lump of tar within the burial sediments in Ajdovska jama, where burial rituals were similar to those described above (Šercelj, Culiberg 1984). The presence of this natural substance has also been reported from the Urnfield culture cemetery at the Slovenian Academy of Sciences and Arts in Ljubljana (Puš 1976; Hadži, Cvek 1976; Hadži, Orel 1978) and the Neolithic pile dwelling site at Maharski prekop (Hadži, Orel 1978). The availability of birch trees in prehistory has also been confirmed by palinological analysis of contemporary regional sediments, where a decline has been recorded after 6400 cal BP with the increase of 'anthropogenic indicators' (Andrič 2007). 


\section{Conclusions}

The organic residue analysis of the Neolithic and Eneolithic pottery from Ajdovska jama, Mala Triglavca and Moverna vas showed very good lipid preservation, enabling us to reconstruct the past pottery use and address potential contextual differences. The choice of three sites with very diverse archaeological contexts has proven to be justified, as the vessels retained varying lipid concentrations, probably depending on their originating contexts.

Pottery from Mala Triglavca rock shelter yielded the lowest lipid recovery $(30.6 \%)$ as well as the lowest lipid concentration range, which together with the absence of mid-chain ketones identified might suggest less intense food processing, without heating, or a faster turnover in pottery use. Lipid biomarkers confirm the archaeozoological data, i.e. the presence of domesticated ovicaprids, which were exploited for both meat and dairy products, occasionally mixed with plant-based foods as indicated by biomarkers.

The Ajdovska jama pottery that played a part in prehistoric funerary rituals proved to retain $48 \%$ of vessels with identifiable lipid residues. Identified biomarkers reflect the animal remains that were deposited with the deceased, suggesting a mixed plant and animal based diet. The compound specific stable isotopic analysis of primary fatty acids suggests that the lipids derive from ruminant animals (meat and dairy) and one porcine fat residue, most likely a remnant of wild boar. A high occurrence of plant biomarkers ( $25 \%$ of the pottery assemblage) in conjunction with recovered palaeobotanical remains suggests that a large proportion of the cave visitors' diet or food offerings were plant based.

The highest lipid recovery rate (65.9\%) as well as the broadest lipid concentration range of Moverna vas settlement pottery can be interpreted as an indication that prehistoric ceramic vessels were used frequently to process or store foodstuff of animal as well as vegetable origin. The complexity of biomarkers in ceramic vessels mirrors perfectly the complexity of a fully developed Neolithic and Eneolithic settlement economy. Ceramic vessels were used to process animal products (ruminant and porcine adipose fats) and plant-based foodstuffs, as well as more rare commodities such as beeswax (perhaps indicating the presence of honey) and birch-bark tar. Pots and pedestal dishes were unique ceramic types associated with birch-bark tar biomarkers, which were identified only on pottery from Moverna vas. Other prehistoric finds of birch-bark tar from Slovenian archaeological sites include a lump of tar in sediment from Ajdovska jama, and occurrences with pottery have been reported from other Neolithic and Bronze Age sites in Slovenia.

The analysis of pottery typology and lipid residues showed that some vessels types can be linked to specific foodstuffs or food preparation techniques. Midchain ketones, biomarkers for exposure to high temperature, were observed only in vessel types of larger volume or openness of rim (i.e. pots, bowls and dishes). High lipid concentrations detected in pedestal dishes, cups and pots suggest intensive use with fatty foods, while bowls, jugs and dishes were perhaps used only as storage or serving vessels for less fatty commodities.

\section{ACKNOWLEDGEMENTS}

This research was financially supported by the European SOCRATES exchange programme, which enabled LکS to undertake the analysis at the Organic Geochemistry Unit in Bristol, UK in October 2006 and April 2007. Thanks are due to the UK Natural Environment Research Council for their support of mass spectrometry facilities to the Bristol node of NERC Life Sciences Mass Spectrometry Facility and also to Ian Bull and Rob Berstan for their invaluable assistance with the instrumental analysis. 


\section{References}

Aillaud S. 2001. Field and laboratory studies of diagenetic reactions affecting lipid residues absorbed in unglazed archaeological pottery vessels. University of Bristol. Bristol.

Albarella U., Serjeantson D. 2002. A passion for pork: Meat consumption at the British Late Neolithic site of Durrington Walls. In P. Miracle., N. Milner (eds.), Consuming Passions and patterns of consumption. Monographs of the McDonald Institute. Cambridge.

Andrič M. 2007. Holocene vegetation development in Bela Krajina (Slovenia) and the impact of first farmers on the landscape. The Holocene 17(6): 763-776.

Barfield L. 1972. The first Neolithic cultures of Northeastern Italy. Fundamenta A/3, Teil 7: 182-216.

Bianchi G. 1995. Plant waxes. In R. J. Hamilton (ed.), Waxes: Chemistry, Molecular Biology and Functions. The Oily Press. Dundee: 175-222.

Boast R. 2002. Pots as Categories: British Beakers. In A. Woodward, J. D. Hill (eds.), Prehistoric Britain. The Ceramic Basis. Oxbow Books. Oxford.

Bonsall C., Horvat M., McSweeney K., Masson M., Higham T. F. G., Pickard C. and Cook G. T. 2007. Chronological and dietary aspects of the human burials from Ajdovska cave, Slovenia. Radiocarbon 49(2): 727-740.

Bonsall C., Mlekuž D., Bartosiewicz L. and Pickard C. 2013. Early Farming Adaptations of the Northeast Adriatic Karst. In S. Colledge, J. Conolly, K. Dobney, K. Manning and S. Shennan (eds.), Domestic Animals in Southwest Asia and Europe. Left Coast Press. Walnut Creek, CA: 145-160.

Bosque D., Regert M., Dubois N. and Jadin I. 2001. Identification de bai de bouleau sur quatre vases du site urbane de Fexhe-le-Haut-Clocher "Podri l'Cortri". Premiers resultants. Notae Praehistoricae 21: 119-127.

Budja M. 1989. Arheološki zapisi na površju, palimpsesti preteklih stanj. Poročilo o raziskovanju paleolita, neolita in eneolita $v$ Sloveniji 17: 83-102.

1994. Neolithic studies in Slovenia: an overview. Atti della Società per la Preistoria e Protostoria della Regione Friuli-Venezia Giulia 8: 7-28.

1995. Neolithic and Eneolithic settlement patterns in the Bela krajina Region of Slovenia. In Memorie del Museo civico di storia naturale di Verona. Sezione scienze dell'uomo 4: 119-127.
Budja M., Ogrinc N., Žibrat Gašparič A., Potočnik D., Žigon D. and Mlekuž D. 2013. Transition to farming - transition to milk culture: a case study from Mala Triglavca, Slovenia. Documenta Praehistorica 40: 97-117.

Charters S., Evershed R. P., Goad L. J., Leyden A., Blinkhorn P. W. and Denham V. 1993a. Quantification and distribution of lipid in archaeological ceramics: implications for sampling potsherds for organic residue analysis and the classification of vessel use. Archaeometry 35: 211-223.

Charters S., Evershed R. P., Goad L. J., Heron C. and Blinkhorn P. 1993b. Identification of an adhesive used to repair a roman jar. Archaeometry 35: 91-101.

Charters S., Evershed R. P., Blinkhorn P. W. and Denham V. 1995. Evidence for the mixing of fats and waxes in archaeological ceramics. Archaeometry 37: 113-127.

Charters S., Evershed R. P., Quye A., Blinkhorn P. W. and Reeves V. 1997. Simulation experiments for determining the use of ancient pottery vessels: The behaviour of epicuticular leaf wax during boiling of a leafy vegetable. Jour nal of Archaeological Science 24: 1-7.

Copley M. S., Berstan R., Dudd S. N., Docherty G., Mukherjee A. J., Straker V., Payne S. and Evershed R. P. 2003. Direct chemical evidence for widespread dairying in prehistoric Britain. Proceedings of the National Academy of Sciences 100: 1524-1529.

Copley M. S., Hansel F. A., Sadr K. and Evershed R. P. 2004. Organic residue evidence for the processing of marine animal products in pottery vessels from the pre-colonial archaeological site of Kasteelberg D east, South Africa. South African Journal of Science 100: 279-283.

Copley M. S., Bland H. A., Rose P., Horton M. and Evershed R. P. 2005a. Gas chromatographic, mass spectrometric and stable carbon isotopic investigations of organic residues of plant oils and animal fats employed as illuminants in archaeological lamps from Egypt. Analyst 130: $860-871$

Copley M. S., Berstan R., Dudd S. N., Aillaud S., Mukherjee A. J., Straker V., Payne S. and Evershed R. P. 2005b. Processing of milk products in pottery vessels through British prehistory. Antiquity 79: 895-908.

Craig 0. E. 2004. Organic analysis of «food crusts» from sites in the Schelde valley, Belgium: a preliminary evaluation. Notae Praehistoricae 24: 209-221.

Craig 0. E., Chapman J., Heron C., Willis L. H., Bartosiewicz L., Taylor G., Whittle A. and Collins M. J. 2005. Did 
the first farmers of central and eastern Europe produce dairy foods? Antiquity 79: 882-894.

Craig 0. E., Steele V. J. and Fischer A. 2011. Ancient lipids reveal continuity in culinary practices across the transition to agriculture in Northern Europe. Proceedings of the National Academy of Sciences 108: 17910-17915.

Cramp L. J. E., Evershed R. P. 2014. Reconstructing Aquatic Resource Exploitation in Human Prehistory using Lipid Biomarkers and Stable Isotopes. In H. D. Holland, K. K. Turekian (eds.), Treatise on Geochemistry: Archaeology and Anthropology. Elsevier. Oxford: 319-339.

Cramp L. J. E., Jones J., Sheridan A., Smyth J., Whelton H., Mulville J., Sharples N. and Evershed R. P. 2014. Immediate replacement of fishing with dairying by the earliest farmers of the northeast Atlantic archipelagos. Proceedings of the Royal Society B(281): 20132372.

David N. 1972. On the Life Span of Pottery, Type Frequencies, and Archaeological Inference. American Antiquity 37: 141-142.

DeBoer W. R. 1974. Ceramic Longevity and Archaeological Interpretation: An Example from the Upper Ucayali, Peru. American Antiquity 39: 335-343.

Dineley M. 2011. Experiment or Demonstration? Making fermentable malt sugars from the grain and discussion of some of the evidence for this activity in the British Neolithic. In D. Millson (ed.), Experimentation and Interpretation: use of experimental archaeology in the study of the past. Oxbow Books. Oxford: 96-108.

Dineley M., Dineley G. 2000. Neolithic Ale: Barley as a source of sugars for fermentation. In A. Fairbarn (ed.), Plants in the Neolithic and Beyond. Oxbow Books. Oxford: 137-155.

Dudd S. N., Evershed R. P. 1998. Direct demonstration of milk as an element of archaeological economies. Science 282: $1478-1481$.

Dudd S. N., Evershed R. P. and Gibson A. M. 1999. Evidence for Varying Patterns of Exploitation of Animal Products in Different Prehistoric Pottery Traditions Based on Lipids Preserved in Surface and Absorbed Residues. Journal of Archaeological Science 26: 1473-1482.

Dunne J., Evershed R. P., Salque M., Cramp L., Bruni S., Ryan K., Biagetti S. and Di Lernia S. 2012. First dairying in green Saharan Africa in the fifth millennium BC. $\mathrm{Na}$ ture 486: 390-394.

Eerkens J. 2002. The preservation and identification of piñon resins by GC-MS in pottery from the western Great Basin. Archaeometry 44: 95-105.
Evans K. M., Heron C. 1993. Glue, disinfectant and chewing gum: natural products chemistry in archaeology. Chemistry and Industry 12: 446-449.

Evershed R. P. 2008a. Organic residue analysis in archaeology: the archaeological biomarker revolution. Archaeometry 50: 895-924.

2008b. Experimental approaches to the interpretation of absorbed organic residues in archaeological ceramics. World Archaeology 40: 26-47.

Evershed R. P., Jerman K. and Eglinton G. 1985. Pine wood origin for pitch from the Mary Rose. Nature 314: 528-530.

Evershed R. P., Heron C. and Goad L. J. 1990. Analysis of organic residues of archaeological origin by high-temperature gas-chromatography and gas-chromatography massspectrometry. Analyst 115: 1339-1342.

1991. Epicuticular wax components preserved in potsherds as chemical indicators of leafy vegetables in ancient diets. Antiquity 65: 540-544.

Evershed, R. P., Heron C., Charters S. and Goad L. J. 1992. The Survival of Food Residues: New Methods of Analysis, Interpretation and Application. In A. M. Pollard (ed.), New Developments in Archaeological Science. Proceedings of the British Academy 77: 187-208.

Evershed R. P., Arnot K. I., Collister J., Eglinton G. and Charters S. 1994. Application of isotope ratio monitoring gas-chromatography mass-spectrometry to the analysis of organic residues of archaeological origin. Analyst 119: 909-914.

Evershed R. P., Stott A. W., Raven A., Dudd S. N., Charters S. and Leyden A. 1995. Formation of Long-Chain Ketones in Ancient Pottery Vessels by Pyrolysis of Acyl Lipids. Tetrahedron Letters 36: 8875-8878.

Evershed R. P., Vaughan S. J., Dudd S. N. and Soles J. S. 1997. Fuel for thought? Beeswax in lamps and conical cups from Late Minoan Crete. Antiquity 71: 979-985.

Evershed R. P., Dudd S. N., Charters S., Mottram H., Stott A. W., Raven A. M., Van Bergen P. F. and Bland H. A. 1999. Lipids as carriers of anthropogenic signals from prehistory. Philosophical Transactions of the Royal Society of London B: Biological Sciences 354: 19-31.

Evershed R. P., Dudd S. N., Copley M. S., Berstan R., Stott A. W., Mottram H., Buckley S. A. and Crossman Z. 2002. Chemistry of archaeological animal fats. Accounts of chemical research 35: 660-668. 
Evershed R. P., Dudd S. N., Anderson-Stojanovic V. R. and Gebhard E. R. 2003. New Chemical Evidence for the Use of Combed Ware Pottery Vessels as Beehives in Ancient Greece. Journal of Archaeological Science 30: 1-12.

Evershed R. P. and 21 authors 2008c. Earliest date for milk use in the Near East and southeastern Europe linked to cattle herding. Nature 445: 528-531.

Evershed R. P., Copley M. S., Dickson L. and Hansel F. A. 2008d. Experimental evidence for the processing of marine animal products and other commodities containing polyunsaturated fatty acids in pottery vessels. Archaeometry 50: 101-113.

Farquhar G. D., Ehleringer J. R. and Hubick K. T. 1989. Carbon isotope discrimination and photosynthesis. Annual Review of Plant Physiology and Plant Molecular Biology 40: 503-537.

Foster G. M. 1960. Life-Expectancy of Utilitarian Pottery in Tzintzuntzan, Michoacan, Mexico. American Antiquity 25: 606-609.

Gibson A. 2002. Prehistoric Pottery in Britain and Ireland. Tempus Publishing Ltd. Stroud.

Hadži D., Cvek F. 1976. Smolni kit in premaz za žare. $A r$ heološki vestnik 27: 128-134.

Hadži D., Orel B. 1978. Spektrometrične raziskave izvora jantarja in smol iz prazgodovinskih najdišč na Slovenskem. Vestnik Slovenskega Kemijskega Društva 25(1): 51-62.

Hansel F. A., Copley M. S., Madureira L. A. S. and Evershed R. P. 2004. Thermally produced $\omega$-(o-alkylphenyl) alkanoic acids provide evidence for the processing of marine products in archaeological pottery vessels. Tetrahedron Letters 45: 2999-3002.

Hedges R. E. M., Tiemei C. and Housley R. A. 1992. Results and methods in the radiocarbon dating of pottery. Radiocarbon 34(3): 906-915.

Heron C., Evershed R. P. 1993. The Analysis of Organic Residues and the Study of Pottery Use. Archaeological Method and Theory 5: 247-284.

Heron C., Nemcek N. and Bonfield K. M. 1994. The chemistry of Neolithic beeswax. Naturwissenschaften 81: $266-$ 269.

Hill J. D. 2002. Pottery and the Expression of Society, Economy and Culture. In A. Woodward, J. D. Hill (eds.), Prehistoric Britain. The Ceramic Basis. Oxbow Books. Oxford.
Horvat M. 1989. Ajdovska jama pri Nemški vasi. Razprave Filozofske fakultete. Znanstveni inštitut Filozofske fakultete. Ljubljana.

Kimpe K., Jacobs P. A. and Waelkens M. 2002. Mass spectrometric methods prove the use of beeswax and ruminant fats in late Roman cooking pots. Journal of Chromatography A 968: 151-160.

Kolattukudy P. E., Croteau R. and Buckner J. S. 1976. Biochemistry of plant waxes. In P. E. Kolattukudy (ed.), Chemistry and biochemistry of natural waxes. Elsevier. Oxford: 93-146.

Longacre W. A. 1991. Sources of Ceramic Variability Among the Kalinga of Northern Luzon. In W. A. Longacre (ed.), Ceramic Ethnoarchaeology. The University of Arizona Press. Tucson: 95-111.

Lucquin A., March R. J. and Cassen S. 2007. Analysis of adhering organic residues of two "coupes-à-socles" from the Neolithic funerary site "La Hougue Bie" in Jersey: evidences of birch bark tar utilisation. Journal of Archaeological Science 34: 704-710.

McGovern P. E., Mirzoian A. and Hall G. R. 2009. Ancient Egyptian herbal wines. Proceedings of the National Academy of Sciences 106: 7361-7366.

Mills J. S. and White R. (eds.) 1994. The organic chemistry of museum objects, $2^{\text {nd }} \mathrm{Ed}$. Butterworths. London: 49-55.

Millson D. 2011. Introduction. In D. Millson (ed.), Experimentation and Interpretation: the Use of Experimental Archaeology in the Study of the Past. Oxbow books. 0xford: 1-6.

Miracle P. T., Forenbaher S. 2005. Neolithic and BronzeAge Herders of Pupičina Cave, Croatia. Journal of Field Archaeology 30: 255-281.

Miracle P. T., Pugsley L. 2006. Vertebrate faunal remains from Pupičina Cave. In P. T. Miracle, S. Forenbaher (eds.), Prehistoric herders of northern Istria: the archaeology of Pupičina Cave. Vol. 1. Arheološki Muzej Istre. Pula: 259-399.

Mlekuž D. 2005. The ethnography of the Cyclops: Neolithic pastoralist in the eastern Adriatic. Documenta Praehistorica 32: 15-51.

2006. Meat or milk? Neolithic economies of Caput Adriae. Preistoria dell'Italia settentrionale. Studi in ricordo di Bernardino Bagolini, Atti del Convegno, Udine settembre 2005: 453-458. 
Mlekuž D., Žibrat Gašparič A., Horvat M. and Budja M. 2012. Houses, pots and food: the pottery from Maharski prekop in context. Documenta Praehistorica 39: 325338.

Mlekuž D., Ogrinc N., Horvat M., Žibrat Gašparič A., Gams Petrišič M. and Budja M. 2013. Pots and food: uses of pottery from Resnikov prekop. Documenta Praehistorica 40: $131-146$.

Mottram H. R., Dudd S. N., Lawrence G. J., Stott A. W. and Evershed R. P. 1999. New chromatographic, mass spectrometric and stable isotope approaches to the classification of degraded animal fats preserved in archaeological pottery. Journal of Chromatography A(833): 209-221.

Mukherjee A. J., Berstan R., Copley M. S., Gibson A. M. and Evershed R. P. 2007. Compound-specific stable carbon isotopic detection of pig product processing in British Late Neolithic pottery. Antiquity 81: 743-754.

Ogrinc N., Budja M. 2005. Paleodietary reconstruction of a Neolithic population in Slovenia: a stable isotope approach. Chemical geology 218: 103-116.

Ogrinc N., Gams Petrišič M., Žigon D., Žibrat Gašparič A. and Budja M. 2012. Pots and lipids: molecular and isotope evidence of food processing at Maharski prekop. Documenta Praehistorica 39: 339-347.

Oinonen M., Pesonen P. and Tallavaara M. 2010. Archaeological radiocarbon dates for studying the Population history in Eastern Fennoscandia. Radiocarbon 52: 393-407.

Orton C., Tyers P. and Vince A. 1993. Pottery in Archaeology. Cambridge University Press. Cambridge.

Osterc V. 1986. Mineralogija keramike iz Ajdovske jame I. Poročilo o raziskovanju paleolita, neolita in eneolita $v$ Sloveniji 14: 97-110.

Outram A. K., Stear N. A., Bendrey R., Olsen S., Kasparov A., Zaibert V., Thorpe N. and Evershed R. P. 2009. The Earliest Horse Harnessing and Milking. Science 323: 1332-1335.

Payne S. 1973. Kill-off Patterns in Sheep and Goats: The Mandibles from Așvan Kale. Anatolian Studies 23: 281303.

Pollard M., Heron C. 1996. The Chemistry and use of resinous substances. In M. Pollard, C. Heron (eds.), Archaeological Chemistry. Royal Society of Chemistry. London: 239-255.

Puš I. 1976. Premazi in smolnati kit na prazgodovinskih posodah. Arheološki vestnik 27: 124-127.
Raven A. M., Van Bergen P. F., Stott A. W., Dudd S. N. and Evershed R. P. 1997. Formation of long-chain ketones in archaeological pottery vessels by pyrolysis of acyl lipids. Journal of Analytical and Applied Pyrolysis 40-41: 267285.

Regert M. 2004. Investigating the history of prehistoric glues by gas chromatography-mass spectrometry. Journal of Separation Science 27: 244-254.

Regert M., Rolando C. 2002. Identification of archaeological adhesives using direct inlet electron ionization mass spectrometry. Analytical Chemistry 74: 965-975.

Regert M., Bland H. A., Dudd S. N., Van Bergen P. F. and Evershed R. P. 1998. Free and bound fatty acid oxidation products in archaeological ceramic vessels. Proceedings of the Royal Society in London B: Biological Sciences 265: 2027-2032.

Regert M., Colinart S., Degrand L. and Decavallas 0. 2001. Chemical alteration and use of beeswax through time: accelerated ageing tests and analysis of archaeological samples from various environmental contexts. Archaeometry 43: 549-569.

Regert M., Garnier N., Decavallas 0., Cren-Olive C. and Rolando C. 2003a. Structural characterization of lipid constituents from natural substances preserved in archaeological environments. Measurement Science and Technology 14: $1620-1630$.

Regert M., Vacher S., Moulherat C. and Decavallas 0. $2003 \mathrm{~b}$. Adhesive production and pottery function during the Iron age at the site of Grand Aunay. Archaeometry 45: $101-120$

Rice P. M. 1987. Pottery Analysis. A Sourcebook. University of Chicago Press. Chicago.

Robinson N., Evershed R. P., Higgs W. J., Jerman K. and Eglinton G. 1987. Proof of a pine wood origin for pitch from Tudor (Mary Rose) and Etruscan shipwrecks: application of analytical organic chemistry in archaeology. Analyst 112: 637-643.

Romanus K., Baeten J., Poblome J., Accardo S., Degryse P., Jacobs P., De Vos D. and Waelkens M. 2009. Wine and olive oil permeation in pitched and non-pitched ceramics: relation with results from archaeological amphorae from Sagalassos, Turkey. Journal of Archaeological Science 36: 900-909.

Romanus K., Poblome J., Verbeke K., Luypaerts A., Jacobs P., De Vos D. and Waelkens M. 2007. An evaluation of analytical and interpretative methodologies for the extraction and identification of lipids associated with pot- 
tery sherds from the site of Sagalassos, Turkey. Archaeometry 49: 729-747.

Rowley-Conwy P., Gourichon L., Helmer D. and Vigne J.D. 2013. Early domestic animals in Italy, Istria, the Tyrrhenian Islands and Southern France. In S. Colledge, J. Conolly, K. Dobney, K. Manning and S. Shennan (eds.), Domestic Animals in Southwest Asia and Europe. Left Coast Press. Walnut Creek, CA: 161-194.

Salque M., Bogucki P. I., Pyzel J., Sobkowiak-Tabaka I., Grygiel R., Szmyt M. and Evershed R. P. 2013. Earliest evidence for cheese making in the sixth millennium BC in northern Europe. Nature 493: 522-525.

Saul H., Madella M., Fischer A., Glykou A., Hartz S. and Craig O. E. 2013. Phytoliths in Pottery Reveal the Use of Spice in European Prehistoric Cuisine. PLOS ONE 8: e70583.

Šercelj A., Culiberg M. 1984. Rastlinski ostanki iz Ajdovske jame pri Nemški vasi. Poročilo o raziskovanju paleolita, neolita in eneolita $v$ Sloveniji 12: 33-35.

Skibo J. M., Feinman G. M. 1999. Pottery and People. A Dynamic Interaction. University of Utah Press. Salt Lake City.

Šoberl L., Žibrat Gašparič A., Budja M. and Evershed R. P. 2008. Early herding practices revealed through organic residue analysis of pottery from the early Neolithic rock shelter of Mala Triglavca, Slovenia. Documenta Praehistorica 35: 253-260.

Sraka M. 2013. ${ }^{14} \mathrm{C}$ dates and stratigraphy: reconsidering the sequences at Moverna vas (Bela Krajina, southeastern Slovenia). Documenta Praehistorica 40: 313-332.
Tite M. S. 2008. Ceramic production, provenance and use - a review. Archaeometry 50: 216-231.

Tomaž A. 1997. Tehnološka raziskava lončenine iz Moverne vasi v Beli Krajini. Poročilo o raziskovanju paleolitika, neolitika in eneolitika v Sloveniji 24: 113-142.

1999. Časovna in prostorska strukturiranost neolitskega lončarstva: Bela krajina, Ljubljansko barje, Dinarski kras. Unpublished Master thesis. Faculty of Arts. University of Ljubljana. Ljubljana.

Tulloch A. P. 1976. Chemistry of waxes of higher plants. In P. E. Kolattukudy (ed.), Chemistry and biochemistry of natural waxes. Elsevier. Oxford: 235-287.

Urem-Kotsou D., Stern B., Heron C. and Kotsakis K. 2002. Birch-bark tar at Neolithic Makriyalos, Greece. Antiquity 76: 962-967.

Vlaemnick B., Fievez V., Cabrita A. R. J., Fonseca A. J. M. and Dewhurst R. J. 2006. Factors affecting odd- and branched-chain fatty acids in milk: A review. Animal Feed Science and Technology 131: 389-417.

Žibrat Gašparič A. 2004. Archaeometrical analysis of Neolithic pottery from the Divača region, Slovenia. Documenta Praehistorica 31: 205-220.

2008. Strukturna analiza neolitske keramike in lončarske tehnologije. Unpublished $\mathrm{PhD}$ thesis. Faculty of Arts. University of Ljubljana. Ljubljana. 


\section{Appendix}

App. 1. Details of ceramic assemblages investigated.

\begin{tabular}{|c|c|c|c|c|c|c|}
\hline $\begin{array}{l}\text { Sample } \\
\text { \# CHEM }\end{array}$ & $\begin{array}{l}\text { Sample } \\
\text { \# ARCH }\end{array}$ & Site code & SF \# & $\begin{array}{l}\text { SE/rel. } \\
\text { depth }\end{array}$ & Sector/quadrant & Description \\
\hline $\mathrm{OIAJ}$ & 1 & Ajdovska jama 1982 & $129 a$ & 42 & LH/tunnel 1 & body of a pot, bucket- shaped \\
\hline $\mathrm{O} 2 \mathrm{AJ}$ & 2 & Ajdovska jama 1982 & 684 & 43 & CDV/XXII, group 4 & body of a pot \\
\hline $\mathrm{O} 3 \mathrm{AJ}$ & 3 & Ajdovska jama 1982 & $567 / 2$ & 43 & CDV/XXII, group 4 & body of a dish \\
\hline $\mathrm{O} 4 \mathrm{AJ}$ & 4 & Ajdovska jama 1982 & $660(2519)$ & 43 & CDV/XVI, group 4 & body of a pot \\
\hline $05 \mathrm{AJ}$ & 5 & Ajdovska jama 1982 & 682 & 43 & CDV/XVI, group 4 & body of a dish \\
\hline o6AJ & 6 & Ajdovska jama 1982 & 146 & 44 & LH/tunnel 1 & body of a pot \\
\hline $\mathrm{O} 7 \mathrm{AJ}$ & 7 & Ajdovska jama 1982 & 43 & 43 & LH/tunnel 2 & body of a pot \\
\hline $31 \mathrm{AJ}$ & 8 & Ajdovska jama 1976 & 208 & 43 & LH/group 6 & body of a pedestal dish \\
\hline $32 \mathrm{Al}$ & 9 & Ajdovska jama 1982 & 70 & l & $\mathrm{DH} / 33$ & $\begin{array}{l}\text { body with base of a dish, black residue } \\
\text { on exterior }\end{array}$ \\
\hline $33 \mathrm{Al}$ & 10 & Ajdovska jama 1986/87 & 633 & 43 & CDV/XVIa, group 4 & $\begin{array}{l}\text { body of a pedestal dish, modern glue } \\
\text { residue }\end{array}$ \\
\hline $34 \mathrm{AJ}$ & 11 & Ajdovska jama 1986 & 640 & 42 & $\mathrm{CDV} / \mathrm{XXII}$ & upper body of a pedestal dish \\
\hline $35 \mathrm{AJ}$ & 12 & Ajdovska jama 1967 & 262 & 43 & LH/group 6 & $\begin{array}{l}\text { base of a pedestal dish, traces of a red } \\
\text { slip on exterior }\end{array}$ \\
\hline $36 \mathrm{AJ}$ & 13 & Ajdovska jama 1967 & 284 & 43 & LH/group 6 & body of a dish \\
\hline $37 \mathrm{Al}$ & 14 & Ajdovska jama 1988 & 730 & 43 & CDV/XXIVa, group 4 & $\begin{array}{l}\text { base with body of a spouted dish, yel- } \\
\text { lowish residue perhaps on interior }\end{array}$ \\
\hline $38 \mathrm{Al}$ & 15 & Ajdovska jama 1986 & 577 & 43 & CDV/XVI, XIIa, group 4 & $\begin{array}{l}\text { rim of a spouted dish, black residue on } \\
\text { interior, shiny surface - perhaps con- } \\
\text { solidant? }\end{array}$ \\
\hline $39 \mathrm{Al}$ & 16 & Ajdovska jama 1986 & 576 & 42 & $\begin{array}{l}\text { CDV/ XXIX/XXVIII; } \\
\text { XXVIII }\end{array}$ & rim of a dish, modern glue residue \\
\hline $4 \circ \mathrm{AJ}$ & 17 & Ajdovska jama 1967 & 274 & 42 & $\mathrm{LH}$ & $\begin{array}{l}\text { body of a spouted dish, modern glue } \\
\text { present }\end{array}$ \\
\hline $41 \mathrm{AJ}$ & 18 & Ajdovska jama 1985-87 & 575 & 43 & $\begin{array}{l}\text { CDV/XXII,XXIIa, XXIX, } \\
\text { group } 4\end{array}$ & rim of a dish \\
\hline $42 \mathrm{AJ}$ & 19 & Ajdovska jama 1985/86 & 635 & 43 & CDV/XXIIa, group 4 & rim of a bowl, modern glue present \\
\hline $43 \mathrm{Al}$ & 20 & Ajdovska jama 1986 & 574 & 42 & CDV/XVI & $\begin{array}{l}\text { rim of a dish, unusual surface - orga- } \\
\text { nic residue, limescale or consolidant? }\end{array}$ \\
\hline $44 \mathrm{AJ}$ & 21 & Ajdovska jama 1967 & 273 & 43 & LH/group 6 & body of a spouted dish \\
\hline $45 \mathrm{Al}$ & 22 & Ajdovska jama 1967 & 245 & 42 & LH & $\begin{array}{l}\text { body of a spouted dish, modern glue } \\
\text { present }\end{array}$ \\
\hline $46 \mathrm{AJ}$ & 23 & Ajdovska jama 1982 & 122 & 42 & LH/tunnel 1 & $\begin{array}{l}\text { rim of a dish with an appliqué decora- } \\
\text { tion }\end{array}$ \\
\hline $47 \mathrm{AJ}$ & 24 & Ajdovska jama 1982 & 119 & 44 & LH/group 1 & body of a dish, ribbed decoration \\
\hline $48 \mathrm{AJ}$ & 25 & Ajdovska jama 1986 & 584 & 42 & CDV/XXIX & $\begin{array}{l}\text { body of a bowl (by fireplace } \mathrm{SE}_{56} 6 \text { ), rib- } \\
\text { bed decoration }\end{array}$ \\
\hline $49 \mathrm{AJ}$ & 26 & Ajdovska jama 1985 & 583 & 43 & CDV/XXII, group 4 & rim of a bowl \\
\hline $50 \mathrm{Al}$ & 27 & Ajdovska jama 1986 & 586 & 1 & $\mathrm{CDV} / \mathrm{X} / \mathrm{IX}, \mathrm{XV}, \mathrm{XXIX}$ & body of a ribbed dish \\
\hline $51 \mathrm{AJ}$ & 28 & Ajdovska jama 1982/83 & 109 & 42 & LH/tunnel 1 & body of a spouted dish \\
\hline $52 \mathrm{AJ}$ & 30 & Ajdovska jama 1982 & 126 & 42 & $\mathrm{LH} /$ tunnel 1 & body of a bowl, bucket-shaped \\
\hline $53 \mathrm{AJ}$ & 32 & Ajdovska jama 1967 & 258 & 43 & LH/group 6 & body with base of a spouted bowl \\
\hline $54 \mathrm{Al}$ & 33 & Ajdovska jama 1985 & 440 & 43 & CDV/XVI,XXII, group 4 & rim of a jug \\
\hline $55 \mathrm{Al}$ & 34 & Ajdovska jama 1967 & 267 & 43 & LH/group 6 & $\begin{array}{l}\text { body of a jug with a horizontal rib and } \\
\text { incised decoration }\end{array}$ \\
\hline $56 \mathrm{AJ}$ & 35 & Ajdovska jama 1967 & 206 & 43 & LH/group 6 & base of a jug \\
\hline $57 \mathrm{AJ}$ & 36 & Ajdovska jama 1967 & 257 & 43 & LH/group 6 & body of a jug \\
\hline 58AJ-1 & 29 & Ajdovska jama 1987 & 739 & 44 & CDV/XXII,XXIIa,XVIa & $\begin{array}{l}\text { body of a pot, burnt residue on interi- } \\
\text { or and exterior }\end{array}$ \\
\hline $58 \mathrm{AJ}-2$ & 29 & Ajdovska jama 1987 & 739 & 44 & CDV/XXII,XXIIa,XVIa & $\begin{array}{l}\text { body of a pot, burnt residue on inte- } \\
\text { rior and exterior }\end{array}$ \\
\hline 59AJ & 31 & Ajdovska jama 1984 & 116 & 42 & LH/tunnel 1 & body of a pot, bucket-shaped \\
\hline $6 \circ \mathrm{Al}$ & 37 & Ajdovska jama 1985-87 & 743 & 43 & $\begin{array}{l}\text { CDV/XXII,XXIIa,XVI, } \\
\text { group } 4\end{array}$ & rim of a pot with incised decoration \\
\hline
\end{tabular}


Lucija Šoberl, Milena Horvat, Andreja Žibrat Gašparič, Marko Sraka, Richard Evershed and Mihael Budja

\begin{tabular}{|c|c|c|c|c|c|c|}
\hline $\begin{array}{l}\text { Sample } \\
\text { \# CHEM }\end{array}$ & $\begin{array}{r}\text { Sample } \\
\text { \# ARCH }\end{array}$ & Site code & SF \# & $\begin{array}{l}\text { SE/rel. } \\
\text { depth }\end{array}$ & Sector/quadrant & Description \\
\hline $61 \mathrm{AJ}$ & 38 & Ajdovska jama 1986/87 & 756 & 43 & CDV/XXIla, group 4 & $\begin{array}{l}\text { two rims of a pot - one with a horizon- } \\
\text { tal rib, one with criss-cross incisions }\end{array}$ \\
\hline $62 \mathrm{AJ}$ & 39 & Ajdovska jama 1985 & 737 & 43 & CDV/XXII, group 4 & $\begin{array}{l}\text { body of a pot with horizontal incisions } \\
\text { and a base of the handle (similar in } \\
\text { Moverna vas assemblage) }\end{array}$ \\
\hline $63 \mathrm{Al}$ & 40 & Ajdovska jama 1982 & 120 & 44 & LH/group 1 & $\begin{array}{l}\text { three body fragments of a pot with a } \\
\text { zoomorphic head }\end{array}$ \\
\hline$\overline{64 \mathrm{AJ}}$ & 41 & Ajdovska jama 1984 & 385 & 83 & CDV/XVIII & rim with body of a pot \\
\hline $65 \mathrm{AJ}$ & 42 & Ajdovska jama 1987 & 641 & 43 & CDV/XXIIa, group 4 & body of a pot \\
\hline$\overline{66 \mathrm{AJ}}$ & 43 & Ajdovska jama 1985 & 564 & 43 & CDV/XXII, XVI, group 4 & rim of a pot with vertical incisions \\
\hline $67 \mathrm{AJ}$ & 44 & Ajdovska jama 1985/86 & 455 & 43 & $\begin{array}{l}\text { CDV/XVI,XXII,XXIIa, } \\
\text { group } 4\end{array}$ & base of a pot, painted decoration \\
\hline $68 \mathrm{AJ}$ & 45 & Ajdovska jama 1982 & 125 & 44 & LH/group 1 & body of a pot \\
\hline $69 \mathrm{AJ}$ & 46 & Ajdovska jama 1982 & 107 & 42 & LH/tunnel 1 & body of a pot \\
\hline $70 \mathrm{AJ}$ & 47 & Ajdovska jama $1967 / 82$ & 670 & 44 & LH/group 1 & body of a large pot (pythos) \\
\hline 71AJ & 48 & Ajdovska jama 1982 & 198 & 43 & LH/group 2 & body of a pot \\
\hline $72 \mathrm{AJ}$ & 49 & Ajdovska jama $1985-87$ & 606 & 44 & $\mathrm{CDV} / \mathrm{XXII}, \mathrm{XVI}$, group 3 & $\begin{array}{l}\text { body of a pot, red slip on exterior, burnt } \\
\text { interior }\end{array}$ \\
\hline $73 \mathrm{Al}$ & 50 & Ajdovska jama 1982 & 129 & 43 & LH/tunnel 1 & body of a pot, bucket-shaped \\
\hline$\overline{74 \mathrm{AJ}}$ & 51 & Ajdovska jama & 703 & $?$ & $\mathrm{CDV} / 22$ & body of a pot, ribbed decoration \\
\hline $8 \mathrm{MT}$ & 1 & Mala Triglavca 2006 & PN1690 & 55 & $\mathrm{~A} / \mathrm{Lg} / \mathrm{a}$ & body, unwashed, undefined type \\
\hline $9 \mathrm{MT}$ & 1 & Mala Triglavca 2006 & $\mathrm{PN} 1722$ & 55 & $\mathrm{~A} / \mathrm{Lg} 2 / \mathrm{a}$ & body, unwashed, undefined type \\
\hline 10MT & 1 & Mala Triglavca 2006 & $\mathrm{PN} 1697$ & 55 & $\mathrm{~A} / \mathrm{K} 93 / \mathrm{C}$ & body, undefined type \\
\hline $11 \mathrm{MT}$ & 1 & Mala Triglavca 2006 & $\mathrm{PN} 1752$ & 55 & $\mathrm{~A} / \mathrm{K} 91 / \mathrm{C}$ & body, undefined type \\
\hline $12 \mathrm{MT}$ & 1 & Mala Triglavca 2006 & $\mathrm{PN} 1694$ & 55 & $\mathrm{~A} / \mathrm{L} 93 / \mathrm{a}$ & body, undefined type \\
\hline $13 \mathrm{MT}$ & I & Mala Triglavca 2006 & $\mathrm{PN} 1714$ & 55 & $\mathrm{~A} / \mathrm{Kg} / \mathrm{C}$ & rim, undefined type \\
\hline 14MT & 1 & Mala Triglavca 2006 & $\mathrm{PN} 1748$ & 55 & $\mathrm{~A} / \mathrm{L} 91 / \mathrm{a}$ & body, undefined type \\
\hline $15 \mathrm{MT}$ & 1 & Mala Triglavca 2006 & PN1561 & 47 & $\mathrm{~A} / \mathrm{L} 91 / \mathrm{d}$ & body, undefined type \\
\hline $16 \mathrm{MT}$ & 1 & Mala Triglavca 2006 & PN1680 & 55 & $\mathrm{~A} / \mathrm{Lg} 2 / \mathrm{d}$ & body, undefined type \\
\hline $17 \mathrm{MT}$ & 1 & Mala Triglavca 2006 & $\mathrm{PN} 1644$ & $47 / 51$ & $\mathrm{~A} / \mathrm{LgO} / \mathrm{a}$ & body, undefined type \\
\hline $18 \mathrm{MT}$ & 1 & Mala Triglavca 2006 & PN1829 & 61 & $A / L 91 / a$ & body, undefined type \\
\hline $75 \mathrm{MT}$ & 78 & Mala Triglavca & Ro43 & $2.90-3.05 \mathrm{~m}$ & $5,6,7$ & perforated rim, undefined type \\
\hline $76 \mathrm{MT}$ & 81 & Mala Triglavca & Ro44 & $2.90-3.05 \mathrm{~m}$ & $5,6,6$ & $\begin{array}{l}\text { base with body, burnt interior, unde- } \\
\text { fined type }\end{array}$ \\
\hline $77 \mathrm{MT}$ & 85 & Mala Triglavca & Ro45 & $2.90-3.05 \mathrm{~m}$ & $5,6,7$ & body of a pot \\
\hline $78 \mathrm{MT}$ & 86 & Mala Triglavca & Ro46 & $2.90-3.05 \mathrm{~m}$ & $5,6,7$ & body of a bowl, incised decoration \\
\hline $79 \mathrm{MT}$ & 101 & Mala Triglavca & Ro52 & $2.90-3.05 \mathrm{~m}$ & $5,6,7$ & body of a bowl, polished exterior \\
\hline $80 \mathrm{MT}$ & 103 & Mala Triglavca & Ro54 & $2.90-3.05 \mathrm{~m}$ & $5,6,7$ & $\begin{array}{l}\text { rim and body (two fragments), incised } \\
\text { decoration, undefined type }\end{array}$ \\
\hline $81 \mathrm{MT}$ & 112 & Mala Triglavca & Ro6o & $2.90-3.05 \mathrm{~m}$ & $5,6,7$ & body of a bowl, burnt interior \\
\hline $82 \mathrm{MT}$ & 140 & Mala Triglavca & Ro76 & $2.90-3.05 \mathrm{~m}$ & $5,6,7$ & base with body, undefined type \\
\hline $83 \mathrm{MT}$ & 169 & Mala Triglavca & Ro97 & $2.70-3.00 \mathrm{~m}$ & 4 & body of a dish \\
\hline $84 \mathrm{MT}$ & 335 & Mala Triglavca & $\mathrm{R} 178$ & $2.70-2.90 \mathrm{~m}$ & 3 & base with body, undefined type \\
\hline $85 \mathrm{MT}$ & 377 & Mala Triglavca & $\mathrm{R} 187$ & $2.60-2.75 \mathrm{~m}$ & $5,6,7$ & rim with body (two fragments) of a bowl \\
\hline $86 \mathrm{MT}$ & 440 & Mala Triglavca & R208 & $2.50-2.70 \mathrm{~m}$ & 4 & $\begin{array}{l}\text { rim with body, traces of a black slip, } \\
\text { undefined type }\end{array}$ \\
\hline $87 \mathrm{MT}$ & 459 & Mala Triglavca & R214 & $2.50-2.70 \mathrm{~m}$ & 4 & body of a cup, modern glue residue \\
\hline 88MT & 503 & Mala Triglavca & R230 & $2.60-2.80 \mathrm{~m}$ & 3 & $\begin{array}{l}\text { rim with body, burnt interior, unde- } \\
\text { fined type }\end{array}$ \\
\hline 89MT & 512 & Mala Triglavca & $\mathrm{R} 236$ & $2.30-2.50 \mathrm{~m}$ & 4 & $\begin{array}{l}\text { rim with body (two fragments), unde- } \\
\text { fined type }\end{array}$ \\
\hline $156 \mathrm{MT}$ & 20 & Mala Triglavca 1984 & Ro16 & $3.05-3.25 \mathrm{~m}$ & 5 & undefined type \\
\hline $157 \mathrm{MT}$ & 27 & Mala Triglavca 1984 & Ro21 & $3.05-3.25 \mathrm{~m}$ & 5 & pot \\
\hline $158 \mathrm{MT}$ & 36 & Mala Triglavca 1984 & Ro24 & $3.05-3.25 \mathrm{~m}$ & $5,6,7$ & bowl \\
\hline $159 \mathrm{MT}$ & 40 & Mala Triglavca 1984 & Ro27 & $3.05-3.25 \mathrm{~m}$ & $5,6,7$ & bowl \\
\hline 160MT & 59 & Mala Triglavca 1984 & Ro34 & $3.05-3.25 \mathrm{~m}$ & $5,6,7$ & bowl \\
\hline $161 \mathrm{MT}$ & 99 & Mala Triglavca 1984 & Ro50 & $2.90-3.05 \mathrm{~m}$ & $5,6,7$ & ladle \\
\hline $162 \mathrm{MT}$ & 159 & Mala Triglavca 1981 & Rogo & $2.70-3.00 \mathrm{~m}$ & 4 & bowl \\
\hline $163 \mathrm{MT}$ & 222 & Mala Triglavca 1981 & $\mathrm{R} 123 / 124$ & $2.70-3.00 \mathrm{~m}$ & 4 & handle fragment \\
\hline
\end{tabular}


Neolithic and Eneolithic activities inferred from organic residue analysis of pottery from Mala Triglavca, Moverna vas and Ajdovska jama...

\begin{tabular}{|c|c|c|c|c|c|c|}
\hline $\begin{array}{l}\text { Sample } \\
\text { \# CHEM }\end{array}$ & $\begin{array}{l}\text { Sample } \\
\text { \# ARCH }\end{array}$ & Site code & SF \# & $\begin{array}{l}\text { SE/rel. } \\
\text { depth }\end{array}$ & Sector/quadrant & Description \\
\hline $164 \mathrm{MT}$ & 238 & Mala Triglavca 1981 & $\mathrm{R} 133$ & $2.70-3.00 \mathrm{~m}$ & 4 & cup \\
\hline $165 \mathrm{MT}$ & 239 & Mala Triglavca 1981 & R134 & $2.70-3.00 \mathrm{~m}$ & 4 & bowl \\
\hline $166 \mathrm{MT}$ & 442 & Mala Triglavca 1981 & R210 & $2.50-2.70 \mathrm{~m}$ & 4 & pot \\
\hline $23 \mathrm{MV}-1$ & 1 & Moverna vas 1988 & 1238 & 053.1 & $5 / 13$ & visible black, charred residue, inside \\
\hline $23 \mathrm{MV}-2$ & I & Moverna vas 1988 & 1238 & 053.1 & $5 / 13$ & small bowl \\
\hline $24 \mathrm{MV}-1$ & I & Moverna vas 1988 & 2478 & 050.2 & $4 / 3$ & visible black, charred residue, inside \\
\hline $24 \mathrm{MV}-2$ & I & Moverna vas 1988 & 2478 & 050.2 & $4 / 3$ & $\begin{array}{l}\text { base with body of a pot, organic residue } \\
\text { on interior }\end{array}$ \\
\hline $25 \mathrm{MV}-1 \mathrm{~A}$ & 1 & Moverna vas 1988 & 1 & 050.1 & $6 / 1-116$ & visible black, compact residue, inside \\
\hline $25 \mathrm{MV}-1 \mathrm{~B}$ & I & Moverna vas 1988 & I & 050.1 & $6 / 1-116$ & visible brown, compact residue, inside \\
\hline $25 \mathrm{MV}-2$ & I & Moverna vas 1988 & I & 050.1 & $6 / 1-116$ & $\begin{array}{l}\text { base with body of a pot, organic residue } \\
\text { on interior }\end{array}$ \\
\hline $26 \mathrm{MV}-1$ & 1 & Moverna vas 1988 & 1 & 022.1 & $4 / 15$ & dark brown, compact residue, inside \\
\hline $26 \mathrm{MV}-2$ & I & Moverna vas 1988 & l & 022.1 & $4 / 15$ & $\begin{array}{l}\text { base with body of a pot, organic residue } \\
\text { on interior }\end{array}$ \\
\hline $27 \mathrm{MV}-1 \mathrm{~A}$ & 1 & Moverna vas 1988 & 6 & 050.1 & $5 / 6$ & black, compact residue, inside - only spots \\
\hline $27 \mathrm{MV}-1 \mathrm{~B}$ & 1 & Moverna vas 1988 & 6 & 050.1 & $5 / 6$ & black, compact residue on section \\
\hline $27 \mathrm{MV}-1 \mathrm{C}$ & 1 & Moverna vas 1988 & 6 & 050.1 & $5 / 6$ & black, compact residue outside - only spots \\
\hline $27 \mathrm{MV}-2$ & I & Moverna vas 1988 & 6 & 050.1 & $5 / 6$ & $\begin{array}{l}\text { foot of a pedestal dish with red slip, or- } \\
\text { ganic residue on the foot }\end{array}$ \\
\hline $28 \mathrm{MV}-1 \mathrm{~A}$ & 1 & Moverna vas 1988 & 5 & 050.2 & $5 / 10$ & black, compact residue, inside - only spots \\
\hline $28 \mathrm{MV}-1 \mathrm{~B}$ & 1 & Moverna vas 1988 & 5 & 050.2 & $5 / 10$ & black, compact residue on section \\
\hline $28 \mathrm{MV}-1 \mathrm{C}$ & 1 & Moverna vas 1988 & 5 & 050.2 & $5 / 10$ & black, compact residue outside - only spots \\
\hline $28 \mathrm{MV}-2$ & I & Moverna vas 1988 & 5 & 050.2 & $5 / 10$ & $\begin{array}{l}\text { foot of a pedestal dish with red slip, orga- } \\
\text { nic residue on the foot }\end{array}$ \\
\hline 29MV-1A & l & Moverna vas 1984 & 212 & $323-332 \mathrm{~cm}$ & 2/1-8/7, N-profile & $\begin{array}{l}\text { pale brown residue on various parts, mixed } \\
\text { with black residue - possibly soil, outside }\end{array}$ \\
\hline 29MV-1B & I & Moverna vas 1984 & 212 & $323-332 \mathrm{~cm}$ & $2 / 1-8 / 7, N$-profile & $\begin{array}{l}\text { "black, compact residue in form of a lump, } \\
\text { located just below the rim and running } \\
\text { over the rib; looks charred and visible } \\
\text { fibres, outside" }\end{array}$ \\
\hline 29MV-2 & I & Moverna vas 1984 & 212 & $323-332 \mathrm{~cm}$ & $2 / 1-8 / 7, \mathrm{~N}$-profile & $\begin{array}{l}\text { rim of a biconical cup, organic residue on } \\
\text { exterior }\end{array}$ \\
\hline $30 \mathrm{MV}-1$ & 1 & Moverna vas 1984 & 1 & 1 & $2 / 9 / 7, T 8-7 / 7$ & white, compact residue in spots, inside \\
\hline $30 \mathrm{MV}-2$ & l & Moverna vas 1984 & l & l & 2/9/7, T8-7/7 & $\begin{array}{l}\text { base of a miniature bottle with incised de- } \\
\text { coration, whiteish residue on interior }\end{array}$ \\
\hline $90 \mathrm{MV}$ & 1 & Moverna vas 1988 & R6 & 056.3 & $5 / 7$ & body of a spouted dish, type 1 \\
\hline ופMV & 2 & Moverna vas 1988 & $\mathrm{R} 17$ & 056 & $4 / 11$ & $\begin{array}{l}\text { body of spouted dish (two fragments), type } \\
\text { 1, burnt interior }\end{array}$ \\
\hline $92 \mathrm{MV}$ & 3 & Moverna vas 1988 & R 174 & 056.3 & $3 / 10-14$ & $\begin{array}{l}\text { rim with body of a spouted dish, type } 1, \\
\text { impressed and combed decoration }\end{array}$ \\
\hline $93 \mathrm{MV}$ & 4 & Moverna vas 1988 & $\mathrm{R} 176$ & 056.3 & $3 / 7$ & $\begin{array}{l}\text { body of a spouted dish, type } 1 \text {, appliqué } \\
\text { decoration on exterior }\end{array}$ \\
\hline $94 \mathrm{MV}$ & 5 & Moverna vas 1988 & R226 & 056.1 & $6 / 13$ & body of a spouted dish, type 1 \\
\hline $95 \mathrm{MV}$ & 6 & Moverna vas 1988 & $\mathrm{R} 467$ & 050.2 & $?$ & $\begin{array}{l}\text { body of a spouted dish, type } 1 \text {, horizontal } \\
\text { rib and combed decoration }\end{array}$ \\
\hline $96 \mathrm{MV}$ & 7 & Moverna vas 1988 & R8 & 056.2 & $3 / 13$ & $\begin{array}{l}\text { body of a bowl with red slip, traces of re- } \\
\text { sidue on exterior, type } 2\end{array}$ \\
\hline $97 \mathrm{MV}$ & 8 & Moverna vas 1988 & R19 & 056.2 & $4 / 3$ & body of a bowl (two fragments), type 2 \\
\hline $98 \mathrm{MV}$ & 9 & Moverna vas 1988 & R23 & 056.3 & $5 / 6$ & rim of a bowl (two fragments), type 2 \\
\hline $99 \mathrm{MV}$ & 10 & Moverna vas 1988 & $\mathrm{R} 27$ & 056.3 & $5 / 10$ & body of a bowl, type 2 \\
\hline 100MV & 11 & Moverna vas 1988 & $\mathrm{R}_{3} 6$ & 056.2 & $3 / 7$ & $\begin{array}{l}\text { rim with body of a bowl (three fragments), } \\
\text { type } 2\end{array}$ \\
\hline $101 \mathrm{MV}$ & 12 & Moverna vas 1988 & R179 & 056.2 & $3 / 5,9$ & body of a bowl, type 2 \\
\hline $102 \mathrm{MV}$ & $?$ & Moverna vas 1988 & $?$ & 056.3 & $3 / 7$ & rim of a bowl, type 2 \\
\hline $103 \mathrm{MV}$ & 13 & Moverna vas 1988 & $\mathrm{R} 2 \mathrm{O}$ & 056.3 & $4 / 13$ & body of a small pot with red slip, type 3 \\
\hline 104MV & 14 & Moverna vas 1988 & R239 & 056.3 & $5 / 13$ & body of a small pot (two fragments), type 3 \\
\hline $105 \mathrm{MV}$ & 15 & Moverna vas 1988 & sample 99 & $050.1-2$ & $3 / 7$ & $\begin{array}{l}\text { body of a small pot (three fragments), type } \\
\text { 3, horizontal rib }\end{array}$ \\
\hline
\end{tabular}




\begin{tabular}{|c|c|c|c|c|c|c|}
\hline $\begin{array}{l}\text { Sample } \\
\text { \# CHEM }\end{array}$ & $\begin{array}{r}\text { Sample } \\
\text { \# ARCH }\end{array}$ & Site code & SF \# & $\begin{array}{l}\text { SE/rel. } \\
\text { depth }\end{array}$ & $\begin{array}{c}\text { Sector/ } \\
\text { quadrant }\end{array}$ & Description \\
\hline $106 \mathrm{MV}$ & 16 & Moverna vas 1988 & sample 103 & 056.2 & $3 / 14$ & $\begin{array}{l}\text { body of a small pot (three fragments), type } 3 \text { hori- } \\
\text { zontal rib }\end{array}$ \\
\hline $107 \mathrm{MV}$ & 17 & Moverna vas 1988 & sample 104 & 056.2 & $3 / 9$ & body of a small pot with red slip, type 3 \\
\hline $108 \mathrm{MV}$ & 18 & Moverna vas 1988 & sample 105 & 056.2 & $3 / 3$ & base of a small pot with red slip, type 3 \\
\hline $109 \mathrm{MV}$ & 19 & Moverna vas 1988 & sample 106 & 056.2 & $3 / 3$ & body of a small pot, horizontal rib, type 3 \\
\hline $110 \mathrm{MV}$ & 20 & Moverna vas 1988 & sample 107 & 056.2 & $3 / 6$ & rim with body of a small pot with red slip, type 3 \\
\hline $111 \mathrm{MV}$ & 21 & Moverna vas 1988 & sample 108 & 056.2 & $3 / 6$ & base of a small pot with red slip, type 3 \\
\hline $112 \mathrm{MV}$ & 22 & Moverna vas 1988 & sample 109 & 056.2 & $3 / 8$ & rim of a small pot with red slip, type 3 \\
\hline $113 \mathrm{MV}$ & 23 & Moverna vas 1988 & sample 110 & 056.2 & $3 / 2$ & whole profile of a small pot with red slip, type 3 \\
\hline $114 \mathrm{MV}$ & 24 & Moverna vas 1988 & sample 111 & 056.2 & $3 / 2$ & base of a small pot, type 3 \\
\hline $115 \mathrm{MV}$ & 25 & Moverna vas 1988 & sample 112 & 056.2 & $3 / 7$ & body of a small pot with red slip, type 3 \\
\hline $116 \mathrm{MV}$ & 26 & Moverna vas 1988 & sample 113 & 056.2 & $3 / 1-16$ & body of a small pot with fragmented handle, type 3 \\
\hline $117 \mathrm{MV}$ & 27 & Moverna vas 1988 & sample 114 & 056.2 & $3 / 14$ & $\begin{array}{l}\text { body of a small pot with red slip (two fragments), } \\
\text { horizontal rib, type } 3\end{array}$ \\
\hline $118 \mathrm{MV}$ & 28 & Moverna vas 1988 & sample 115 & 056.2 & $3 / 14$ & body of a small pot with red slip, type 3 \\
\hline $119 \mathrm{MV}$ & 29 & Moverna vas 1988 & sample 116 & 056.2 & $3 / 14$ & $\begin{array}{l}\text { body of a small pot with red slip, horizontal rib, } \\
\text { type } 3\end{array}$ \\
\hline $120 \mathrm{MV}$ & 30 & Moverna vas 1988 & sample 117 & 056.2 & $3 / 14$ & body of a small pot with red slip, type 3 \\
\hline $121 \mathrm{MV}$ & 31 & Moverna vas 1988 & sample 118 & 056.2 & $3 / 14$ & $\begin{array}{l}\text { body of a small pot, incides decoration on in- } \\
\text { terior, type } 3\end{array}$ \\
\hline $122 \mathrm{MV}$ & 32 & Moverna vas 1988 & sample 119 & 056.2 & $?$ & rim and base of a small pot with grey slip, type 3 \\
\hline $123 \mathrm{MV}$ & 33 & Moverna vas 1988 & sample 120 & 056.2 & $3 / 15$ & body of a small pot with red slip, type 3 \\
\hline $124 \mathrm{MV}$ & 34 & Moverna vas 1988 & sample 121 & 056.2 & $3 / 5$ & body and base of a small pot with red slip, type 3 \\
\hline $125 \mathrm{MV}$ & 35 & Moverna vas 1988 & sample 132 & 056.3 & $5 / 5$ & body of a small pot, horizontal rib, type 3 \\
\hline $126 \mathrm{MV}$ & 36 & Moverna vas 1988 & sample 133 & 056.3 & $5 / 5$ & rim of a small pot with red slip, type 3 \\
\hline $127 \mathrm{MV}$ & 37 & Moverna vas 1988 & sample 134 & 056.3 & $5 / 10$ & body of a small pot with red slip, type 3 \\
\hline $128 \mathrm{MV}$ & 38 & Moverna vas 1988 & sample 183 & 056.2 & $4 / 7.3 / 3$ & body of a pot (two fragments), type 4 \\
\hline $129 \mathrm{MV}$ & 39 & Moverna vas 1988 & sample 225 & 056.3 & $3 / 12$ & body of a pot (two fragments), type 4 \\
\hline $130 \mathrm{MV}$ & 40 & Moverna vas 1988 & sample 102 & 056.3 & $5 / 11$ & body of a pot, type 5 , combed decoration on exterior \\
\hline $131 \mathrm{MV}-1$ & 41 & Moverna vas 1988 & sample 128 & 056.2 & $3 / 5$ & brown visible residue on exterior \\
\hline $131 \mathrm{MV}-2$ & 41 & Moverna vas 1988 & sample 128 & 056.2 & $3 / 5$ & $\begin{array}{l}\text { body of a pot, type } 5 \text {, horizontal rib and combed dec- } \\
\text { oration on exterior, organic residue on exterior }\end{array}$ \\
\hline $132 \mathrm{MV}$ & 42 & Moverna vas 1988 & $\mathrm{R}_{3} 8$ & 056.3 & $3 / 7$ & body of a pot, type 5 \\
\hline $133 \mathrm{MV}$ & 43 & Moverna vas 1988 & $\mathrm{R} 130$ & 056.2 & $3 / 3$ & rim of a pot, type 5 \\
\hline $134 \mathrm{MV}$ & 44 & Moverna vas 1988 & R131 & 056.2 & $3 / 3$ & $\begin{array}{l}\text { rim and body of a pot, type } 5 \text {, horizontal rib and } \\
\text { combed decoration on exterior }\end{array}$ \\
\hline $135 \mathrm{MV}$ & 45 & Moverna vas 1988 & $R_{181}$ & 056.3 & $5 / 1$ & $\begin{array}{l}\text { body of a pot (two fragments), type } 5 \text {, combed } \\
\text { decoration on exterior }\end{array}$ \\
\hline $136 \mathrm{MV}$ & 46 & Moverna vas 1984 & R222 & $1 / 8 / 7$ & $1 / 5-8$ & body of a pot, type 5 , incised decoration on exterior \\
\hline $137 \mathrm{MV}$ & 47 & Moverna vas 1984 & $\mathrm{R} 262$ & $2 / 5 / 7$ & $2 / 9$ & $\begin{array}{l}\text { body of a pot (two fragments), type } 5 \text {, impressed } \\
\text { and combed decoration on exterior }\end{array}$ \\
\hline $138 \mathrm{MV}$ & 48 & Moverna vas 1988 & R212 & 050.1 & $5 / 11$ & body of a pot (three fragments), type 6 \\
\hline 139MV & 49 & Moverna vas 1988 & sample 101 & 056.3 & $3 / 14$ & $\begin{array}{l}\text { body of a pot, type } 6 \text {, horizontal rib and combed } \\
\text { decoration on exterior }\end{array}$ \\
\hline 140MV & 50 & Moverna vas 1988 & R8 & 056.3 & $3 / 10$ & body of a pedestal dish with red slip, type 7 \\
\hline $141 \mathrm{MV}$ & 51 & Moverna vas 1988 & $\mathrm{R} 122$ & 056.2 & $3 / 2$ & rim of a pedestal dish with red slip, type 7 \\
\hline $142 \mathrm{MV}$ & 52 & Moverna vas 1988 & $\mathrm{R} 124$ & 056.2 & $3 / 11$ & base with foot of a pedestal dish, type 7 , red slip \\
\hline $143 \mathrm{MV}$ & 53 & Moverna vas 1988 & $\mathrm{R} 127$ & 056.2 & $3 / 5$ & rim and body of a pedestal dish, type 7 , red slip \\
\hline 144MV & 54 & Moverna vas 1988 & R224 & 056.3 & $3 / 5$ & base with foot of a pedestal dish, type 7 , red slip \\
\hline 145MV & 55 & Moverna vas 1988 & R264 & 050.1 .2 & $3 / 3$ & body of a pedestal dish, type 7 , red slip \\
\hline $146 \mathrm{MV}$ & 56 & Moverna vas 1984 & $\mathrm{R}_{5} 6$ & $1 / 8 / 7$ & $1 / 5-6$ & base and foot of a pedestal dish, type 7 , red slip \\
\hline 147MV & 57 & Moverna vas 1988 & sample 100 & 056.2 & $3 / 7$ & base and foot of a pedestal dish, type 7 , red slip \\
\hline $148 \mathrm{MV}$ & 58 & Moverna vas 1988 & sample 123 & 056.2 & $3 / 2$ & $\begin{array}{l}\text { rim and body of a pedestal dish (two fragments), } \\
\text { type } 7 \text {, red slip }\end{array}$ \\
\hline $149 \mathrm{MV}$ & 59 & Moverna vas 1988 & sample 125 & 056.2 & $3 / 10$ & $\begin{array}{l}\text { rim and body of a pedestal dish (two fragments), } \\
\text { type } 7 \text {, red slip }\end{array}$ \\
\hline $150 \mathrm{MV}$ & 60 & Moverna vas 1988 & sample 126 & 056.2 & $3 / 5$ & rim of a pedestal dish, type 7 , red slip \\
\hline $151 \mathrm{MV}-1$ & 61 & Moverna vas 1988 & sample 135 & 031.4 & $6 / 12$ & black, compact residue, inside \\
\hline
\end{tabular}


Neolithic and Eneolithic activities inferred from organic residue analysis of pottery from Mala Triglavca, Moverna vas and Ajdovska jama...

\begin{tabular}{|c|c|c|c|c|c|c|}
\hline $\begin{array}{l}\text { Sample } \\
\text { \# CHEM }\end{array}$ & $\begin{array}{l}\text { Sample } \\
\text { \# ARCH }\end{array}$ & Site code & SF \# & $\begin{array}{l}\text { SE/rel. } \\
\text { depth }\end{array}$ & $\begin{array}{l}\text { Sector/ } \\
\text { quadrant }\end{array}$ & Description \\
\hline $151 \mathrm{MV}-2$ & 61 & Moverna vas 1988 & sample 135 & 031.4 & $6 / 12$ & $\begin{array}{l}\text { body of a pedestal dish, type } 7 \text {, red slip, organic } \\
\text { residue on interior }\end{array}$ \\
\hline 152MV-1 & 62 & Moverna vas 1988 & sample 136 & 050.2 & $5 / 3$ & $\begin{array}{l}\text { black, compact visible residue, covering interior sur- } \\
\text { face uniformly }\end{array}$ \\
\hline $152 M V-2$ & 62 & Moverna vas 1988 & sample 136 & 050.2 & $5 / 3$ & $\begin{array}{l}\text { body of a pedestal dish, type } 7 \text {, red slip, organic } \\
\text { residue on interior }\end{array}$ \\
\hline $153 \mathrm{MV}$ & 63 & Moverna vas 1988 & $\mathrm{R} 232$ & $\mathrm{O} 22$ & $5 / 11$ & $\begin{array}{l}\text { body of a pot, horizontal rib and incised decoration, } \\
\text { type } 8\end{array}$ \\
\hline $154 \mathrm{MV}$ & 64 & Moverna vas 1984 & $\mathrm{R}_{115}$ & $1 / 8 / 7$ & $1 / 0-5$ & $\begin{array}{l}\text { body of a pot (two fragments), combed decoration, } \\
\text { type } 9\end{array}$ \\
\hline $155 \mathrm{MV}$ & 65 & Moverna vas 1988 & sample 129 & 056.2 & $3 / 5$ & rim of a ladle, type 10 \\
\hline
\end{tabular}


Lucija Šoberl, Milena Horvat, Andreja Žibrat Gašparič, Marko Sraka, Richard Evershed and Mihael Budja

App. 2. Summary of lipid residue analysis and their interpretations

\begin{tabular}{|c|c|c|c|c|c|c|c|}
\hline $\begin{array}{l}\text { Sample } \\
\text { \# CHEM }\end{array}$ & $\begin{array}{l}\text { Vessel } \\
\text { part }\end{array}$ & Biomarkers detected & $\begin{array}{c}\text { Lipid } \\
\text { concentration } \\
{\left[\mu \mathrm{g} \mathrm{g}^{-1}\right]}\end{array}$ & $\mathrm{P} / \mathrm{S}$ & $\begin{array}{c}\delta^{13} C_{16: 0} \\
{[\% \circ]}\end{array}$ & $\begin{array}{c}\delta^{13} C_{18: 0} \\
{[\% \circ]}\end{array}$ & Interpretation \\
\hline O1AJ & body & 1 & 2.38 & 1 & 1 & 1 & $\mathrm{n} / \mathrm{a}$ \\
\hline $\mathrm{O} 2 \mathrm{AJ}$ & body & $\begin{array}{l}\mathrm{FA}_{14}, \mathrm{FA}_{16}, \mathrm{FA} 17, \mathrm{FA} 18 \\
\mathrm{~K}_{29}-\mathrm{K}_{35}, \mathrm{~K}_{33}: 1, \mathrm{~K}_{35: 1}\end{array}$ & 198.63 & 1.19 & -25.26 & -27.88 & $\begin{array}{l}\text { mixed animal fat, plant residue, } \\
\text { cooking }\end{array}$ \\
\hline $\mathrm{O} \mathrm{A} \mathrm{AJ}$ & body & $\begin{array}{l}\mathrm{FA}_{14}, \mathrm{FA}_{16}, \mathrm{FA} 17, \mathrm{FA} 18 \\
\mathrm{FA}_{20} \mathrm{O}-\mathrm{FA} 28 ; \mathrm{OH}_{24}-\mathrm{OH}_{34} ; \\
\mathrm{A}_{27}-\mathrm{A}_{31} \text {, traces of } \mathrm{WE}\end{array}$ & 83.19 & 0.46 & -26.44 & -29.27 & $\begin{array}{l}\text { ruminant adipose fat, plant residue, } \\
\text { waxes }\end{array}$ \\
\hline $\mathrm{O} 4 \mathrm{Al}$ & body & $\begin{array}{l}F_{14}, F_{15}, F A_{16}, F A_{17} \\
F A_{18}, K_{27}-K_{35}\end{array}$ & 161.18 & 1.15 & -25.45 & -31.25 & ruminant dairy fat, cooking \\
\hline O5Al & body & 1 & 0 & & 1 & 1 & $\mathrm{n} / \mathrm{a}$ \\
\hline $06 \mathrm{AJ}$ & body & 1 & 11.86 & 1.35 & 1 & I & $\mathrm{n} / \mathrm{a}$ \\
\hline o7AJ & body & $\mathrm{FA}_{14}, \mathrm{FA}_{16}, \mathrm{FA}_{18}, \mathrm{OH}_{24}-\mathrm{OH}_{32}$ & 7.9 & 1.10 & 1 & 1 & plant residue \\
\hline $31 \mathrm{AJ}$ & body & 1 & 4.43 & & 1 & 1 & $\mathrm{n} / \mathrm{a}$ \\
\hline $32 \mathrm{AJ}$ & body & 1 & 0 & & 1 & 1 & $\mathrm{n} / \mathrm{a}$ \\
\hline $33 \mathrm{AJ}$ & body & 1 & 2.16 & & 1 & 1 & $\mathrm{n} / \mathrm{a}$ \\
\hline $34 \mathrm{AJ}$ & body & 1 & 0 & & 1 & 1 & $\mathrm{n} / \mathrm{a}$ \\
\hline $35 \mathrm{AJ}$ & base & $\begin{array}{l}\mathrm{FA}_{16}, \mathrm{~A}_{25}-\mathrm{A}_{31} ; \mathrm{OH}_{24}-\mathrm{OH}_{32}, \\
\text { traces of WE }\end{array}$ & 12.94 & & I & l & plant residue \\
\hline $36 \mathrm{AJ}$ & body & 1 & 2.66 & & 1 & 1 & $\mathrm{n} / \mathrm{a}$ \\
\hline $37 \mathrm{Al}$ & body & $\begin{array}{l}\mathrm{FA}_{16}, \mathrm{FA}_{22}-34 ; \mathrm{A}_{25}-\mathrm{A}_{33} ; \\
\mathrm{OH}_{22}-\mathrm{OH}_{34}, \mathrm{WE}\end{array}$ & 99.93 & 3.30 & l & l & plant residue, waxes \\
\hline $38 \mathrm{Al}$ & $\mathrm{rim}$ & 1 & 0 & & 1 & 1 & $n / a$ \\
\hline $39 \mathrm{Al}$ & $\mathrm{rim}$ & 1 & 2.73 & & 1 & 1 & $\mathrm{n} / \mathrm{a}$ \\
\hline $4 \circ \mathrm{AJ}$ & body & 1 & 3.97 & & 1 & 1 & $\mathrm{n} / \mathrm{a}$ \\
\hline $41 \mathrm{AJ}$ & $\mathrm{rim}$ & 1 & 2.79 & & 1 & 1 & $n / a$ \\
\hline $42 \mathrm{AJ}$ & rim & 1 & 3.89 & & 1 & 1 & $n / a$ \\
\hline $43 \mathrm{AJ}$ & $\mathrm{rim}$ & l & 0 & & 1 & 1 & $\mathrm{n} / \mathrm{a}$ \\
\hline $44 \mathrm{AJ}$ & body & $\begin{array}{l}\mathrm{FA}_{14}, \mathrm{FA}_{16} 6, \mathrm{FA} 17, \mathrm{FA} 18 \\
\mathrm{DAGs}, \mathrm{TAGs}_{\mathrm{s}}\end{array}$ & 80.45 & 0.59 & -25.71 & -28.99 & mixed ruminant fat \\
\hline $45 \mathrm{Al}$ & rim & I & 1.08 & & 1 & 1 & $\mathrm{n} / \mathrm{a}$ \\
\hline $46 \mathrm{AJ}$ & rim & I & 0 & & I & I & $\mathrm{n} / \mathrm{a}$ \\
\hline $47 \mathrm{AJ}$ & body & I & 4.03 & & 1 & 1 & $\mathrm{n} / \mathrm{a}$ \\
\hline $48 \mathrm{AJ}$ & body & $\mathrm{FA}_{14}, \mathrm{FA} 16, \mathrm{FA} 18: 1, \mathrm{FA} 18, \mathrm{FA} 20$ & 7.05 & 3.40 & -22.41 & -27.40 & ruminant dairy fat, plant residue \\
\hline $49 \mathrm{AJ}$ & $\mathrm{rim}$ & $\mathrm{FA}_{16}, \mathrm{FA}_{18}, \mathrm{FA} 2 \mathrm{O}$ & 48 & 2.32 & -25.91 & -24.88 & porcine fat \\
\hline $50 \mathrm{Al}$ & body & 1 & 5.15 & & 1 & 1 & $\mathrm{n} / \mathrm{a}$ \\
\hline $51 \mathrm{AJ}$ & body & 1 & 0 & & 1 & 1 & $\mathrm{n} / \mathrm{a}$ \\
\hline $52 \mathrm{Al}$ & body & 1 & 0 & & 1 & 1 & $n / a$ \\
\hline $53 \mathrm{AJ}$ & body & 1 & 4.16 & & 1 & 1 & $\mathrm{n} / \mathrm{a}$ \\
\hline $54 \mathrm{Al}$ & $\mathrm{rim}$ & 1 & 1.76 & & 1 & 1 & $\mathrm{n} / \mathrm{a}$ \\
\hline $55 \mathrm{Al}$ & body & 1 & 7.34 & & 1 & 1 & $\mathrm{n} / \mathrm{a}$ \\
\hline $56 \mathrm{Al}$ & body & 1 & 6.72 & & 1 & 1 & $\mathrm{n} / \mathrm{a}$ \\
\hline $57 \mathrm{Al}$ & base & $\begin{array}{l}\mathrm{A}_{25}-\mathrm{A}_{33}, \mathrm{OH}_{24}-\mathrm{OH}_{34} \\
\mathrm{FA}_{22}-\mathrm{FA}_{3} \mathrm{O}\end{array}$ & 267.04 & & l & l & plant residue, waxes \\
\hline $58 \mathrm{~A} /-1$ & body & 1 & 0 & & 1 & 1 & $\mathrm{n} / \mathrm{a}$ \\
\hline $58 \mathrm{~A} /-2$ & body & 1 & 0 & & 1 & 1 & $\mathrm{n} / \mathrm{a}$ \\
\hline $59 \mathrm{AJ}$ & body & 1 & 4.66 & & 1 & 1 & $\mathrm{n} / \mathrm{a}$ \\
\hline $6 \circ \mathrm{Al}$ & rim & $\mathrm{FA}_{14}, \mathrm{FA} 16, \mathrm{FA} 18$ & 21.96 & 2.27 & -23.25 & -28.47 & ruminant dairy fat, plant residue \\
\hline $61 \mathrm{Al}$ & rim & $\begin{array}{l}\mathrm{FA}_{16}, \mathrm{FA} 17, \mathrm{FA} 18, \mathrm{FA} 2 \mathrm{O} \\
\mathrm{MAGs}, \mathrm{DAGs}, \mathrm{TAGs}\end{array}$ & 47.46 & 0.65 & -25.15 & -29.05 & ruminant dairy fat \\
\hline $62 \mathrm{AJ}$ & body & $\begin{array}{l}\mathrm{FA}_{14}, \mathrm{FA}_{16}, \mathrm{FA} 17, \mathrm{FA} 18, \\
\mathrm{MAGs}_{2} \mathrm{~A}_{27}-\mathrm{A}_{33}, \\
\mathrm{OH}_{24}-\mathrm{OH}_{32}, \mathrm{DAGs}, \mathrm{WE}, \mathrm{TAGs}\end{array}$ & 73.65 & 1.09 & l & l & animal fat, waxes \\
\hline $63 \mathrm{AJ}$ & body & I & 0 & & 1 & 1 & $\mathrm{n} / \mathrm{a}$ \\
\hline $64 \mathrm{Al}$ & rim & $\mathrm{FA}_{16}, \mathrm{FA}_{18}$ & 9.36 & 1.85 & -23.29 & -24.24 & ruminant adipose fat \\
\hline $65 \mathrm{Al}$ & body & $\mathrm{FA}_{16} 6, \mathrm{FA} 18, \mathrm{DAGs}$, traces TAGs & 13.37 & 2.64 & 1 & 1 & mixed animal fat \\
\hline $66 \mathrm{AJ}$ & rim & 1 & 0 & & 1 & 1 & $\mathrm{n} / \mathrm{a}$ \\
\hline $67 \mathrm{Al}$ & base & 1 & 5.02 & & I & I & $\mathrm{n} / \mathrm{a}$ \\
\hline
\end{tabular}


Neolithic and Eneolithic activities inferred from organic residue analysis of pottery from Mala Triglavca, Moverna vas and Ajdovska jama...

\begin{tabular}{|c|c|c|c|c|c|c|c|}
\hline $\begin{array}{l}\text { Sample } \\
\text { \# CHEM }\end{array}$ & $\begin{array}{l}\text { Vessel } \\
\text { part }\end{array}$ & Biomarkers detected & $\begin{array}{l}\text { Lipid } \\
\text { oncentration } \\
{\left[\mu \mathrm{g} \mathrm{g}^{-1}\right]}\end{array}$ & $\begin{array}{l}\mathrm{P} / \mathrm{S} \\
\text { ratio }\end{array}$ & $\begin{array}{c}\delta^{13} C_{16: 0} \\
{[\% \circ]}\end{array}$ & $\begin{array}{c}\delta^{13} C_{18: 0} \\
{[\% \circ]}\end{array}$ & Interpretation \\
\hline $68 \mathrm{AJ}$ & body & $F_{116}, F A_{18: 1,} F A_{1} 8$, traces WE & 11.39 & 2.96 & -25.91 & -26.47 & porcine fat, plant residue \\
\hline $69 \mathrm{Al}$ & body & $\begin{array}{l}\mathrm{FA}_{14}, \mathrm{FA} 15, \mathrm{FA} 16, \mathrm{FA}_{17}, \mathrm{FA} 18, \mathrm{~A}_{25}-\mathrm{A}_{33}, \\
\mathrm{OH}_{24}-\mathrm{OH}_{32}, \mathrm{FA}_{22}-\mathrm{FA}_{32}, \mathrm{WE}, \mathrm{DWE}\end{array}$ & 557.13 & 2.20 & I & l & plant residue, waxes \\
\hline $70 \mathrm{Al}$ & body & $\begin{array}{l}\mathrm{FA}_{14}, \mathrm{FA} 16, \mathrm{FA} 18, \mathrm{~A}_{25}-\mathrm{A}_{33}, \mathrm{OH}_{24}-\mathrm{OH}_{34}, \\
\mathrm{FA}_{22}-\mathrm{FA}_{3} \mathrm{O}, \mathrm{WE} \text {, traces DWE }\end{array}$ & 75.66 & 1.85 & l & l & plant residue, waxes \\
\hline $71 \mathrm{AJ}$ & body & FA16, FA18:1, FA $18, \mathrm{OH}, \mathrm{DAGs}, \mathrm{TAGs}$ & 42.94 & 0.82 & -29.11 & -31.78 & $\begin{array}{l}\text { ruminant adipose fat, plant } \\
\text { residue }\end{array}$ \\
\hline $72 \mathrm{AJ}$ & body & $F_{1} 6, F_{1} 8, K_{29}-K_{35}, K_{33}: 1, K_{35}: 1$ & 47.37 & 0.80 & -27.59 & -30.08 & $\begin{array}{l}\text { mixed ruminant fat, plant } \\
\text { residue, cooking }\end{array}$ \\
\hline $73 \mathrm{Al}$ & body & I & 1.46 & & I & 1 & $n / a$ \\
\hline$\overline{74 \mathrm{AJ}}$ & body & I & o & & 1 & 1 & $n / a$ \\
\hline ०8MT & body & $\begin{array}{l}\text { FA14, FA15br, FA15, FA16, FA17br, FA17, } \\
\text { FA18:1, FA18, MAGs, DAGs, TAGs, traces of WE }\end{array}$ & E 173.35 & 0.99 & -26.51 & -29.91 & $\begin{array}{l}\text { ruminant dairy fat, plant } \\
\text { residue }\end{array}$ \\
\hline ogMT & body & traces of $F_{1} 6 \& \& A_{1} 8, K_{31}-K_{35}$ & 1.9 & & I & 1 & $n / a$ \\
\hline $11 \mathrm{MT}$ & body & traces of $F_{1} 16 \& F_{1} 8, K_{31}-K_{35}$ & 0.81 & & 1 & 1 & $\mathrm{n} / \mathrm{a}$ \\
\hline $12 \mathrm{MT}$ & body & 1 & 0.42 & & 1 & 1 & $\mathrm{n} / \mathrm{a}$ \\
\hline 13MT & rim & $\begin{array}{l}\text { FA16, FA18, MAGs, DAGs, TAGs, } \\
\text { traces of WE, A and OH }\end{array}$ & 11.56 & 0.63 & -26.68 & -28.85 & $\begin{array}{l}\text { ruminant adipose fat, plant } \\
\text { residue }\end{array}$ \\
\hline $14 \mathrm{MT}$ & body & 1 & 0.24 & & 1 & 1 & $\mathrm{n} / \mathrm{a}$ \\
\hline 15MT & body & I & o & & I & l & $n / a$ \\
\hline $16 \mathrm{MT}$ & body & 1 & 0 & & 1 & 1 & $\mathrm{n} / \mathrm{a}$ \\
\hline $17 \mathrm{MT}$ & body & 1 & 1.01 & & 1 & 1 & $\mathrm{n} / \mathrm{a}$ \\
\hline 18MT & body & 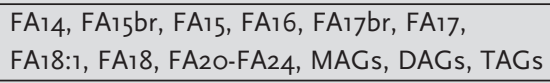 & is 88.09 & 0.75 & -27.68 & -33.26 & ruminant dairy fat \\
\hline 75MT & rim & $\begin{array}{l}\text { FA14, FA15, FA16:1, FA16, FA17, FA17br, } \\
\text { FA18:1, FA18, FA20, MAGs, DAGs, TAGs }\end{array}$ & 90.54 & 0.64 & -28.96 & -31.52 & ruminant adipose fat \\
\hline $76 \mathrm{MT}$ & base & 1 & 2.92 & & 1 & 1 & $\mathrm{n} / \mathrm{a}$ \\
\hline $77 \mathrm{MT}$ & body & 1 & 0 & & 1 & 1 & $\mathrm{n} / \mathrm{a}$ \\
\hline $78 \mathrm{MT}$ & body & 1 & 2.58 & & 1 & 1 & $\mathrm{n} / \mathrm{a}$ \\
\hline $79 \mathrm{MT}$ & body & $\begin{array}{l}\text { FA14, FA16, FA17, FA18:1, FA18, FA2O, } \\
\text { traces of A \& OH, DAGs, TAGs }\end{array}$ & 27.23 & 1.24 & -27.80 & -32.91 & $\begin{array}{l}\text { ruminant dairy fat, plant } \\
\text { residue }\end{array}$ \\
\hline $80 \mathrm{MT}$ & rim & 1 & 3.45 & & 1 & 1 & $\mathrm{n} / \mathrm{a}$ \\
\hline $81 \mathrm{MT}$ & body & 1 & 1.34 & & 1 & 1 & $n / a$ \\
\hline $82 \mathrm{MT}$ & base & 1 & 0 & & 1 & 1 & $\mathrm{n} / \mathrm{a}$ \\
\hline $83 \mathrm{MT}$ & body & 1 & 3.12 & & 1 & 1 & $n / a$ \\
\hline $84 \mathrm{MT}$ & base & 1 & 1.1 & & 1 & 1 & $\mathrm{n} / \mathrm{a}$ \\
\hline $85 \mathrm{MT}$ & $\mathrm{rim}$ & 1 & 1.34 & & 1 & 1 & $n / a$ \\
\hline $86 \mathrm{MT}$ & rim & 1 & 1.38 & & 1 & I & $n / a$ \\
\hline $87 \mathrm{MT}$ & body & 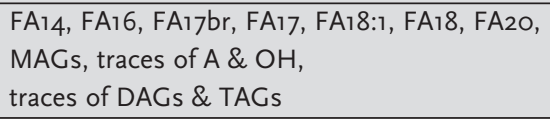 & 21.93 & 1.05 & -27.35 & -32.18 & $\begin{array}{l}\text { ruminant dairy fat, plant } \\
\text { residue }\end{array}$ \\
\hline $88 \mathrm{MT}$ & rim & $\mathrm{FA}_{14}, \mathrm{FA}_{16}, \mathrm{FA} 18, \mathrm{FA} 2 \mathrm{O}$ & 9.93 & 2.56 & -26.97 & -31.91 & ruminant dairy fat \\
\hline $89 \mathrm{MT}$ & rim & 1 & 0 & & 1 & 1 & $\mathrm{n} / \mathrm{a}$ \\
\hline $156 \mathrm{MT}$ & rim & 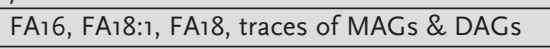 & 10.06 & 2.27 & 1 & 1 & $\mathrm{n} / \mathrm{a}$ \\
\hline $157 \mathrm{MT}$ & rim & 1 & 4.06 & & 1 & 1 & $\mathrm{n} / \mathrm{a}$ \\
\hline $158 \mathrm{MT}$ & rim & 1 & 0.98 & & 1 & 1 & $\mathrm{n} / \mathrm{a}$ \\
\hline $159 \mathrm{MT}$ & rim & FA16, FA18, MAGs, DAGs, TAGs & 12.65 & 1.32 & 1 & 1 & mixed animal fat \\
\hline $160 \mathrm{MT}$ & complete & FA16, FA18, traces of MAGs, DAGs \& TAGs & 5.53 & 3.46 & 1 & 1 & $\mathrm{n} / \mathrm{a}$ \\
\hline $161 \mathrm{MT}$ & rim & FA16, FA18:1, FA18, MAGs, traces of DAGs & 43.81 & 1.11 & -29.38 & -33.95 & ruminant dairy fat \\
\hline $162 \mathrm{MT}$ & $\mathrm{n} / \mathrm{a}$ & 1 & 2.77 & & 1 & 1 & $\mathrm{n} / \mathrm{a}$ \\
\hline $163 \mathrm{MT}$ & body & $\mathrm{FA} 16, \mathrm{FA} 18$ & 4.02 & & 1 & 1 & $\mathrm{n} / \mathrm{a}$ \\
\hline $164 \mathrm{MT}$ & $\mathrm{rim}$ & $\mathrm{FA}_{16}, \mathrm{FA} 18$ & 2.47 & & 1 & 1 & $\mathrm{n} / \mathrm{a}$ \\
\hline $165 \mathrm{MT}$ & rim & 1 & 1.53 & & 1 & 1 & $\mathrm{n} / \mathrm{a}$ \\
\hline $166 \mathrm{MT}$ & rim & 1 & 4.67 & & 1 & 1 & $\mathrm{n} / \mathrm{a}$ \\
\hline $23 \mathrm{MV}-1$ & rim & $\mathrm{FA}_{16} 6, \mathrm{FA}_{18} 8$, traces $\mathrm{OH}$ & 361.4 & 0.30 & 1 & 1 & animal fat \\
\hline $23 \mathrm{MV}-2$ & rim & $\begin{array}{l}\mathrm{FA}_{14}, \mathrm{FA} 16, \mathrm{FA} 17 \mathrm{br}, \mathrm{FA} 17, \mathrm{FA} 18, \mathrm{FA} 2 \mathrm{O} \\
\mathrm{OH}_{24}-\mathrm{OH}_{34}, \mathrm{~A}_{29}-\mathrm{A}_{35}, \mathrm{WE}\end{array}$ & 434.99 & 0.25 & -26.99 & -30.46 & mixed fat, waxes \\
\hline $24 \mathrm{MV}-1$ & base & pitch markers & 1789.97 & & I & I & birch bark tar \\
\hline
\end{tabular}


Lucija Šoberl, Milena Horvat, Andreja Žibrat Gašparič, Marko Sraka, Richard Evershed and Mihael Budja

\begin{tabular}{|c|c|c|c|c|c|c|c|}
\hline $\begin{array}{l}\text { Sample } \\
\text { \# CHEM }\end{array}$ & $\begin{array}{c}\text { Vessel } \\
\text { part }\end{array}$ & Biomarkers detected & $\begin{array}{c}\text { Lipid } \\
\text { concentration } \\
{\left[\mu \mathrm{g} \mathrm{g}^{-1}\right]}\end{array}$ & $\begin{array}{l}\mathrm{P} / \mathrm{S} \\
\text { ratio }\end{array}$ & $\begin{array}{c}\delta^{13} C_{16: 0} \\
{[\% \circ]}\end{array}$ & $\begin{array}{c}\delta^{13} \mathrm{C}_{18: \circ} \\
{[\% \circ]}\end{array}$ & Interpretation \\
\hline $24 \mathrm{MV}-2$ & base & traces of pitch markers & 0.77 & & 1 & 1 & $n / a$ \\
\hline $25 \mathrm{MV}-1 \mathrm{~A}$ & base & pitch markers, traces of WE & 720.94 & & 1 & 1 & birch bark tar, waxes \\
\hline $25 \mathrm{MV}-1 \mathrm{~B}$ & base & pitch markers, traces of WE & 911.02 & & 1 & 1 & birch bark tar, waxes \\
\hline $25 \mathrm{MV}-2$ & base & pitch markers, traces of WE & 31.06 & & I & I & birch bark tar, waxes \\
\hline $26 \mathrm{MV}-1$ & base & pitch markers & 1539.77 & & 1 & 1 & birch bark tar \\
\hline $26 \mathrm{MV}-2$ & base & FA10, FA12, FA14, FA16, FA18, pitch markers, WE & E $\quad 24.3$ & 1.48 & 1 & I & birch bark tar, waxes \\
\hline $27 \mathrm{MV}-1 \mathrm{~A}$ & base & FA16, FA18, pitch markers & 3308.1 & 1.33 & 1 & 1 & birch bark tar \\
\hline $27 \mathrm{MV}-1 \mathrm{~B}$ & base & $\mathrm{FA}_{16} 6, \mathrm{FA} 18$, pitch markers & 118.18 & 1.34 & 1 & I & birch bark tar \\
\hline $27 \mathrm{MV}-1 \mathrm{C}$ & base & $\mathrm{FA}_{16} 6, \mathrm{FA}_{17}, \mathrm{FA}_{18: 1,} \mathrm{FA}_{18}$, pitch markers & 740.32 & 1.71 & 1 & 1 & birch bark tar, plant residue \\
\hline $27 \mathrm{MV}-2$ & base & 1 & 0 & & I & I & $\mathrm{n} / \mathrm{a}$ \\
\hline 28MV-1A & base & $\mathrm{FA}_{16} 6, \mathrm{FA}_{1} 8$, pitch markers, WE & 3056.3 & 1.32 & l & l & $\begin{array}{l}\text { birch bark tar, plant resi- } \\
\text { due, waxes }\end{array}$ \\
\hline 28MV-1B & base & $\mathrm{FA}_{1} 6, \mathrm{FA}_{1} 8$, pitch markers, WE & 542.58 & 1.30 & l & l & $\begin{array}{l}\text { birch bark tar, plant resi- } \\
\text { due, waxes }\end{array}$ \\
\hline 28MV-1C & base & $\mathrm{FA}_{1} 6, \mathrm{FA}_{1} 8$, pitch markers, WE & 1261.79 & 1.68 & l & l & $\begin{array}{l}\text { birch bark tar, plant resi- } \\
\text { due, waxes }\end{array}$ \\
\hline $28 \mathrm{MV}-2$ & base & $\mathrm{FA} 16, \mathrm{~A}, \mathrm{OH}$, traces of WE & 5.25 & & 1 & 1 & plant residue \\
\hline $29 M V-1 A$ & rim & I & 18.03 & & 1 & I & $\mathrm{n} / \mathrm{a}$ \\
\hline $29 M V-1 B$ & rim & $F_{16} 6: 1, F A_{16}, F A_{18: 1,} F A_{18}$ & 8.06 & 1.89 & 1 & I & plant residue \\
\hline 29MV-2 & rim & $\begin{array}{l}F A_{14}, F A_{16}: 1, F A_{16} 6, F A_{17}, F A_{18: 1,} F A_{18}, \\
F A_{20}-F_{24}, K_{31}-K_{35}\end{array}$ & 27.57 & 1.02 & I & I & $\begin{array}{l}\text { mixed animal and plant } \\
\text { residue, cooking }\end{array}$ \\
\hline 30MV-1 & base & l & 0 & & 1 & 1 & $\mathrm{n} / \mathrm{a}$ \\
\hline $30 \mathrm{MV}-2$ & base & $\mathrm{FA}_{16}, \mathrm{MAG}_{16}, \mathrm{DAG}_{32}, \mathrm{TAG}_{54}$ & 17.69 & & I & I & plant residue \\
\hline $90 \mathrm{MV}$ & body & / & 0 & & 1 & 1 & $\mathrm{n} / \mathrm{a}$ \\
\hline $91 \mathrm{MV}$ & body & $F_{116}, F_{17}, F_{18} 8-F_{24}, K_{29}-K_{35}$ & 156.62 & 0.31 & -27.53 & -31.65 & ruminant dairy fat, cooking \\
\hline $92 \mathrm{MV}$ & rim & $\begin{array}{l}\text { FA14, FA16, FA18, FA2O, MAGs, } \\
\text { traces of DAGs and TAGs }\end{array}$ & 29.41 & 1.02 & -27.75 & -30.35 & mixed ruminant fat \\
\hline $93 \mathrm{MV}$ & body & $\begin{array}{l}\text { FA14, FA16, FA17, FA18:1, FA18, } \\
\text { MAGs, DAGs, TAGs }\end{array}$ & 119.17 & 0.77 & -27.92 & -31.36 & mixed ruminant fat \\
\hline $94 \mathrm{MV}$ & body & $\mathrm{FA}_{16} 6, \mathrm{FA}_{18}, \mathrm{FA}_{20}$ & 15.2 & 0.57 & -28.41 & -30.89 & ruminant adipose fat \\
\hline $95 \mathrm{MV}$ & body & $\mathrm{FA}_{1} 6, \mathrm{FA} 18, \mathrm{MAGs}$, traces of DAGs and TAGs & 5.5 & 1.19 & -26.65 & -28.90 & mixed animal fat \\
\hline $96 \mathrm{MV}$ & body & $\mathrm{FA}_{14}, \mathrm{FA} 16, \mathrm{FA} 18, \mathrm{FA} 20, \mathrm{MAGs}, \mathrm{DAGs}, \mathrm{TAGs}$ & 9.51 & 0.81 & -27.18 & -31.09 & dairy fat \\
\hline $97 \mathrm{MV}$ & body & $\mathrm{FA}_{16} 6, \mathrm{FA} 18$ & 10.52 & 0.92 & I & I & mixed animal fat \\
\hline $98 \mathrm{MV}$ & rim & $\begin{array}{l}\mathrm{FA}_{12}, \mathrm{FA} 14, \mathrm{FA} 16, \mathrm{FA} 17 \mathrm{br}, \mathrm{FA} 17, \mathrm{FA} 18, \\
\text { MAGs, traces of } A \text { \& OH, DAGs, } \\
\text { traces of WE, TAGs }\end{array}$ & 57.85 & 0.69 & -28.62 & -30.75 & $\begin{array}{l}\text { ruminant adipose fat, } \\
\text { plant residue, waxes }\end{array}$ \\
\hline $99 \mathrm{MV}$ & body & $\begin{array}{l}\mathrm{FA}_{16} 6, \mathrm{FA}_{1} 8, \mathrm{~A}_{25}-\mathrm{A}_{33}, \mathrm{OH}_{24}-\mathrm{OH}_{34} \\
\mathrm{FA}_{24}-\mathrm{FA}_{32}, \mathrm{WE}, \mathrm{DWE}\end{array}$ & 429.65 & 6.20 & -26.09 & -29.62 & $\begin{array}{l}\text { dairy fat, plant residue, } \\
\text { waxes }\end{array}$ \\
\hline 100MV & rim & $\begin{array}{l}\text { FA16, FA } 18, A_{25}-A_{31}, M A G s, \mathrm{OH}_{24}-\mathrm{OH}_{34} \text {, } \\
\text { DAGs, WE, DWE }\end{array}$ & 449.81 & 0.57 & -27.47 & -29.44 & $\begin{array}{l}\text { ruminant adipose fat, } \\
\text { waxes }\end{array}$ \\
\hline $101 \mathrm{MV}$ & body & 1 & o & & 1 & 1 & $\mathrm{n} / \mathrm{a}$ \\
\hline $102 \mathrm{MV}$ & rim & $\begin{array}{l}\text { traces of } \mathrm{FA}_{1} 6 \text { \& } \mathrm{FA}_{1} 8, \mathrm{~A}_{25}-\mathrm{A}_{33}, \\
\mathrm{OH}_{24}-\mathrm{OH}_{34}, \mathrm{FA}_{24}-\mathrm{FA} 34, \mathrm{WE}, \mathrm{DWE}\end{array}$ & 399.78 & 2.86 & -26.20 & -33.48 & plant residue, waxes \\
\hline $103 \mathrm{MV}$ & body & $\begin{array}{l}\text { FA16, FA18, MAGs, traces of A\&OH, } \\
\text { DAGs, traces of WE }\end{array}$ & 4.27 & & l & I & plant residue \\
\hline $104 \mathrm{MV}$ & body & $\mathrm{FA}_{14}, \mathrm{FA} 16, \mathrm{FA}_{17}, \mathrm{FA} 18$ & 214.36 & 0.65 & -27.66 & -30.22 & ruminant adipose fat \\
\hline $105 \mathrm{MV}$ & body & I & 0 & & 1 & 1 & $\mathrm{n} / \mathrm{a}$ \\
\hline $106 \mathrm{MV}$ & body & $\mathrm{FA}_{16} 6, \mathrm{FA}_{1} 8$, traces of $\mathrm{A} \& \mathrm{OH}$ & 4.51 & 2.15 & 1 & I & plant residue \\
\hline $107 \mathrm{MV}$ & body & $\mathrm{FA}_{16} 6, \mathrm{FA} 18$ & 29.38 & 0.67 & -26.68 & -28.39 & mixed animal fat \\
\hline $108 \mathrm{MV}$ & base & I & $\circ$ & & 1 & 1 & $\mathrm{n} / \mathrm{a}$ \\
\hline 109MV & body & $\mathrm{FA}_{16} 6, \mathrm{FA}_{17}, \mathrm{FA}_{18}$ & 126.6 & 0.90 & -26.14 & -26.19 & porcine fat \\
\hline $110 \mathrm{MV}$ & $\mathrm{rim}$ & $\mathrm{FA}_{16}, \mathrm{DA}_{17}, \mathrm{FA}_{18: 1,} \mathrm{FA}_{18}$, FA2O & 1219.85 & 1.17 & -24.90 & -24.96 & porcine fat \\
\hline $111 \mathrm{MV}$ & base & $\begin{array}{l}\mathrm{FA}_{12}, \mathrm{FA} 14, \mathrm{FA} 16, \mathrm{FA} 17, \mathrm{FA} 18: 1, \mathrm{FA} 18, \\
\mathrm{MAG}_{16}, \mathrm{~A}_{27}-\mathrm{A}_{33}, \mathrm{OH}_{24}-\mathrm{OH}_{34}, \mathrm{FA}_{24}-\mathrm{FA} 28, \mathrm{WE}\end{array}$ & E 177.63 & 2.47 & -25.40 & -25.73 & $\begin{array}{l}\text { porcine fat, plant residue, } \\
\text { waxes }\end{array}$ \\
\hline $112 \mathrm{MV}$ & rim & traces of $A \& O H$, traces of DAGs, WE & 5.22 & & I & 1 & plant residue \\
\hline $113 \mathrm{MV}$ & rim & $\begin{array}{l}\text { traces of } \mathrm{FA}_{1} 6 \text { \& } \mathrm{FA}_{1} 8, \mathrm{~A}_{23}-\mathrm{A}_{33}, \\
\mathrm{OH}_{24}-\mathrm{OH}_{34}, \mathrm{WE}\end{array}$ & 47.2 & & -26.36 & -27.85 & plant residue, waxes \\
\hline $114 \mathrm{MV}$ & base & $\begin{array}{l}\mathrm{FA}_{16} 6, \mathrm{FA}_{18}, \mathrm{~A}_{23}-\mathrm{A}_{33}, \mathrm{OH}_{22}-\mathrm{OH}_{34}, \\
\mathrm{FA}_{24}-\mathrm{FA} \mathrm{A}_{3} \mathrm{O}, \mathrm{WE}\end{array}$ & 94.85 & 2.89 & l & l & plant residue, waxes \\
\hline
\end{tabular}


Neolithic and Eneolithic activities inferred from organic residue analysis of pottery from Mala Triglavca, Moverna vas and Ajdovska jama...

\begin{tabular}{|c|c|c|c|c|c|c|c|}
\hline $\begin{array}{l}\text { Sample } \\
\text { \# CHEM }\end{array}$ & $\begin{array}{l}\text { Vessel } \\
\text { part }\end{array}$ & Biomarkers detected & $\begin{array}{l}\text { Lipid } \\
\text { concentration } \\
{\left[\mu \mathrm{g} \mathrm{g}^{-1]}\right.}\end{array}$ & $\begin{array}{l}\mathrm{P} / \mathrm{S} \\
\text { ratio }\end{array}$ & $\begin{array}{c}\delta^{13} C_{16: 0} \\
{[\% \circ]}\end{array}$ & $\begin{array}{c}\delta^{13} C_{18: \circ} \\
{[\% \circ]}\end{array}$ & Interpretation \\
\hline $115 \mathrm{MV}$ & body & 1 & 0 & & 1 & 1 & $\mathrm{n} / \mathrm{a}$ \\
\hline $116 \mathrm{MV}$ & body & $\mathrm{FA}_{16}, \mathrm{FA}_{18}, \mathrm{~A}_{23}-\mathrm{A}_{33}, \mathrm{OH}_{22}-\mathrm{OH}_{34}, \mathrm{FA} 26, \mathrm{WE}$ & $\begin{array}{ll}\text { E } & 145.68\end{array}$ & 3.24 & -26.68 & -28.75 & plant residue, waxes \\
\hline $117 \mathrm{MV}$ & body & 1 & 0 & & 1 & 1 & $\mathrm{n} / \mathrm{a}$ \\
\hline $118 \mathrm{MV}$ & body & 1 & 0 & & 1 & 1 & $\mathrm{n} / \mathrm{a}$ \\
\hline $119 \mathrm{MV}$ & body & 1 & o & & 1 & I & $n / a$ \\
\hline $120 \mathrm{MV}$ & body & $\mathrm{FA}_{16} 6, \mathrm{FA}_{17}, \mathrm{FA} 18: 1, \mathrm{FA} 18, \mathrm{FA} 20$ & 197.58 & 0.81 & -25.18 & -25.15 & porcine fat \\
\hline $121 \mathrm{MV}$ & body & $\mathrm{A}_{25}-\mathrm{A}_{33}, \mathrm{OH}_{24}-\mathrm{OH}_{34}, \mathrm{FA}_{24}-\mathrm{FA}_{32}, \mathrm{WE}$ & 970.81 & & -26.89 & -26.03 & $\begin{array}{l}\text { porcine fat, plant residue, } \\
\text { waxes }\end{array}$ \\
\hline $122 \mathrm{MV}$ & body & traces of $F A_{1} 6 \& F A_{1} 8$ & 2.18 & & 1 & 1 & $\mathrm{n} / \mathrm{a}$ \\
\hline $123 \mathrm{MV}$ & body & 1 & 0 & & 1 & l & $n / a$ \\
\hline $124 \mathrm{MV}$ & body & 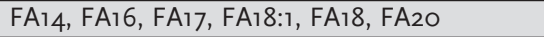 & 503.45 & 1.65 & -24.24 & -23.99 & porcine fat \\
\hline $125 \mathrm{MV}$ & body & $\mathrm{A}_{23}-\mathrm{A}_{31}, \mathrm{OH}_{24}-\mathrm{OH}_{32}$, traces of WE & 12.57 & & 1 & 1 & waxes \\
\hline $126 \mathrm{MV}$ & rim & traces of $\mathrm{A \& OH}$ & 1.4 & & 1 & 1 & $\mathrm{n} / \mathrm{a}$ \\
\hline $127 \mathrm{MV}$ & body & traces of $\mathrm{A} \& \mathrm{OH}$ & 1.74 & & 1 & 1 & $\mathrm{n} / \mathrm{a}$ \\
\hline $128 \mathrm{MV}$ & body & 1 & 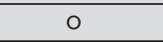 & & 1 & 1 & $\mathrm{n} / \mathrm{a}$ \\
\hline $129 \mathrm{MV}$ & body & I & 1.07 & & 1 & 1 & $n / a$ \\
\hline 130MV & body & l & 0 & & 1 & l & $\mathrm{n} / \mathrm{a}$ \\
\hline $131 \mathrm{MV}-1$ & body & 1 & 0 & & 1 & 1 & $\mathrm{n} / \mathrm{a}$ \\
\hline $131 \mathrm{MV}-2$ & body & 1 & o & & 1 & I & $\mathrm{n} / \mathrm{a}$ \\
\hline $132 \mathrm{MV}$ & body & $F_{1} 6, F_{17}, F_{1} 8$ & 13.45 & 0.60 & -26.57 & -29.84 & mixed ruminant fat \\
\hline $133 \mathrm{MV}$ & rim & $\mathrm{FA}_{14}, \mathrm{FA}_{16}, \mathrm{FA} 17 \mathrm{br}, \mathrm{FA} 17, \mathrm{FA} 18, \mathrm{~K}$ & 17.61 & 0.88 & 1 & 1 & mixed animal fat, cooking \\
\hline $134 \mathrm{MV}$ & rim & $\begin{array}{l}\mathrm{FA}_{14}, \mathrm{FA} 16, \mathrm{FA} 17 \mathrm{br}, \mathrm{FA} 17, \mathrm{FA} 18, \mathrm{MAGs}, \\
\mathrm{OH}_{22}-\mathrm{OH}_{32}, \mathrm{~A}_{29}-\mathrm{A}_{31}, \mathrm{DAGs}, \mathrm{WE}, \mathrm{TAGs}\end{array}$ & 289.58 & 0.54 & -28.35 & -29.94 & $\begin{array}{l}\text { ruminant adipose fat, } \\
\text { plant residue, waxes }\end{array}$ \\
\hline $135 \mathrm{MV}$ & body & $\begin{array}{l}\text { FA16, FA17, FA18, MAGs, } \\
\text { traces of DAGs \& TAGs }\end{array}$ & 47.71 & 1.41 & -27.47 & -26.99 & porcine fat \\
\hline $136 \mathrm{MV}$ & body & 1 & 1.06 & & 1 & 1 & $\mathrm{n} / \mathrm{a}$ \\
\hline $137 \mathrm{MV}$ & body & $\mathrm{FA}_{14}, \mathrm{FA} 16, \mathrm{FA} 18$ & 14.27 & 0.46 & -28.64 & -31.15 & ruminant adipose fat \\
\hline $138 \mathrm{MV}$ & body & 1 & o & & 1 & 1 & $\mathrm{n} / \mathrm{a}$ \\
\hline $139 \mathrm{MV}$ & body & 1 & o & & 1 & 1 & $\mathrm{n} / \mathrm{a}$ \\
\hline $140 \mathrm{MV}$ & body & $\begin{array}{l}\text { FA16, FA18, traces of } A \& O H ; \\
\text { traces of DAGs\&WE }\end{array}$ & 4.14 & 1.12 & l & I & mixed residue \\
\hline $141 \mathrm{MV}$ & rim & 1 & 0 & & I & 1 & $\mathrm{n} / \mathrm{a}$ \\
\hline $142 \mathrm{MV}$ & base & 1 & 0 & & 1 & 1 & $n / a$ \\
\hline $143 \mathrm{MV}$ & rim & $\begin{array}{l}\text { FA16, FA18, MAGs, } \mathrm{OH}_{22}-\mathrm{OH}_{32}, \mathrm{~A}_{27}-\mathrm{A}_{33}, \\
\text { DAGs, TAGs }\end{array}$ & 6.17 & 0.91 & -27.66 & -30.71 & $\begin{array}{l}\text { ruminant adipose fat, } \\
\text { plant residue }\end{array}$ \\
\hline 144MV & base & $\mathrm{FA}_{16} 6, \mathrm{FA}_{18}, \mathrm{FA}_{20}$ & 9.76 & 1.45 & -26.38 & -29.28 & ruminant adipose fat \\
\hline $145 \mathrm{MV}$ & body & $\begin{array}{l}\text { traces of } \mathrm{FA}_{1} 6 \& \mathrm{FA}_{1} 8, \mathrm{~A}_{27}-\mathrm{A}_{31}, \mathrm{OH}_{22}-\mathrm{OH}_{32}, \\
\text { traces of DAGs, WE \& TAGs }\end{array}$ & 6.82 & & l & l & mixed residue \\
\hline $146 \mathrm{MV}$ & base & 1 & 0 & & 1 & 1 & $\mathrm{n} / \mathrm{a}$ \\
\hline $147 \mathrm{MV}$ & base & $\begin{array}{l}F A_{12}, F A_{14}, F A_{15}, F A_{16}, F A_{17}, F A_{18}: 1, F A_{18}, \\
F A_{20}-F A_{3} O, M A G s, A_{25}-A_{33}, O_{22}-O_{32} \\
\text { DAGs, WE }\end{array}$ & 37.61 & 0.53 & I & l & $\begin{array}{l}\text { mixed animal and plant } \\
\text { residue, waxes }\end{array}$ \\
\hline $148 \mathrm{MV}$ & rim & 1 & $\circ$ & & 1 & 1 & $\mathrm{n} / \mathrm{a}$ \\
\hline $149 \mathrm{MV}$ & rim & $\begin{array}{l}\mathrm{FA}_{14}, \mathrm{FA}_{16} 6, \mathrm{FA}_{17} \mathrm{br}_{1} \mathrm{FA}_{17}, \mathrm{FA} 18, \mathrm{FA} 2 \mathrm{O}-\mathrm{FA} 26 \\
\text { MAGs, } \mathrm{A}_{23}-\mathrm{A}_{33}, \mathrm{OH}_{22}-\mathrm{OH}_{32}, \mathrm{DAG} \text {, } \\
\text { traces of TAGs }\end{array}$ & 20.49 & 0.76 & -26.71 & -29.22 & $\begin{array}{l}\text { ruminant adipose fat, } \\
\text { plant residue }\end{array}$ \\
\hline $150 \mathrm{MV}$ & rim & $\begin{array}{l}\mathrm{FA}_{16} 6, \mathrm{FA} 17, \mathrm{FA} 18, \mathrm{MAGs}, \mathrm{A}_{27}-\mathrm{A}_{33}, \\
\mathrm{OH}_{24}-\mathrm{OH}_{32}, \mathrm{DAGs} \text {, traces of TAGs }\end{array}$ & 9.63 & 0.73 & -27.42 & -30.82 & $\begin{array}{l}\text { ruminant fat, plant } \\
\text { residue }\end{array}$ \\
\hline $151 \mathrm{MV}-1$ & body & traces of $F_{1} 6 \& F_{1} 8$, pitch markers & 2918.51 & & 1 & 1 & birch bark tar \\
\hline $151 \mathrm{MV}-2$ & body & $F_{16} 6, A_{18}$, pitch markers & 91.85 & 0.44 & 1 & 1 & animal fat, birch bark tar \\
\hline 152MV-1 & body & $\begin{array}{l}\text { traces of } F A_{1} 6 \& F_{1} 8 \text {, pitch markers, } \\
\text { traces of TAGs }\end{array}$ & 2818.76 & 0.91 & I & l & $\begin{array}{l}\text { mixed animal fat, birch } \\
\text { bark tar }\end{array}$ \\
\hline $152 \mathrm{MV}-2$ & body & 1 & 0 & & 1 & 1 & $\mathrm{n} / \mathrm{a}$ \\
\hline $153 \mathrm{MV}$ & body & $\begin{array}{l}F_{14} 4, F A_{15}, F A_{16} 6, F A_{17} b_{r}, F A_{17}, F A_{18: 1,} \\
F A_{18}, F A_{20} \text {, MAs, DAGs, traces of TAGs }\end{array}$ & 55.01 & 0.76 & -27.70 & -29.97 & ruminant adipose fat \\
\hline $154 \mathrm{MV}$ & body & $\begin{array}{l}F_{14}, F_{15} b_{r}, F_{15}, F A_{16}, F A_{17} b_{r}, F A_{17}, \\
F_{18}, F_{20}-F_{28}, M A G s, A_{23}-A_{33}, \\
\mathrm{OH}_{22}-\mathrm{OH}_{32} \text {, traces of DAGs \& TAGs, WE }\end{array}$ & 607.11 & 0.29 & -27.96 & -31.10 & $\begin{array}{l}\text { ruminant fat, plant resi- } \\
\text { due, waxes }\end{array}$ \\
\hline $155 \mathrm{MV}$ & rim & $\begin{array}{l}\text { FA14, FA16, FA17, FA18:1, FA18, } \\
\text { traces of DAGs \& TAGs }\end{array}$ & 7.15 & 0.56 & -29.17 & -31.37 & ruminant adipose fat \\
\hline
\end{tabular}


